RAFAEL MING CHI SANTOS HSU

Motives for practice of physical activities: an evolutionary approach

SÃO PAULO

2022 


\section{Motives for practice of physical activities: an evolutionary approach}

Revised Version

Doctoral Dissertation presented to the Graduate

Program in Psychology at the Instituto de Psicologia da Universidade de São Paulo, Brazil in partial fulfillment of the requirements for the degree of Doctor of Philosophy.

Concentration Area: Experimental Psychology

Advisor: Prof. ${ }^{a}$ Dr. ${ }^{\text {a Jaroslava Varella Valentova }}$

SÃO PAULO

2022 
Hsu, Rafael Ming Chi Santos

Motives for practice of physical activities: an evolutionary approach / Rafael Ming Chi Santos Hsu; orientadora Jaroslava Varella Valentova. -- São Paulo, 2022.

$181 \mathrm{f}$.

Tese (Doutorado - Programa de Pós-Graduação em Psicologia Experimental) -Instituto de Psicologia, Universidade de São Paulo, 2022.

1. Motivation. 2. Physical Activity. 3. Sport . 4. Exercise. 5. Body/Movement Practice. I. Valentova, Jaroslava Varella, orient. II. Título. 
Name: Rafael Ming Chi Santos Hsu

Title: Motives for practice of physical activities: an evolutionary approach

Doctoral Dissertation presented to the Graduate Program in Psychology at the Instituto de Psicologia da Universidade de São Paulo, Brazil in partial fulfillment of the requirements for the degree of Doctor of Philosophy.

Approved in: 29/11/2021

Examination judges

Prof (a) Dr (a): $\quad$ Patrícia Izar Mauro

Institution: $\quad$ USP, Departamento de Psicologia Experimental

Judgement: APPROVED

Prof (a) $\operatorname{Dr}(\mathrm{a}): \quad$ Sandro Caramaschi

Institution: UNESP, Departamento de Psicologia

Judgement: APPROVED

Prof (a) Dr (a): $\quad$ Marcelo Fernandes da Costa

Institution: USP, Departamento de Psicologia Experimental

Judgement: $\quad$ APPROVED

Prof (a) $\operatorname{Dr}(a): \quad$ Michele Schultz Ramos

Institution: $\quad$ USP, Escola de Artes, Ciências e Humanidades

Judgement: APPROVED

Prof (a) $\operatorname{Dr}(\mathrm{a}): \quad$ Fernando Luiz Cardoso

Institution: $\quad$ UDESC, Departamento de Educação Física

Judgement: $\quad$ APPROVED 
This work is dedicated to my mother, Luciana Santos da Silva 
"Falar sobre nossa pesquisa é apresentar um pouco de nós mesmos"

Katia Rubio

"It is true that everything we wish for will not come to be...

But things that we must do must always begin with a wish"

Guy-sensei 


\section{PREFÁCIO (FOREWORD) E AGRADECIMENTOS (ACKNOWLEDGEMENTS) ${ }^{1}$}

Este trabalho começou em 2015, quando ainda era aluno de graduação em Educação Física e Saúde (antigo Ciências da Atividade Física), momento em que comecei a me preocupar com a necessidade de definir um tema para o Trabalho de Conclusão de Curso (TCC). Havia ingressado no grupo de pesquisa da Prof. ${ }^{a}$ Dr. ${ }^{\text {a }}$ Jaroslava Varella Valentova com o intuito de estudar o Comportamento Não Verbal. Entretanto, as circunstâncias não favoreciam a escolha por um caminho de pesquisa mais extenso em termos de coleta e análises, uma vez que se fazia necessário concluir o TCC dentro do prazo e sem conflito com as demais atividades que precisava desenvolver simultaneamente, como estágios e iniciação científica.

Assim, preparamos o projeto utilizando questionários, com inspiração no então recém publicado artigo de Marshall, Lefringhausen e Ferenczi $(2015)^{2}$, articulando temas como Motivações para prática de Atividades Físicas, Personalidade, Autoestima, Narcisismo, bem como Sociossexualidade, esta última uma das mais importantes linhas de pesquisa da orientadora.

O trabalho foi considerado de elevada qualidade, de modo que utilizamos apenas uma análise preliminar para o $\mathrm{TCC}^{3}$ (também devido ao escasso tempo), transformando o restante em um projeto de Mestrado, o qual foi submetido à Fapesp e ao Programa de Pós-Graduação em Psicologia Experimental do IP/USP. Recebemos uma avaliação positiva, com concessão de bolsa já na 1aㅡ tentativa, o que permitiu iniciar a Pós já em um regime de dedicação exclusiva à pesquisa. Ainda assim notamos que a quantidade de dados e a originalidade do projeto permitiriam buscar algo mais, pois o tempo de 2 anos ainda seria pequeno para analisar e publicar o que

\footnotetext{
${ }^{1}$ This section was kept in Portuguese, because some of the people acknowledged here cannot understand English.

2 Estudo focado nos diferentes motivos para uso do Facebook e sua relação com fatores de personalidade, autoestima e narcisismo. Buscamos um paralelo com atividade física por considerar que guardam entre si importantes semelhanças, como aspectos ligados à autoapresentação. Referência completa disponível no final da tese.

${ }^{3}$ Apresentado em forma de pôster e disponibilizado para acesso público em: < $\underline{\text { https://bit.ly/3iwJW7Z> }}$
} 
pretendíamos, de modo que solicitamos (e conseguimos) a passagem para Doutorado Direto ${ }^{4}$.

Com o prazo adicional, chegamos a ter planos de publicar a tese articulando 4 manuscritos submetidos do projeto como $1^{\circ}$ autor (portanto, além da exigência do programa, de 2 submissões, não necessariamente vinculadas ao projeto de Pós ou como $1^{\circ}$ autor), todavia os planos foram sendo revistos em função das circunstâncias que apareciam, devido a mudanças de prioridades, dentro da própria Pós (ex: focar em determinado artigo cujo escopo se encaixava ao chamado de um número especial internacional), ou por contingenciamento de metas devido à concorrência de atividades externas (como problemas familiares e o emprego a partir de 2019, tendo este último desencadeado um encerramento precoce da bolsa Fapesp, poucos meses após a conversão dos valores de Mestrado II para Doutorado I).

Desse modo, a presente tese ilustra um recorte do que foi possível priorizar mais ao longo dos últimos, apresentando os assuntos que conseguimos analisar e discutir com maior propriedade/profundidade, sendo relevante pontuar que os trabalhos seguiram em andamento até o último momento de depósito/defesa (mesmo com os requisitos mínimos para depósito já atingidos no início de 2021), na medida do possível, visando maximizar os necessários retornos à sociedade que financiou a realização desta pesquisa.

Quanto à disposição da tese em geral, conforme facultado pelo regimento do Programa de Pós-Graduação em Psicologia Experimental do IPUSP, optamos por adotar o formato de artigos como capítulos, os quais são precedidos e sucedidos, respectivamente, por seções de introdução e discussão geral. A figura abaixo ilustra um mapa conceitual contendo parte das principais ideias e conceitos que serão apresentados em maiores detalhes na parte textual ${ }^{5}$ :

\footnotetext{
${ }^{4}$ Caso haja interesse em relação a como era o projeto inicial, este encontra-se disponibilizado em sua última versão, aprovada pela Fapesp e pelo Programa de Pós na passagem para o Doutorado Direto, podendo ser consultado integralmente no endereço:

< https://drive.google.com/file/d/1hHvVr6Gy2zcJI9YapExC3RlhYqjupL2H/view?usp=sharing >

5 Vídeo da apresentação inicial da Defesa: $\underline{\text { https://youtu.be/Naje5nXqWMM }}$
} 
Pergunta Foco: o que Rafael gostaria de destacar sobre sua pesquisa de Doutorado?

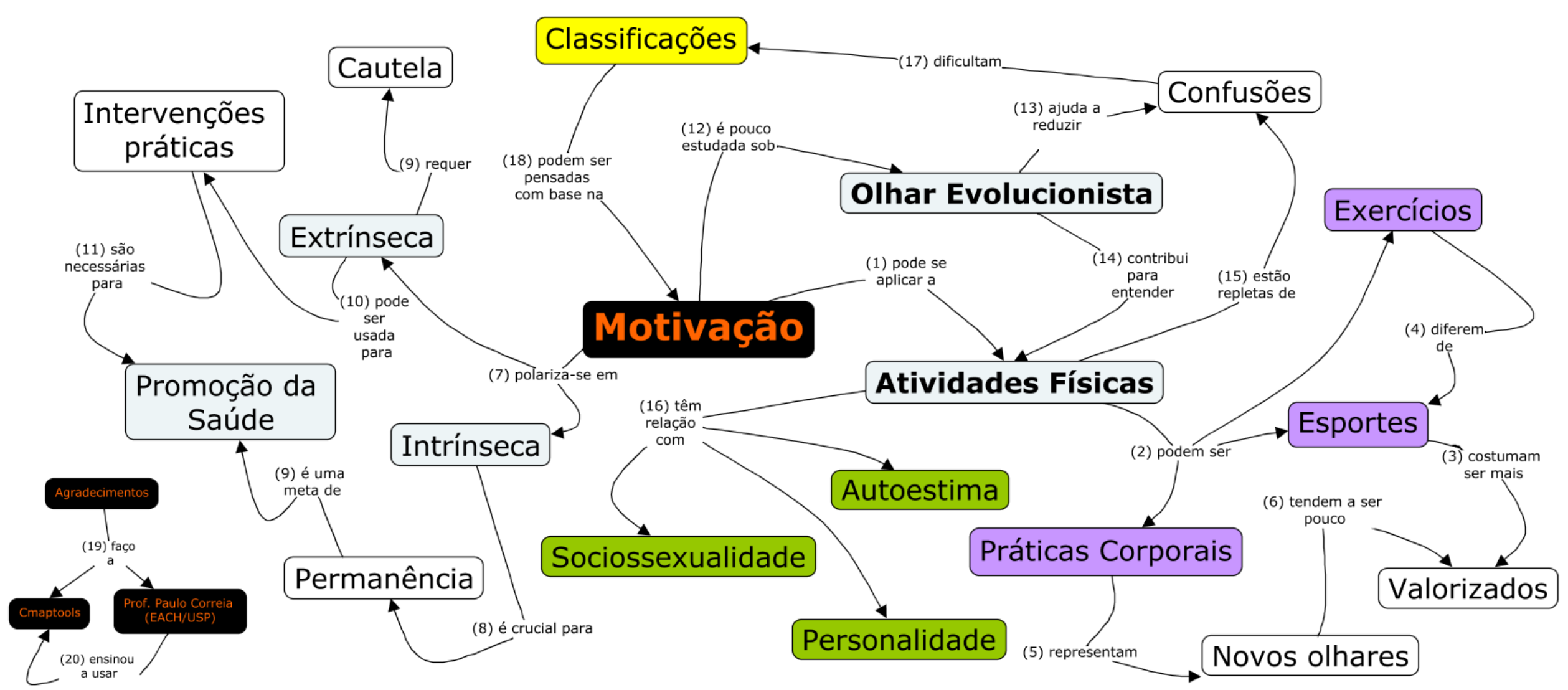


Tenho planos de manter as colaborações com a orientadora, através de PósDoutorado, para que nosso retorno à sociedade referente ao atual projeto seja expandido, bem como novos temas de interesse possam ser explorados formalmente.

Com o intuito de se valorizar esta trajetória, bem como de prestar contas à sociedade pelos valores que recebi durante os anos em que tive bolsa, segue uma relação das principais produções publicadas até a data de depósito, em ordem aproximada de importância (inicialmente por relevância pessoal, em seguida por fator de impacto e similares):

1- Artigo original do projeto, sobre motivações para prática de atividades físicas, publicado em 2020 na revista Psicologia USP6

2- Artigo em colaboração internacional sobre os motivos pelos quais pessoas solteiras consideram estar nessa condição, publicado em 2021 na revista Cross Cultural Psychology ${ }^{7}$

3- Artigo em colaboração internacional sobre primeiras impressões sobre diferentes pessoas, publicado em 2021 na revista Nature Human Behaviour?.

4- Capítulo de livro internacional sobre taxas de gêmeos no Brasil ${ }^{9}$.

5- Apresentação de poster em 2018 na XXIV Biannual Conference for Human Ethology- International Society for Human Ethology ${ }^{10}$

6- Apresentação de poster em 2019 no XXXVII Encontro Anual de Etologia Interações entre Animais, Sociedade e Ambiente ${ }^{11}$

\footnotetext{
${ }^{6}$ Hsu, R. M. C. S., \& Valentova, J. V. (2020). Motivation for different physical activities: a comparison among sports, exercises and body/movement practices. Psicologia USP, 31. Também disponível em: <https://bit.ly/3A11tew>.

${ }^{7}$ Apostolou, M., Birkás, B., da Silva, C. S. A., Esposito, G., Hsu, R. M. C. S., Jonason, P. K., ... \& Wang, Y. (2021). Reasons of Singles for Being Single: Evidence from Brazil, China, Czech Republic, Greece, Hungary, India, Japan and the UK. Cross-Cultural Research, 10693971211021816. Também disponível em: <https://bit.ly/3|3JZKf >.

8 Jones, B. C., DeBruine, L. M., Flake, J. K., Liuzza, M. T., Antfolk, J., Arinze, N. C., ... \& Sirota, M. (2021). To which world regions does the valence-dominance model of social perception apply? Nature human behaviour, 5(1), 159-169. Também disponível em: <https://bit.ly/3itchw7>.

9 Varella, M., Fernandes, E., Arantes, J., Acquaviva, T., Lucci, T., Hsu, R., ... \& Otta, E. (2018). Twinning as an evolved age-dependent physiological mechanism: Evidence from large Brazilian samples. In Multiple Pregnancy-New Challenges. IntechOpen. Também disponível em: $<$ https://bit.ly/2Y7CMzL>.

10 Trabalho disponível em: <https://bit.ly/3uCwDYy>.

${ }^{11}$ Trabalho disponível em: <https://bit.ly/3BennfS>.
} 
7- Apresentação de poster em 2019 no 3rd Brazilian Meeting on Evolution of Human Behavior ${ }^{12}$

8- Apresentação de poster em 2018, no XVII Congresso Brasileiro e $X$ Congresso Internacional de Psicologia do Esporte: Psicologia e a Busca da Excelência esportiva ${ }^{13}$

9- Orientação de poster apresentado no Minicongresso de Motivação e Emoção de $2019^{14}$

Além dos trabalhos mencionados e dos que integram a presente tese (publicados, submetidos ou em fase de finalização), com relação ao que ficou em velocidade reduzida e maior tempo de parada, também possuímos planos de retomada em momento oportuno: especificamente, oriundos do banco de dados remanescente da coleta principal realizada em 2016, bem como da iniciada em 2019 (versão elaborada com apoio de discentes orientados na monitoria da disciplina Motivação e Emoção do IPUSP, em que aprovei a oportunidade para testar uma versão compacta da coleta principal, corrigindo falhas e explorando preliminarmente possibilidades para potenciais colaborações futuras, tais como pós-doutorado, projeto jovem pesquisador, orientações formais de alunos, etc.

Independentemente do desfecho futuro, seguirão ocorrendo esforços para prestação de contas à sociedade do que se produziu com os valores investidos em minha formação. Para tanto, como iniciativa inicial, foi criada uma página de divulgação do projeto ${ }^{15}$

Gostaria de registrar meus agradecimentos às pessoas que foram importantes ao longo deste projeto, que se iniciou quando ainda cursava a graduação (justamente por isso, também vou acabar mencionando algumas das pessoas que foram importantes nesses momentos iniciais) em Educação Física e Saúde (antigo Ciências da Atividade Física) na EACH/USP ${ }^{16}$. Obviamente irei cometer algumas injustiças de

\footnotetext{
12Trabalho disponível em: <https://bit.ly/3B9u4zt>.

${ }^{13}$ Trabalho disponível em: < https://bit.ly/3D8jvxs $>$.

14 Trabalho disponível em: <https://bit.ly/3B6Pf5f $>$.

${ }^{15}<$ https://www.researchgate.net/project/Motivations-for-practice-of-physical-activities-and-personalityan-evolutionary-approach $>$.

${ }^{16}$ Importante destacar a contribuição institucional de ter iniciado a graduação em uma unidade de ensino inovadora, com um Ciclo Básico em que tínhamos aula com professores de diversas especialidades e lotados em outros cursos. Certamente as ideias conciliadoras e integradoras que constituem a presente tese também foram em alguma medida alimentadas por esse contato abrangente que tive em minha primeira graduação, pois quase sempre procurei aproveitar os ensinamentos recebidos.
} 
esquecer pessoas importantes, por limitações de memória, mas quero que todos/as que me ajudaram de alguma forma sintam-se reconhecidos/as. Por isso, já começo agradecendo a todas as pessoas que em algum momento de minha vida acreditaram em meu potencial e me incentivaram a seguir em frente, mesmo com minhas limitações.

Vou começar agradecendo aos/às participantes, que com suas respostas permitiram que o TCC e este Doutorado Direto pudessem ocorrer, sendo fundamentais, portanto, para os aprendizados aqui expostos (e além destes, muitos outros que inclusive levaram-me a reflexões que não conseguiria pensar sozinho e/ou que talvez não consiga incluir/aprofundar em alguma parte do texto, mas que são extremamente importantes, como os referentes às questões de etnias, religiões, etc...). Obrigado a todas as pessoas que tiveram a paciência de ir até o final, e especialmente às que me escreveram depois demonstrando interesse em saber mais, receber resultados, fazendo comentários... Muito obrigado também a todas as pessoas que repassaram minha solicitação de divulgação adiante, principalmente funcionários/as dos serviços de e-mails das instituições, em especial Edimeia e Dejanira da SAGA/PRG. Com toda a minha timidez, jamais esperava conseguir a contribuição de tantas pessoas em uma pesquisa minha!

Agradeço à minha orientadora, Profa. Dra. Jaroslava Varella Valentova (Jarka), uma pessoa sempre transparente e sincera. Sou-lhe imensamente grato por tudo, desde a aceitação como frequentador de seu grupo em 2015, com a posterior orientação do TCC, mesmo não sendo aluno do IP na época e vindo de uma graduação um pouco distante. Felizmente o trabalho ficou acima das expectativas e se transformou em mestrado, doutorado direto... o que certamente possui grande parcela de contribuição da Jarka! Agradeço também por toda a paciência em me aconselhar para a parte científica e acadêmica (por exemplo, incentivar a redação deste trabalho e dos artigos em inglês, mesmo sabendo que meu baixo domínio da escrita desse idioma lhe gerariam um imenso trabalho adicional de correção!), e mesmo para me ouvir e orientar sobre questões mais da vida em geral (incluindo desabafos ou perguntas bobas), que não fazem parte de suas funções formais. E claro, por toda a dedicação que tem a seu trabalho e aos alunos mesmo em momentos atípicos: por exemplo, ao longo da minha orientação, deixou de usufruir parcialmente de suas 2 licenças maternidade para corrigir meus trabalhos e treinar comigo as apresentações. Também agradeço pelos encorajamentos, sobretudo em momentos 
difíceis de baixa autoeficácia (ou problemas familiares), nos quais cheguei a duvidar da minha capacidade de chegar até aqui, pois durante boa parte do tempo fiquei bastante aquém do que considerava ideal. Raramente presenciei alguém ter um nível tão elevado como docente, pesquisadora e ser humano, e espero seguir me inspirando! Justa, compreensiva e incansável batalhadora para que as coisas funcionassem no nosso laboratório. Espero ter a oportunidade de continuar recebendo suas orientações em um pós-doutorado, apesar de não saber como será o futuro. Lamento que com todos os desafios, tenha ficado longe de deixar este trabalho à altura da pessoa que me orientou. Peço desculpas por ter sido em algumas vezes teimoso e rebelde... fico feliz que tenhamos sempre dialogado e conseguido solucionar as raras divergências que chegamos a ter.

Agradeço à minha família, principalmente Luciana e Leonisia (in memorian), que de seu modo lutaram bravamente para que eu tivesse condições de focar nos estudos até o final da graduação, sobretudo no momento mais difícil (depressão de 2015-16). Também agradeço aos demais membros e amigos/as que estiveram mais próximos sobretudo nos momentos de maior dificuldade. Se cheguei até aqui, vocês têm grande parcela nisso! Espero conseguir retribuir por tudo. Menção especial à Elenice Martiniano, a Nicão, sem a qual não teria sequer começado a estudar na faculdade, levando-me ao local em que foi aplicada a segunda fase da Fuvest (em uma época na qual era tímido demais para perguntar o caminho às pessoas, além de não possuir celular com GPS para planejamento de rotas em tempo real), e à minha mãe, Luciana Santos da Silva, que foi comigo no dia da matrícula na $\mathrm{EACH}$ e me incentivou desde o início, por exemplo, quando quis desistir do curso logo na $1^{\text {a }}$ semana de aula, quando fiquei triste por não conseguir me apresentar para a turma (além, obviamente, do constante exemplo de superação das adversidades, nunca desistindo da vida, por mais difíceis que tenham sido/estejam sendo as coisas. Sacrificou boa parte da vida pessoal e profissional para cuidar dos filhos, e depois de nossa Leonisia, até o final...). Apesar de eventuais conflitos, também preciso agradecer a meu pai e irmã (Tony e Angélica) por terem dado condições suficientes para que eu não precisasse conciliar a graduação com um emprego, maximizando assim os estudos e consequentemente me aperfeiçoando até ser capaz de elaborar projetos mais detalhados, capazes de conquistar as bolsas... Hoje sei bem: se desde o início tivesse que conciliar estudos e trabalho não teria conseguido chegar até esta etapa. Mesmo após tantos anos na linha "Etologia Humana e Comportamento Animal", 
por pouco não me esqueço da jovem sobrinha Rafaela, e das irmãs Gorda e ET (assim como demais gatos e cachorros que tive, in memoriam), exemplos constantes de motivação intrínseca para atividade física, principalmente no contexto da brincadeira!

Agradeço a Caio Graco Tieppo, que conheci inicialmente no tênis da USP através do amigo André Chinchio. Inicialmente, apenas jogávamos, mas com o tempo fomos fortalecendo nossa amizade. Deixo minha gratidão por ter estado disponível para conversar e me ajudar a encontrar soluções para problemas diversos, sobretudo pelas orientações/incentivos em momentos de incertezas e dificuldades, inclusive apresentando-me alternativas à carreira acadêmica e educação física (com as quais fui ficando menos esperançoso com o passar dos últimos anos), que até então via como únicas possibilidades existentes. Como bem disse o André, Caio não é um ser humano, mas sim um anjo! Espero no futuro seguir seu exemplo, não apenas no sucesso em concursos, mas também no principal: fazer o bem por onde passa! Nesse sentido de conversas sobre possibilidades após a pós-graduação, também sou muito grato ao Prof. Dr. Valério Almeida (que assim como outros professores, é exemplar no quesito de aliar uma postura profissional a boa relação com alunos, funcionários e demais pessoas do entorno. Agradeço também pelas oportunidades que me proporcionou de trabalhar em outras questões interessantes relacionadas à universidade com as quais normalmente não se tem contato).

Agradeço à Profa. Edvane Marlene Pires: quando nos conhecemos, apesar de estar tomando posse em um concurso disputado (e em uma época difícil de conseguir qualquer tipo de emprego), estava em um momento de baixa na vida pessoal e acadêmica. A senhora me ajudou a refletir sobre diversas possibilidades, a lembrar dos meus pontos fortes, superando assim a crença de que não seria capaz de terminar a tese dentro do prazo (no fim não precisei pedir prorrogação, nem mesmo a extraordinária devido à pandemia). Colocando os pensamentos em ordem, consegui me planejar melhor e fazer ajustes para que conseguisse conciliar as diversas exigências da vida que foram se somando. Aproveito e agradeço também às/aos todas/os demais psicólogas/os que me acompanharam ao longo dos últimos anos. Mesmo que por tempos variados de interação, muito me ensinaram, ajudando a suportar os momentos difíceis pelos quais passei durante a vida, em particular na graduação e pós: Kelly Sobral, Luiz e Soraya Bido, André Matias, Bárbara Sales, Aimeé Marcella, Andrés Antunez, Érika Colombo. 
À Prof. ${ }^{a}$ Dr. a Cristina Landgraf Lee, agradeço por todo o apoio, principalmente nos momentos iniciais da graduação (desde que nos conhecemos, no $2^{\circ}$ semestre de 2012), seja com aconselhamentos para começar a buscar ajuda pelas vias universitárias (com indicação de terapias, juntamente com a Profa. Dra. Patrícia Junqueira; auxílios na SAS, com as Assistentes Priscila Cintra, leda Reis e Psicólogo (na época estagiário) André Matias, e, posteriormente, a Psicóloga Kelly Sobral) e também por todas nossas reuniões e conversas inspiradoras. Mesmo não tendo me orientado formalmente, foi através de você que passei a ter mais interesse por Psicologia, em especial o desejo de estudar o comportamento não verbal (razão pela qual fui à palestra da IMELCO no IPUSP em 2015, ocasião em que conheci a Prof. ${ }^{\text {a }}$ Dr. ․ Emma Otta, que considero como o marco inicial de minha aproximação com a Pós). Agradeço à Cris também pela participação nas bancas de TCC e qualificação de mestrado, ocasiões nas quais recebi importantes e valiosas sugestões para aperfeiçoamento. Também por ter me proporcionado a oportunidade de ser monitor pela $1^{a}$ vez, mesmo sabendo das minhas limitações no quesito de comunicação (que na época eram bem maiores). Mesmo praticamente não tendo atuado profissionalmente com a educação física, só de ter sido seu aluno já valeu a pena ter feito o curso de CAF/EFS! Desejo ter oportunidades de manter contato e interações no futuro, além de muita saúde, para que possa continuar por muitos anos a formar pessoas com saber técnico/acadêmico, mas, acima de tudo, empatia e sensibilidade pelos outros.

À Profa. Dra. Michele Schultz Ramos, agradeço pela participação na banca de TCC, ocasião na qual recebi importantes sugestões para aperfeiçoamento nos projetos de mestrado e doutorado. E também pelo exemplo de pessoa e orientadora que foi (e segue sendo) para mim, com todo seu engajamento e persistência em lutar pelo que acredita, mesmo que quase sempre tendo que remar contra a maré (ex.: melhorias institucionais, combate às injustiças e status quo), o que certamente foi fundamental para que eu conseguisse chegar onde estou hoje; sou grato por todo 0 apoio, sobretudo nos momentos difíceis da graduação, sem o qual inclusive não teria forças para solicitar reconsideração da bolsa de IC, e, consequentemente, desistiria do fomento à pesquisa (não teria, assim, feito o pedido para a bolsa de mestrado da FAPESP ${ }^{17}$ ). E também pela compreensão pelo meu não envolvimento total na IC

\footnotetext{
17 Fundação que embora mereça muitas críticas pelo excesso de burocracia e por adotar um cruel e
} ultrapassado regime de dedicação exclusiva (incompatível com os valores de bolsa, sobretudo até o 
(aliás, aqui não poderia esquecer dos demais membros do Grupo de Estudos em Neurociências e Atividade Física, que na época foram fundamentais durante partes dos nossos experimentos que jamais seria capaz de fazer sozinho; sem essa ajuda, talvez não teria conseguido finalizar as burocracias da graduação a tempo de ingressar no mestrado). A ADUSP está em ótimas mãos!

Ao amigo Francisco Moraes (o Chicó), por todos os momentos de convivência e descontração! Agradeço também por ter organizado a palestra do IMELCO em 2015 no IP, pois sem isso, provavelmente minha aproximação com o IP (e, consequentemente com a Jarka) poderia ter demorado mais para acontecer (ou então, sequer ter ocorrido, já que participar nas disciplinas formalmente sempre foi algo muito complicado, devido à alta concorrência por poucas vagas e também às barreiras e entraves burocráticos do IPUSP). Como diz o grande Prof. Marcos Roberto (não poderia deixar de agradecer-Ihe também, assim como ao Prof. Thiago Luigi e Flávia Ferreira, que me receberam de braços abertos em seus excelentes cursos, mesmo não tendo condições na época de pagar por eles. Parte do meu interesse pela Psicologia Experimental certamente foi aumentando com o que aprendi com vocês!), desejo-Ihes "Sucesso Sempre"!

Agradeço ao Prof. Dr. Marco Varella, por ter observado importantes detalhes dos questionários, quando estávamos prestes a começar a divulgação, pelo convite para cursar sua disciplina logo ao ingressar na pós, oportunidade que proporcionou uma importante consolidação dos conceitos básicos e potencial ampliador de horizontes da abordagem evolucionista (e também me mostrar que pode ser divertido estudar um tema sobre o qual se tem um pouco de resistência pessoal- nunca pensei que seria interessante estudar a musicalidade! Foi, sem dúvida, uma das disciplinas que mais gostei na pós-graduação), e também pelas sugestões dadas de artigos, livros, e pelos valiosos comentários quando participava de alguma reunião em que discutia com a Jarka sobre o projeto, bem como por incentivar a participação em outras pesquisas e eventos (além, de ter reconhecido minha contribuição e me concedido coautoria no capítulo de livro sobre gêmeos, que foi minha primeira publicação no sistema de revisão por pares).

nível de mestrado para quem precisa sobreviver e ajudar a família em cidades com custo de vida cada vez mais elevado, como São Paulo), proporciona vantagens em relação às agências federais, como valores mais razoáveis de bolsas e reserva técnica, reajustados com maior frequência, ao contrário das federais, absurdamente congeladas há quase uma década). 
Agraadeço ao Prof. Dr. Fernando Luiz Cardoso, que viajou de Santa Catarina para participar presencialmente da qualificação (2019) e proporcionou diversas observações que contribuíram para expandir os horizontes de análise e interpretação de nossos dados, além de estar colaborando conosco na elaboração de novos artigos.

À Profa. Dra. Emma Otta, deixo minha gratidão, por ter me indicado o contato da Jarka em 2015, abrindo as portas para meu ingresso no IP. Agradeço também por ter intermediado contato com suas alunas Eloisa Fernandes (para indicação do artigo de autoestima) e Tania Lucci (que me ajudou com modelos para o comitê de ética). Além disso, por ter me aceitado em seu treino de pesquisa, através do qual conheci o grupo de pesquisa do Painel USP de Gêmeos, no qual pude aprender muito e também ter momentos de diversão durante os meses em que estive vinculado.

Aos/Às atuais e antigos participantes do grupo de pesquisa da Jarka, que sempre que possível, deram sugestões interessantes: Adriana Saavedra, Julia Creddo, Chicó, Marco e Jarka, que fizeram parte da versão piloto da pesquisa e permitiram importantes ajustes e correções, e, posteriormente, Renata de Felipe, Kamila Pereira, Silvio Augusto, Andréa Lorena, Chicó, Caio Silva, Natalia Anchieta, Anthonieta Mafra, Yago Moraes e, novamente, Jarka, que em variadas oportunidades fizeram importantes críticas e sugestões (e também aos que chegaram depois, com os quais terei maior possibilidade de interação quando acabar essa etapa corrida de depósito/defesa). Fica também a gratidão pela convivência e momentos de diversão que tivemos nas reuniões.

É importante também agradecer às professoras Dr. ${ }^{\text {a }}$ S do IPUSP me aceitaram como ouvinte em suas disciplinas (ainda na graduação), cujos conteúdos foram de grande ajuda para a confecção deste trabalho e para que conseguisse me preparar com mais segurança para o processo seletivo do PSE: Motivação e Emoção- Jarka, Briseida Resende e Emma Otta, Etologia- Vera Bussab e Patrícia Izar, Etologia do Ser Humano- Patrícia e Briseida.

Agradeço pelas oportunidades que tive, na Pós-Graduação, de apresentar partes do meu projeto e/ou desenvolver trabalhos com mais afinidade ao meu tema de pesquisa: disciplina de Atratividade e Sexualidade Humana da Jarka, disciplina de Etologia, dos Profs. Dr.s Nicolas Châline (deixo também o agradecimento pelo convite para conhecer a Comissão Coordenadora do Programa. Sempre tive interesse em conhecer como funcionam os bastidores, infelizmente com o emprego não consegui realizar o plano de me candidatar a RD do curso), Patrícia Izar (deixo também o 
agradecimento por ter me aceitado, juntamente com a Profa. Ronara Châline, como monitor PAE da disciplina de Etologia da graduação) e Emma Otta, e Preparação Pedagógica, do Prof. Dr. Marcelo Fernandes. Foram momentos fundamentais para que pudesse refletir mais profundamente e debater sobre meu trabalho. Esses espaços de aprimoramento foram fundamentais, já que na pós, disciplinas diretamente sobre os temas do meu projeto são extremamente escassas (particularmente, até a última vez que consultei o sistema Janus, não havia qualquer disciplina cadastrada com o termo "motivação" no nome, nem mesmo de curta duração).

Agradeço pela oportunidade que tive de ser monitor, em especial na disciplina Motivação e Emoção no ano de 2019, ministrada por Briseida e Nicolas, que aceitaram que eu apresentasse e desenvolvesse parte do meu projeto, mesmo este não fazendo parte da lista de opções que é tradicionalmente ofertada. Foi também meu último semestre em dedicação exclusiva (como bolsista), assim depois disso minha participação em geral nas questões da universidade passou a ser bem reduzida. Não poderia deixar de agradecer à equipe de discentes que escolheu o meu tema: Ana Berti, Jocicler Vieira, Lucas Weguelin, Pedro Moita, Stéphanie Tabata, Monami Takaoka e Rafael Ottolia. A escolha de vocês permitiu que eu tivesse a importante e rara experiência de ensinar e aprender com reuniões focadas em meu tema de pesquisa, o que dificilmente conseguia fazer em outros espaços.

Agradeço pelas oportunidades de acompanhar as lutas da universidade. Ainda que tenha em geral ficado distante das linhas de frente, tive alguns momentos de contribuição, juntamente com colegas que fizeram a iniciativa \#1MinutoDeCiência. Foi um importante gesto para mostrar a importância do que fazemos à sociedade, em um momento no qual os cortes nas verbas e bolsas aumentam cada vez mais.

Agradeço às/os professoras/es Drs. que aceitaram os convites para composição da banca de qualificação, em especial aos/às que deram devolutivas durante e após as bancas das 2 qualificações pelas quais fui avaliado: Cristina Landgraf Lee, Renata Pereira de Felipe, Fernando Luiz Cardoso, Patrícia Izar, Anthonieta Looman Mafra e Jaroslava Varella Valentova. Agradeço às/os professoras/es Drs. que fizeram parte da minha banca final (bancaconferência!) de defesa do Doutorado, pelas críticas construtivas, elogios, incentivos e por mostrarem diversos caminhos possíveis para continuidade e expansão deste projeto: Patrícia 
Izar, Sandro Caramaschi, Marcelo Costa, Michele Schultz, Fernando Cardoso e Jarka (que presidiu a sessão).

Também importantes para a passagem de Mestrado a Doutorado Direto foram os antigos representantes discentes: Rodrigo Lermes e Anderson Carneiro: obrigado pelas dicas que forneceram, pois nem sempre as informações estão claras no regimento da Pós...

Agradeço por todo o apoio institucional recebido. À Fundação de Amparo à Pesquisa do Estado de São Paulo (FAPESP), pela bolsa de Mestrado concedida Processo 2016/22964-0 (em convênio com a CAPES) e Bolsa de Doutorado DiretoProcesso 2018/13937-4. Fui bolsista de março de 2017 a novembro de 2019, totalizando 24 mensalidades recebidas de mestrado e 8 de doutorado. Embora a posse no emprego tenha me forçado a trocar essa remuneração por um salário líquido menor (pois levamos quase 2 anos até atingir o salário completo, com o acréscimo gradual dos poucos direitos que os servidores públicos da área ainda não perderam), justamente faltando poucos meses para entrar no DO-II, em que passaria a receber os melhores valores possíveis para o meu nível, fiz a escolha mais sensata, uma vez que não teria como garantir aprovação em concursos futuros (cada vez mais concorridos em tempos de desemprego recorde, enfraquecimento de direitos e certames cada vez mais escassos (o que só se agravou com as lamentáveis gestões frende a já severa pandemia de COVID-19), ao mesmo tempo em que só tinha garantido mais 1 ano de bolsa, com prorrogação incerta assim como dúvidas acerca de oportunidades futuras, dado o cenário crescente de cortes generalizados de verbas, em especial as de pesquisa). Enfim, apesar de ter continuado a receber como mestrado na maior parte do doutorado e não ter chegado à última faixa de bolsa, sou grato pois valores, mesmo não tendo sido os melhores possíveis, permitiram-me dar ajuda financeira à minha família, além de me proporcionar autonomia para me sustentar e caminhar com as próprias pernas.

Agradeço ${ }^{18}$ à Biblioteca do IPUSP, por facilitar a parte burocrática ao disponibilizar o formulário eletrônico de ficha catalográfica. Também aos atenciosos atendimentos recebidos na direção, secretarias de programas, comitê de ética,

\footnotetext{
${ }^{18}$ Embora recorde dos nomes de alguns funcionários, optei por mencionar as funções, pois várias pessoas me deram apoio importante mas não sei o nome para poder dar o merecido crédito... Como disse no começo, cometeria injustiças (esta devido à timidez para perguntar o nome de várias pessoas com as quais interagi por anos...)
} 
zeladoria, recepção, etc. E também, aos demais serviços da USP (bandejões, CEPEUSP, limpeza, bibliotecas, segurança, etc.), que me ajudaram a sobreviver na universidade, por mais deteriorados que foram ficando com as políticas de contenção de gastos (como congelamento de concursos e PIDV). Agradeço também à PRPG, que me disponibilizou acesso remoto à internet em um momento muito difícil para todos (Pandemia de COVID-19). E não poderia esquecer da equipe do Escritório de Saúde Mental da USP, coordenada pelo Prof. Dr. Andrés Antúnez, por ter me recebido em um momento no qual estava precisando de ajuda e com as contas no limite para acrescentar despesas, mesmo que fossem as de atendimentos a preço simbólico...

Apesar de não ser minha instituição, também sou grato à Charles University da República Tcheca e aos pesquisadores dela que continuaram a pagar a licença do software de questionários mesmo após a saída da Jarka, o que facilitou bastante o trabalho de coleta e preparação do banco de dados.

Agradeço às pessoas anônimas, que de alguma forma contribuíram com materiais que não havia na biblioteca ou em artigos, como altruístas que compartilham via internet arquivos que seriam impossíveis/muito difíceis de ser adquiridos por mim devido à minha condição financeira.

Agradeço às Prof. ${ }^{a}$ s Dr. ${ }^{\text {as}}$ s. Cristina Lee (disciplina de Psicologia do Esporte e do Exercício) e Katia Rubio (aceitou-me como ouvinte na disciplina de Dimensões Psicológicas da Educação Física) por possibilitarem contato com conhecimentos fundamentais da Psicologia das Atividades Físicas, o que certamente de alguma forma contribuiu para que o projeto ficasse mais robusto. Agradeço também ao Prof. Dr. Dante de Rose, com o qual embora quase não tenha interagido (pois já estava aposentado quando ingressei na graduação), doou diversos livros à biblioteca da $\mathrm{EACH}$, sendo muitos deles por mim consultados.

Agradeço a demais professores/as Dr.s que em algum momento da minha formação, direta ou indiretamente compartilharam conhecimentos e reflexões, muitas vezes em ocasiões pontuais, porém que ficaram na memória e, consequentemente, auxiliaram de algum modo na estruturação de importantes detalhes da presente pesquisa: Douglas Andrade, Yara Carvalho, Marília Velardi, Marcelo Massa, Soraia Saura e Ana Zimmermann, Luiz Dantas e Edson Manoel.

Quero também agradecer aos Prof.s Dr.s Cassio Meira, Fabiana Evangelista e Marcelo Massa, então titulares da comissão de TCC de EFS, por terem compreendido e aceitado minha solicitação para ser orientado por uma docente externa à EACH. Em 
especial, à Profa. Fabiana, também pelo exemplo de persistência, pois na mesma época em que minha proposta de Iniciação Científica foi rejeitada pela FAPESP, também teve uma solicitação à mesma agência indeferida. Recordo-me da sua fala: iria tentar de novo, quantas vezes fossem necessárias, até conseguir, o que foi inspirador para mim.

Para finalizar, não poderia deixar de agradecer às pessoas que ao longo dos últimos anos foram influenciando na minha própria motivação para praticar atividades físicas e assim manter estáveis minha saúde e rendimento acadêmico: amigos/as e colegas do tênis e demais atividades físicas que praticava principalmente no CEPEUSP, e também professores/as dessas modalidades. Foi um espeço em que pude conhecer pessoas das mais variadas categorias da USP (discentes atuais e egressos, docentes e demais servidores/as, comunidade externa, dependentes, etc.) e interagir bastante com todos/as, ao longo destes anos. Espero que consiga seguir frequentando o espaço ao longo das próximas décadas como fazem muitos de vocês.

Agradeço também aos meus supervisores de estágio da graduação, muito atenciosos, que me aceitaram em suas aulas, professores Thales Bon (aulas e Ranking de Tênis), Erica Takigahira (Pilates), Marcos Rojo (Yoga), Rosana Andreotti (programas de AF para portadores de Parkinson e AVC, coordenados pela Profa. Dra. Camila Torriani-Pasin), e, após formado, Flávio Marreti (pelo convite para acompanhar suas aulas de tênis e toda a convivência e ensinamentos, sobretudo em 2017). Permitiram que eu pudesse observar na prática aspectos relevantes da participação, que certamente se associam com as motivações para prática. E no "mundo do tênis", por ser minha modalidade favorita (ainda que não tenha conseguido realizar a meta de me inserir nesse campo profissional), também não poderia esquecer da importância que tiveram meus contatos com todos os capacitadores e colegas dos inúmeros cursos que participei, sobretudo Flávio Marreti, Suzana Silva, Eduardo Figueiredo, Caio Cortella, Cesar Kist e Daniel Rosenbaum.

Agradeço às pessoas que manifestaram interesse pelo meu projeto nas apresentações formais que fiz, evitando que ficasse plantado sem conversar com ninguém (que se somava à tristeza de estar longe de casa e outros apuros que passava sempre que viajava para locais desconhecidos, como me perder nos aeroportos ou cidades, mesmo com a tecnologia de hoje). Em particular, Prof.s Dr.s. Sandro Caramaschi, Fívia Lopes e Ana Maria Fernandez, no congresso de Brasília da HBES. 
Agradeço aos/às dezenas colegas e amigos/as do serviço nos diversos locais em que trabalhei (Ourinhos, Mogi Guaçu e São Paulo), em especial aos que me deram apoio em momentos diversos (principalmente Arnaldo Silva e José Dealis), sem os quais não teria conseguido terminar esta tese antes do prazo (pelo contrário, talvez seria necessário pedir prorrogação), pois morar sozinho demanda muito tempo com certos afazeres (dos quais só passei a ter plena consciência quando tive que me mudar para o interior, sem ter as condições financeiras para levar minha mãe e gatos ou para contratar serviços)...

Agradeço também aos professores da Acadepol que tiveram interesse pelo meu tema de pesquisa, em especial aos que me mostraram possíveis intersecções com a profissão: Edvane Pires, Marcos Vieira, Ricardo Fernandes e Tatiana Ferreira. Agradeço a todos/as demais colegas, chefes e docentes que me mostraram o quanto a nossa instituição pode ser humana, e, portanto, diferente do que boa parte do senso comum tende a pensar, ajudando que superasse também boa parte dos meus próprios medos.

Finalmente, registro também os agradecimentos a outras/os amigos/as e colegas (eles/as sabem quem são, pelo menos espero que sim!) que, diante dos mais diversos momentos, mandaram mensagens de apoio e/ou conversaram comigo, não me deixando tão isolado nessa acelerada sociedade contemporânea em tempos de redes sociais (que embora com suas vantagens, deixam as pessoas com vínculos muito superficiais e dificultam a formação de relacionamentos mais autênticos, afinal, na sociedade dos aplicativos de edição, tudo fica artificial e sempre parece haver outras pessoas mais interessantes para acompanhar/buscar vínculo). 


\section{ABSTRACT}

Hsu, R. M. C. S. (2022). Motives for practice of physical activities: an evolutionary approach. (Doctoral Dissertation). Instituto de Psicologia, Universidade de São Paulo, São Paulo.

Introduction: Motivation studies are key to foster behaviors that can be crucial to health, such as physical activity (PA). Despite its known benefits, a great proportion of the population does not practice PA regularly. One way to understand such an issue can be through an evolutionary analysis regarding motives for PA practice, which takes into account different priorities chosen by different participants. Some hypotheses focusing on survival value were proposed to explain sex differences in motivation for sports, such as Allying with Coalitions (more social motives in men) or Socialization (more appearance motives in women), however, there is a lack of evolutionary oriented studies analysing classification systems of PA. Previous classifications can be questioned because of lack of theoretical support or lack of statistical criteria. In addition, better understanding of how these variables are related may improve interventions regarding health promotion. Aims and Predictions: We aimed to explore individual differences in motives for practice of different types of physical activities and other related variables, through self-reported questionnaires. Specifically, we compared different PA classification systems according to 5 subscales of motivation for PA (Interest/Enjoyment, Competence, Appearance, Social, Fitness/Health) using 4 categories of PA (Individual Sports, Collective Sports, Exercises, Body/Movement Practices- Chapter One), and using previous authors categories, such as Motor Orientation (Water Practices, Rhythmicity, Combativeness) or no categories, i.e., a more data-driven approach (Chapter Two). We also tested if physically active participants differ from sedentary ones in personality (Big Five and self-esteem), sociosexuality and self-reported attractiveness and health (Chapter Three). We expected, for example, that motives for physical activity linked to appearance would be stronger in women, whilst motives linked to sociability would prevail in men. Regarding PA type, we expected a unique profile regarding Body/Movement Practices, showing a pattern of motives distinct to the well described Sports-Exercises dichotomy. 
Considering the categories of previous authors or the data-driven approach, we expected some emerging peculiarities that could boost discussion in the fields of Physical Education/Sports Sciences/Psychology of Physical Activities. Regarding personality and sociosexuality, we predicted that physically active participants would score higher on extraversion, conscientiousness, openness, self-esteem, self-rated attractiveness and health, sociosexual behavior and lower on neuroticism than sedentary participants. Materials and Methods: We recruited online more than 2,652 participants, mainly university undergraduates, who filled in a battery of questionnaires, including sociodemographic data, motives for physical activities, and measures of personality (Big Five, narcissism, self-esteem) and sexuality (sociossexuality). Main Results: Chapter One- We found main effects of type of PA in all motivation's subscales, and of sex on Interest/Enjoyment (higher scores in females). Exercises were the most extrinsically motivated (appearance and fitness/health), while Collective Sports (followed by Individual Sports) were the most intrinsically motivated (interest/enjoyment and competence), and also by sociability. Body/Movement Practices followed an intermediate pattern, generally closer (without significant differences) to Individual Sports compared to other types of PA. Chapter Two: we found that some PAs consistently separated themselves from others regarding motivational subscales. For example, Walking participants showed less Interest/Enjoyment and Competence than several other PAs. Pilates was highlighted by a particular low Social motivation in comparison to other PAs. Regarding the categories of previous authors, results mainly showed that different classification systems in general presented a similar distinction regarding most extrinsic and intrinsic motives. Chapter Three: we found significant more differences among females regarding personality (e.g., physically active women scored higher on extraversion, agreeableness and conscientiousness than sedentary), while among males on sociosexuality (physically active men scored higher than sedentary on both sociossexual attitude and behavior). Some variables showed a similar pattern for both sexes, such as physically active individuals scored higher than sedentary on self-rated health and self-esteem. Important effects of time of practice were noted. Discussion: Our three studies bring important contributions to the related fields, by providing initial evidence toward possible new methods of grouping PA types which can better inform interventions aimed to improve maintenance behavior, using motivation as a grouping factor. Also, important distinctions able to support interventions were found regarding physically 
active and sedentary regarding self-esteem, personality and sociosexuality, with specific differences according to sex, and time of practice. Conclusions: With our studies, we highlight some important implications regarding interventions in public health through promotion of PAs. Although several improvements can be made in future studies, our proposed classification- Physical activity divided into categories of Sports, Exercises or Body/Movement Practices is coherent, using the motivational oriented analysis. Our other studies also show the potential for further classification systems, and highlight the importance of paying attention to individual differences and types of motives. We further show a manner in which physical activities are related in domains central to human well-being, social interactions, and sexual life. More evolutionary and interdisciplinary based research on PAs is needed.

Key-Words: Motivation, Physical Activity, Sport, Exercise, Body/Movement Practice, Classification, Personality, Sociosexuality. 


\section{RESUMO}

Hsu, R. M. C. S. (2022). Motivos para prática de atividades físicas: uma abordagem evolucionista (Tese de Doutorado). Instituto de Psicologia, Universidade de São Paulo, São Paulo.

Introdução: Estudos motivacionais são cruciais para fomentar comportamentos que podem ser determinantes para a melhoria da saúde, como a prática de atividade física $(\mathrm{AF})$. Nota-se um contraste entre as evidências favoráveis à importância da prática de atividades físicas (AFs) e a alta prevalência de níveis insuficientes de envolvimento. Uma forma de entender melhor por que isso vem ocorrendo é através do acréscimo de uma perspectiva evolucionista voltada aos aspectos inerentes à motivação para prática, o que envolve levar em consideração diferentes prioridades estabelecidas por também distintos praticantes. Até esta data, a maior parte da escassa literatura evolucionista direcionada às AFs enfocava as diferenças entre os sexos nos esportes, destacando-se hipóteses de funções mais adaptativas, como a Aliança de Coalizões (motivos sociais maiores em homens) ou a das práticas de Socialização (motivos de aparência maiores nas mulheres). Nota-se em particular uma carência de estudos considerando a abordagem para analisar os atuais sistemas classificatórios de AFs, boa parte dos quais apresenta problemas de excesso de subjetividade, podendo ser questionados devido a insuficiente embasamento teórico ou estatístico. Além disso, uma melhor compreensão de como tais variáveis se relacionam é capaz de aperfeiçoar as intervenções voltadas à promoção da saúde. Objetivos e Hipóteses: A primeira parte deste trabalho (Capítulo Um) priorizou verificar possíveis influências do tipo de AF praticado em subescalas de motivação (Interesse/Prazer, Competência, Aparência, Social e Condicionamento/Saúde) usando 4 categorias de AFs (Esportes Individuais, Esportes Coletivos, Exercícios, Práticas Corporais). A segunda (Capítulo Dois) fez uma análise semelhante, empregando categorias propostas por autores anteriores, como Orientação Motora (Embatividade, Ritmicidade, Aquaticidade) ou sem categorização prévia (em outras palavras, uma abordagem mais indutiva, estatisticamente falando). Também foi explorado (Capítulo Três) se participantes fisicamente ativos (com a distinção de praticarem há mais de 6 meses- Manutenção, ou por 6 meses ou menos - Ação) apresentavam diferenças em relação aos 
sedentários em personalidade (Cinco Grandes fatores de personalidade), autoestima, sociossexuailidade e autoavaliações de saúde e atratividade. Esperava-se, por exemplo, que as motivações para prática ligadas à aparência seriam mais fortes em mulheres, enquanto as de sociabilidade prevaleceriam nos homens. Quanto ao tipo de $A F$, considerávamos encontrar um perfil diferenciado ao utilizar uma nova categoria- Práticas Corporais- em conjunto com mais tradicionais- Esportes e Exercícios. Quanto às categorias propostas pelos autores anteriores e a análise mais indutiva, esperávamos resultados com potencial de fomentar novas discussões aos campos da Educação Física/Ciências do Esporte/Psicologia das Atividades Físicas. Quanto a personalidade, sociossexualidade e demais fatores, esperava-se que os fisicamente ativos apresentassem maior extroversão, conscienciosidade, amabilidade, abertura, autoestima, comportamento sociossexual e menor neuroticismo em relação aos sedentários (com diferenças mais pronunciadas para os que praticam AF há mais tempo e também peculiaridades ao analisar cada sexo separadamente). Materiais e Métodos: Mais de 2652 participantes foram recrutados, os quais preencheram eletronicamente questionários sociodemográficos, de medição de participação e motivação para prática de AFs, variáveis de personalidade (Big Five, narcisismo, autoestima) e sexualidade (sociossexualidade). Resultados Principais: Capítulo Um- Encontraram-se efeitos principais do tipo de atividade física em todas as subescalas de motivação, e também do sexo (somente para Interesse/Prazer, maior para as mulheres). A categoria Exercícios foi a que apresentou maiores pontuações em motivações mais extrínsecas- aparência e saúde/condicionamento, enquanto os Esportes Coletivos (seguidos por Esportes Individuais) representaram os maiores escores nas motivações intrínsecas (interesse/prazer e competência), e também de sociabilidade. Por sua vez, as Práticas Corporais demonstraram um padrão intermediário, em geral mais próximo ao dos Esportes Individuais. Capítulo Dois: algumas AFs mostraram destaque em relação às demais. Por exemplo, praticantes de Caminhada apresentaram escores menores de Interesse/Prazer e Competência em relação a boa parte das outras modalidades. Já o Pilates diferenciouse por uma baixa motivação social. Por sua vez, a análise das categorias propostas em estudos anteriores mostrou um padrão, com um dos grupos sempre prevalecendo em relação aos demais em motivações intrínsecas e sociais, ou extrínsecas de Condicionamento/Saúde e Aparência. Capítulo Três: Para ambos os sexos, em algumas variáveis como Autoestima e saúde autorrelatada, notou-se um padrão no 
qual os participantes regulares de AFs (há mais de 6 meses) diferiram dos sedentários. Outros fatores apresentaram efeitos mais pronunciados apenas para determinado sexo, tais como mulheres ativas em manutenção pontuando mais do que sedentárias em extroversão e conscienciosidade, enquanto, para homens, maior sociossexualidade nos que praticavam há mais tempo em relação aos sedentários. Discussão: Os três artigos trazem contribuições importantes, pois acrescentam evidências favoráveis à criação de novas possibilidades de categorizar os tipos de AF, e assim melhor instruir intervenções direcionadas à promoção de saúde via manutenção da prática, usando as subescalas de motivação como fatores de agrupamento. Além disso, importantes peculiaridades foram notadas com relação aos fisicamente ativos e sedentários quanto a autoestima, sociossexualidade e personalidade, com resultados específicos de acordo com o sexo e/ou tempo de prática. Conclusões: Até o presente momento, os resultados encontrados podem sugerir importantes implicações às políticas e/ou intervenções ligadas à saúde pública via promoção de AFs. Apesar das limitações existentes, o sistema de classificação proposto- Atividade Física dividindo-se em Esportes, Exercícios e Práticas Corporais mostrou coerência, sobretudo no formato adotado- análise mais orientada às motivações, apresentando potencial de aperfeiçoamento futuro, com base nas demais análises. Novas classificações e intervenções práticas poderão ser elaboradas também levando em consideração variáveis ligadas às diferenças individuais, tais como personalidade, sociossexualidade e histórico prévio com as AFs. Juntos, os estudos que compõem esta pesquisa evidenciam maneiras através das quais as atividades físicas podem se relacionar com aspectos centrais da vida humana, bemestar, interações sociais e sexualidade. Mais pesquisas com orientação evolucionista e interdisciplinar articulando esses tópicos (e acrescentando outros) são necessárias.

Palavras Chave: Motivação, Atividade Física, Esporte, Exercício, Prática Corporal, Classificação, Personalidade, Sociossexualidade. 


\section{SUMMARY}

INTRODUCTION

MOTIVATION

Factors influencing motivation

EVOLUTIONARY HUMAN SCIENCES

4

Causation

Ontogeny

Phylogenesis

Adaptive Functions

The Updated Pyramid of Needs/Motivational Systems

Immediate Physiological Needs

Self-Protection

Affiliation

Esteem/status

Mate acquisition

Mate retention

Parenting

Sex Differences in motives for PA

Allying with Coalitions

Spectator Lek

Development of Skills

Courtship Display

Socialization

Important observations

Age Differences in motives for PA

PHYSICAL ACTIVITY

Definitions

Physical Activity 
Sport

Exercise

Body/Movement Practice

Other classification systems related to PA

Positive and Negative Outcomes of PA

PERSONALITY

Five Factors Model of personality (Big Five)

Self-esteem

Narcissism

Personality and PA

SEXUALITY AND SOCIOSEXUALITY

ADDITIONAL JUSTIFICATIONS TO STUDY MOTIVATION FOR PA, AND ASSOCIATED FACTORS

AIMS AND PREDICTIONS

AIMS

HYPOTHESES/PREDICTIONS

MATERIALS AND METHODS

RESEARCH DESCRIPTION

SAMPLING PROCEDURES

INSTRUMENTS

Sociodemographic questionnaire

Practice of PA

Short Questionnaire to Assess Health-enhancing Physical Activity

Motivation for physical activity measure revised

Sociosexual Orientation Inventory Revised

Rosenberg's Self-Esteem Scale 
Reduced Scale of Personality Descriptors (RED5)

STATISTICAL ANALYSES

SOCIODEMOGRAPHIC CHARACTERISTICS OF

PARTICIPANTS

AGE RANGE

WEIGHT AND HEIGHT

RELIGION

RACE/COLOR/ETHNICITY

EDUCATION

MARITAL STATUS

SEXUAL ORIENTATION

CLASSIFICATION ACCORDING TO TIME OF PRACTICE

CHAPTER ONE- MOTIVATION FOR DIFFERENT

PHYSICAL ACTIVITIES: A COMPARISON AMONG SPORTS, EXERCISES AND BODY PRACTICES

ABSTRACT

INTRODUCTION

Aims and Hypothesis of the current study

METHODS

Participants

Procedure

Statistical Analyzes

RESULTS

Effect of type of physical activity, sex and age on motivation for physical activity

Differences in self-reported practice of PA among sexes and Relations between Age and Type of PA

DISCUSSION AND CONCLUSIONS

ACKNOWLEDGEMENTS 


\section{REFERENCES}

CHAPTER TWO - COMPARING DIFFERENT TYPOLOGIES

OF PHYSICAL ACTIVITIES WITH FOCUS ON MOTIVATION
ABSTRACT
INTRODUCTION
METHODS
Participants
Instruments
Procedure
Statistical Analyses
RESULTS

Effect of Complexity-Organization on motives for physical activity Effect of Number of Participants in each activity on motivation for physical activity

Effect of predominant Physiological Demand on motivation for physical activity

Effect of Intensity of Energy Expenditure on motivation for physical activity

Effect of Motor Orientation on motivation for physical activity

Effects of using no categories of physical activity on subscales of motivation

DISCUSSION

ACKNOWLEDGEMENTS

REFERENCES

CHAPTER THREE (DRAFT)- BIG FIVE, SELF-ESTEEM, AND SOCIOSEXUALITY AS PREDICTORS OF PARTICIPATION IN PHYSICAL ACTIVITIES

ABSTRACT

INTRODUCTION

Aims and Hypothesis of the current study

METHODS 
Participants

Instruments

Procedure

Statistical Analyses

RESULTS AND DISCUSSION

Effects of group of PA on Big Five, self-esteem, sociosexuality and self-evaluations among men

Effects of group of PA on Big Five, self-esteem, sociosexuality and self-evaluations among women

DISCUSSION

ACKNOWLEDGEMENTS

REFERENCES

GENERAL DISCUSSION

MOTIVATION AND PRACTICE OF PHYSICAL ACTIVITY

CLASSIFICATION OF PHYSICAL ACTIVITIES

INSTRUMENTS AND PROCEDURES

SAMPLE AND FUTURE DIRECTIONS

ADDITIONAL LIMITATIONS AND POTENTIALITIES

FINAL CONSIDERATIONS

REFERENCES

APPENDIX 1- INFORMED CONSENT TERM

APPENDIX 2- SOCIODEMOGRAPHIC QUESTIONNAIRE

APPENDIX 3- TRANSLATED AND ADAPTED SHORT QUESTIONNAIRE TO ASSESS HEALTH-ENHANCING PHYSICAL ACTIVITY (SQUASH)

APPENDIX 4- NARCISSISTIC PERSONALITY (13 ITEMS)

APPENDIX 5- TRANSLATED VERSION OF MOTIVATION FOR PHYSICAL ACTIVITY MEASURE- REVISED 
APPENDIX 6- SOCIOSEXUAL ORIENTATION INVENTORY- TRANSLATED VERSION

APPENDIX 7- BRAZILIAN VERSION OF ROSENBERG'S SELF-ESTEEM SCALE

APPENDIX 8- REDUCED SCALE OF PERSONALITY DESCRIPTORS (RED5) 


\section{INTRODUCTION}

In a context in which sedentary lifestyle is highly prevalent, some questions regarding physical activity (PA) practice are: why do people practice PA? What make some to prefer one activity but not another? Are there sex or age differences in preferences and practices of PA? What makes some persons keep or start practicing PA even under extreme conditions, such as during pandemics?

With the present work we expect to raise such questions, in a Brazilian sample, by exploring different motives for practicing PA. The present research adds evolutionary theoretical background to explain this human behavior. Evolutionary perspective has been rarely applied to analyze the psychology of physical activities. Some of the recent researchers who have made this link are: Apostolou and Lambrianou (2017); Deaner, Balish and Lombardo (2015); Balish, Eys and SchulteHostedde (2013); Rosa et al., (2015); Lee-Manoel (2002).

The present dissertation is structured on a general introduction, followed by a set of manuscripts (chapters), and, finally, a general discussion and conclusion. With regard to organization of the introduction, we start with a general conceptualization of terms, followed by a focus on more specific topics, related to the aims of the research, seeking to articulate them, as possible, within the frame of evolutionary perspective, and also other important approaches, trying to maintain an interdisciplinary dialogue.

As will be explained throughout this introduction, we suggest that a better understanding of motives for PA practice is a key to successful implementation of health promotion programs.

\section{MOTIVATION}

Motivation is defined according to degrees of wanting, wishes and aspirations (Baumeister, 2016; Reeve, 2018; Ryan \& Deci, 2000b), and is characterized in terms of direction and intensity/effort (Sage, 1977, as cited by Weinberg \& Gould, 2018; Reeve, 2018). Direction involves decision making, seeking and attraction, whereas energy is the management of the applied effort (Reeve, 2018; Weinberg \& Gould, 2018). Motivation is also suggested as a set of processes able to influence causation of behavior (Ades, 1980/2018).

Motivation can be integrated with most psychological topics, because the causal chain to several behaviors begins with motivation (Baumeister, 2016). Also, 
motivation is influenced by environment, and can be a complex and multifaceted phenomenon (Baumeister, 2006; Reeve, 2018; Weinberg \& Gould, 2018). It can be understood as a game in which the organism takes circumstances into account aiming for the best advantage (Ades, 1985/2020). The complexity of motivation is elevated, because "the causes of human behavior evade any simple explanation or prescription" (Wlodkowski, 2008).

Baumeister (2016) proposes that although human motivation shares some aspects with other animal species, it also has some peculiarities. Motivation can be understood as a central dimension to behavior, because an array of other processes are directly linked to it, or are derived from it. Moreover, motivation has an evolutionary importance, since it leads and prepare the organism to behaviors crucial to survival and reproduction (Baumeister, 2016; Reeve, 2018).

As a research field, according to César Ades (1980/2018) motivation is, simultaneously, a promising and neglected field, filled with several controversies and confusions.

Research in motivation focuses on why we want and why we do some things, and on behavioral expressions of motivation, such as: effort, latency, persistence, choice, probability of response and body language (Reeve, 2018). Two fundamental questions regarding motivation are: what causes behavior, and why it varies in intensity (Reeve, 2018).

Motivated behavior is as a combination of internal variables, such as curiosity, plus interacting environmental inputs able to originate, maintain, reward or inhibit behavior (Ades, 1980/2018).

According to Reeve (2018), motivation is mainly expressed and measured according to criteria of: behavior, self-report, engagement, psychophysiology and brain activations. Here we focus on self-report via questionnaires.

Regarding PA, the analysis of participatory motives is a first step in examining what engage and maintain individuals doing PA (Larsen et al., 2021). Ryan and Deci (2000b, 1985) Self-Determination Theory (SDT) has guided most of the existing research in behavior change (Rosa et al., 2015). It is based on the fundamental distinction among amotivation, intrinsic, and extrinsic motives, following the definitions (e.g., Ryan \& Deci, 2000b, Balbinotti \& Barbosa, 2009; Ryan et al. 1997; Matias, 2019; Reeve, 2018): 
a) Amotivation corresponds to a context in which a person is lacking intention to do some tasks, even if this task is among a set of routine activities. They may not act at all, or act without intent. A possible extreme example of amotivation can be burnout in an athlete's or coach's career.

b) Extrinsic Motivation is composed by a subset of regulatory styles that vary from external regulation (behavior is regulated by material rewards or looking to satisfy an external demand), introjected regulation (action occurs after internalizing an external motivational source, in which the individual performs the activity to avoid negative emotions and is not fully experienced as part of the self), identified regulation (when the individual recognizes the importance of activity and consciously values it), and integrated regulation (occurs when identified regulations are fully assimilated, being almost intrinsic). The progress in this continuum is dependent on the degree of autonomy and subject's information processing skills. Examples of extrinsic motives can be doing a PA for reasons, such as appearance improvement, fitness or health enhancement, and socialization.

c) Intrinsic Motivation means that the aim and achievement of something originate within the own individual, making possible to extract pleasurable sensations from the action itself. Also, intrinsic motivation is a state positively related with psychological well-being, interest, joy and achievement disposition. It contains 3 aims: motivation to know (when there is an intent to learn), motivation to achieve (when something is done for the enjoyment of execution), and motivation to experience (to experience stimuli inherent to the task). Intrinsic motivation can be strengthened by social-contextual factors that conduce to feelings of positive perception of competence, autonomy and relatedness. Examples of intrinsic motives can be doing a PA for reasons such as interest or enjoyment, and strengthening perception of competence.

Importantly, these concepts are not completely independent, since intrinsic and extrinsic motivation can interplay, so that intrinsic motivation predominates in seeking opportunities, while extrinsic motivation is more common in avoiding threats (Ades, 1980/2018). Regarding behavior change, maintenance of change is dependent on the degrees of interaction between these different regulations (Matias, 2019). Despite this, intrinsic rewards have the advantage to motivate behavior even in the absence of biological deficits or extrinsic rewards/punishments (Heckhausen \& Heckhausen, 2018) 
Studies inspired by Self Determination Theory (e.g., Frederick \& Ryan, 1993, Ryan et al, 1997) showed that aspects of intrinsic motivation are more positively correlated with important outcomes of PA, such as participation measures (e.g., weekly frequency of practice, energy expenditure and workouts duration) and adherence.

\section{Factors influencing motivation}

A wide array of factors can influence motivation, such as personality, environment, evolutionary mechanisms, etc. For example, social environment can influence motivational climate. Thus, teacher's attitude can be an important factor influencing individual motivation (e.g., Serrano et al., 2017).

There are several environmental and/or personal barriers to PA practice. For example, many individuals have a work journey that frequently surpasses 40-44 hours per week, thus having little time left for PA practice. The remaining time is scarce and is disputed by conflicting values, behaviors, and attitudes (Matias, 2019). Some examples of possible needs that cause interferences are family, friends, rest, study, etc. In this sense, even other motives can be added in this equation, because they cannot always be satisfied simultaneously with PA practice, thus forcing the individual to create priorities: for example, to invest in romantic relationships, study, work, eat, sleep.

Considering the existence of more than 20 theories about motivation (Reeve, 2018), it is beyond the scope of this thesis to present and recur to all of them. Therefore, we will prioritize some approaches, such as Renovated Pyramid of Needs (Kenrick et al., 2010) and Self Determination (Ryan \& Deci, 2000b).

Evolutionary Human Sciences and its relations with motives for doing PA are outlined in the next sections.

\section{EVOLUTIONARY HUMAN SCIENCES ${ }^{1}$}

\footnotetext{
${ }^{1}$ We opted to use this broader term as an alternative to more famous and discussed ones, such as Evolutionary Psychology or Human Ethology. However, important ideas, concepts and theories from such approaches will be cited here, thus integrating them into the broader term "Evolutionary Human Sciences".
} 
Evolutionary Human Sciences (EHS) can be defined as a set of recent metatheoretical paradigms of science that aim to integrate knowledge of evolutionary biology and modern psychology (mainly cognitive) avoiding hierarchies, allowing, then, a crossed epistemology which favors interdisciplinarity (Ades, 2009; Balish, Eys \& Schulte-Hostedde, 2013; Buss, 2009; Crawford \& Krebs, 2008). In this sense, EHS aim to investigate questions traditionally addressed by more classic fields of Psychology and other sciences, contributing to traditional approaches with a more evolutionary emphasis. Evolutionary approaches also highlight the importance of understanding both positive and negative aspects of human behavior (Kenrick et al., 2010).

EHS frequently adopts a comparative approach, confronting similarities and differences between humans and other animals, emphasizing, simultaneously, form and function, distinguishing causal and functional/proximate and ultimate categories (Alcock, 2011; Ades, 2009). In other words, the comparative approach allows "use of data from one species to suggest lines of research in others, while at the same time never neglecting species differences" (Hinde, 1991). Also, evolutionary approach takes into account spontaneous motivational processes throughout lifespan (Ades, 1985/2018).

These latter specificities are derived from classical Ethology, which was the first discipline to formalize the study of behavior under the Darwinian evolutionary optic (Izar, 2009). Ades (2009) highlights some of the insights of Ethology: the aim to search for instinctive roots to understand behavior, and also the use of naturalistic observation.

As cited by several authors (e.g. Balish, et al., 2013; Ferreira, 2011; Izar, 2009, 2018; Kenrick et al., 2010), one of the most important reasoning of classical Ethology was to explain why some behavior happens based on the following four questions/explanations placed on time and place axes ${ }^{2}$ systemized by Tinbergen (1963):

1) the most immediate cause (causation), which can be explained through physiological, neural, motivational mechanisms and its relation with current environment;

\footnotetext{
2 This later proposal of naming- time axes of causation or explanation- was proposed by lzar (2017), on a graduate class of Ethology, to avoid inappropriate hierarchies that could be result from the use of "levels". For a complete review regarding this, see Varella (2018).
} 
2) the factors responsible for development of the behavior throughout the lifespan (ontogenesis), including long-term effects of causation mechanisms;

3) the evolutionary history (phylogenesis), which involves comparison with other species, and;

4) adaptive function (survival value), aimed to understand its past and current utility and why it was selected.

The four questions are not only relevant for science, but also for education and applications in daily life (O'Brien \& Gallup, 2011).

An evolutionary approach to motivation contributes to understanding behavior as a result of several determinants (Ades, 1985/2018). In this sense, regarding the main topic of the present study, Motivation for PA practice, the four questions can be employed to provide a closer analysis, and as such, a better understanding about this phenomenon.

Although it is out of the present work's scope (and probably a great part of all other research) to focus on all 4 questions simultaneously, their analysis can be valuable. Including at least a minimal knowledge of Ethological explanation questions provides a more complete understanding of the studied phenomena (Dawkins,1989, as cited in Ferreira, 2011).

\section{Causation}

The mechanical cause of motives for doing a PA can be related to physiological and neural mechanisms that trigger preparatory and consuming behaviors related to PA. Also, causation involves variation in motivational priorities according to immediate contextual cues (Kenrick et al., 2010). For example, intrinsic motivation, very important for adherence to PA (Ryan et al., 1997), is related to activations in brain areas, such as left caudate and parahippocampal gyri (Di Domenico \& Ryan, 2017). Another example can be the genetics relations with PA: individuals with at least one copy of the met allele for Brain Derived Neurotrophic Factor (BDNF) presented increased levels of intrinsic motivation in comparison to their counterparts (Caldwell Hooper, Bryan \& Hagger, 2014).

Causation also includes immediate triggers responsible for guiding PA practice, such as observed pleasure and joy, cognitive evaluations, such as costs $\mathrm{x}$ benefits analysis (e.g.: the energetic costs required for practice and posterior health benefits). Another aspect influencing PA can be availability of opportunities for PA practice, such 
as squares, clubs, parks, etc. Specific environmental pressures and barriers, such as family, friends and current cultural influences, can also be entailed in this more immediate time scale.

\section{Ontogeny}

According to Hinde (as cited by Bateson,1991), a large number of influences affect the outcome of development. For example, past experiences have a great potential to modulate the value of motivationally important incentives (Ades, 1985/2018).

It is known that PA are influenced by long term experiences (at individual's life time), that may be reflected in the current pattern of practice of PA. For example, a person who was obligated by parents to do PA or who was neglected/rejected by peers because lack of skills can later be traumatized and avoid some specific activity or PA in general, and can even suppress the recognition of the health benefits. Another aspect that influences PA motivation within the developmental stage is individual lifehistory (Kenrick et al., 2010). Thus, PA may become less or more important according to its interaction with other motivational needs and priorities that can change during lifetime.

Further, other long-term contextual events may influence behavior, plans or other motivational dimensions, such as competence perception. More specifically, life stage, hormonal levels (Caldwell, 2016), deprivation, or culture can influence PA behaviors and motivations. For example, more extreme patriarchal cultures, in which women obligatorily wear long clothes, may act as a barrier to PA practice. In addition, a study on a cohort of identical monozygotic twins discordant for 30 years in engagement in PA showed that there were significant differences in motives to practice PA when comparing the active twins with their sedentary co-twins, such as greater scores for the physically active regarding enjoyment, affiliation and mastery (Aaltonen et al., 2012). That is, despite starting with the same genome, each co-twin can have a unique interaction with the environment (mostly non-familial), thus reaching different outcomes regarding PA behavior.

\section{Phylogenesis}


Indirect evidences about PA can be valuable tools to comprehend ancestral environment, and thus, a valuable way to infer about evolution of motivational properties.

Attempting to explain sedentary behavior from evolutionary approach, Caldwell (2016) reviewed several studies regarding energy expenditure in different human populations and also in other animals. One of the presented hypotheses is that allocation of energy across lifespan was shaped to maximize reproductive success. For example, women in many societies invest more in child care (frequently several offspring simultaneously), activities calorically and time expensive (Caldwell, 2016).

The previously presented elucubrations can help to estimate and/or expand important aspects that can be connected to predominantly proximate level theories, such as Self-Determination Theory. For example, we can speculate in which moment of evolutionary history did extrinsic motivations emerge; or when did people start to consciously practice PA aiming to appearance change; or whether it is a human peculiarity.

One way to start such analyses can be by looking, comparatively, at similarities and differences in relation to more classic topics of ethological research, such as Play and Attachment. For example, as cited by Di Domenico and Ryan (2017), the Affective Neuroscience of Jaak Panksepp (e.g., 1998) and Harry Harlow's (e.g., 1958) studies on social isolation in monkeys involve non-human equivalents of intrinsic motivations. Harlow was the first to conduct experimental research regarding intrinsic motivationusing non-human animals (Di Domenico \& Ryan, 2017). Research by Panksepp and colleagues suggest a SEEKING system guiding foraging and exploratory activities, working as an objectless appetitive system (Di Domenico \& Ryan, 2017). In addition, some studies by Harlow (1958) showed a scenario suggestive of motivational interaction (between attachment and SEEKING): when exposed to an open field test, isolated monkeys vary in exploratory behavior depending on the presence or absence of the mother surrogate. In other words, physically active behaviors were more prevalent under experimental conditions associated with more positive affective states.

\section{Adaptive Functions}


Being motivated, either intrinsically or extrinsically, to do PA has its clear survival value. They have been directly (e.g., surviving after running from a predator) or indirectly (e.g., having high levels of positive feelings during and after playing) linked to important outcomes leading to survival and reproduction compared to staying amotivated.

Through body movement, animals can meet several goals essential to survival, such as displacement, foraging and processing food, competing with rivals, facilitation of social interactions with partners and potential mates, caring for relatives, protection against danger, communication, etc. (Caldwell, 2016; Bortz, 1984; Lee-Manoel, 2002; Von Frisch, 1974). In relation to food search, Bortz (1984) emphasizes the cyclic relation between nutrition (especially meat consumption) and kinesiologic adaptations, in which they served one another, contributing to some peculiarities of our species, such as the big brain development and adapting to diverse environments.

Regarding social interactions, Lee-Manoel (2002) points that very often PA provides possibilities of social integration, reflections about feelings and intentions, and thus can lead to broadening of self-knowledge. PA is thus crucial from the evolutionary perspective, since the needs to belong and attachment can be considered as part of affiliation, a fundamental human need (Baumesteir \& Leary, 1995; Bowlby, 1981; Kenrick, Griskevicius, Neuberg \& Schaller, 2010).

One of the functions of motivation is to enable approach to or avoidance of specific options within a broader context through specific actions (Baumeister, 2016). So, functions of different motives for doing PA can vary according to the specific type of PA (and specific situation in which it was) being performed. For example, a running activity could be predominantly extrinsic or intrinsic based on the situation in which it was performed: in a situation of play would prevail intrinsic motivation (e.g., an aim to have enjoyment), whereas in the situation of running from a predator would prevail extrinsic motives (such as looking for safety). In general, to run away from a predator is not as enjoyable as playing, although exceptions may exist, when the prey seems to be "confident" about its abilities to run away from the predator (see FitzGibbon \& Fanshawe, 1988). The authors discuss that the gazelle's stotting behavior can function as an honest signal of physical condition, which in turn can contribute to survival by inducing the predators to go after another prey.

Thus, the functional evolutionary perspective suggests that possible influences regarding PA type correspond to different challenges/opportunities faced by the 
species, also interacting with its relative degree of autonomy, or predominant type of motivation and emotion involved.

A similar reasoning can be applied to sex differences in motivation for doing PA. Even unconsciously the sexes can be differently predisposed or conditioned to participate and/or being more motivated for doing some PA more than others, according to the specific PA similarity relative to more ancestral ones. For example, men engaged more in hunt activities in ancestral environments, so it would be expected them to find similar contemporary activities (such as fishing) as more enjoyable than women, as the opposite would be seen regarding gathering PA (Apostolou \& Shialos, 2017).

\section{The Updated Pyramid of Needs/Motivational Systems}

Another evolutionary theory of motivation that can be applied to PA practice is the Renovated Pyramid of Needs (Kenrick et al., 2010), which explores human motives as structured in a hierarchic pyramid.

The pyramid is an updated version of the original theory by Abraham Maslow (1943), and is composed of several motivational systems in the order they are presumed to emerge developmentally (Kenrick et al., 2010). Each motivational system is connected to some threats and opportunities, and serves adaptive goals. The Renovated Pyramid of Needs is strongly based on Life History Theory and includes aspects of sexuality, including reproduction, in greater detail (Kenrick et al., 2010).

Based on the general concepts presented by Kenrick et al. (2010), all of these stages can be related to PA practice directly or indirectly, and thus are probably connected with motives for doing PA, as follow (see, also, figure): 


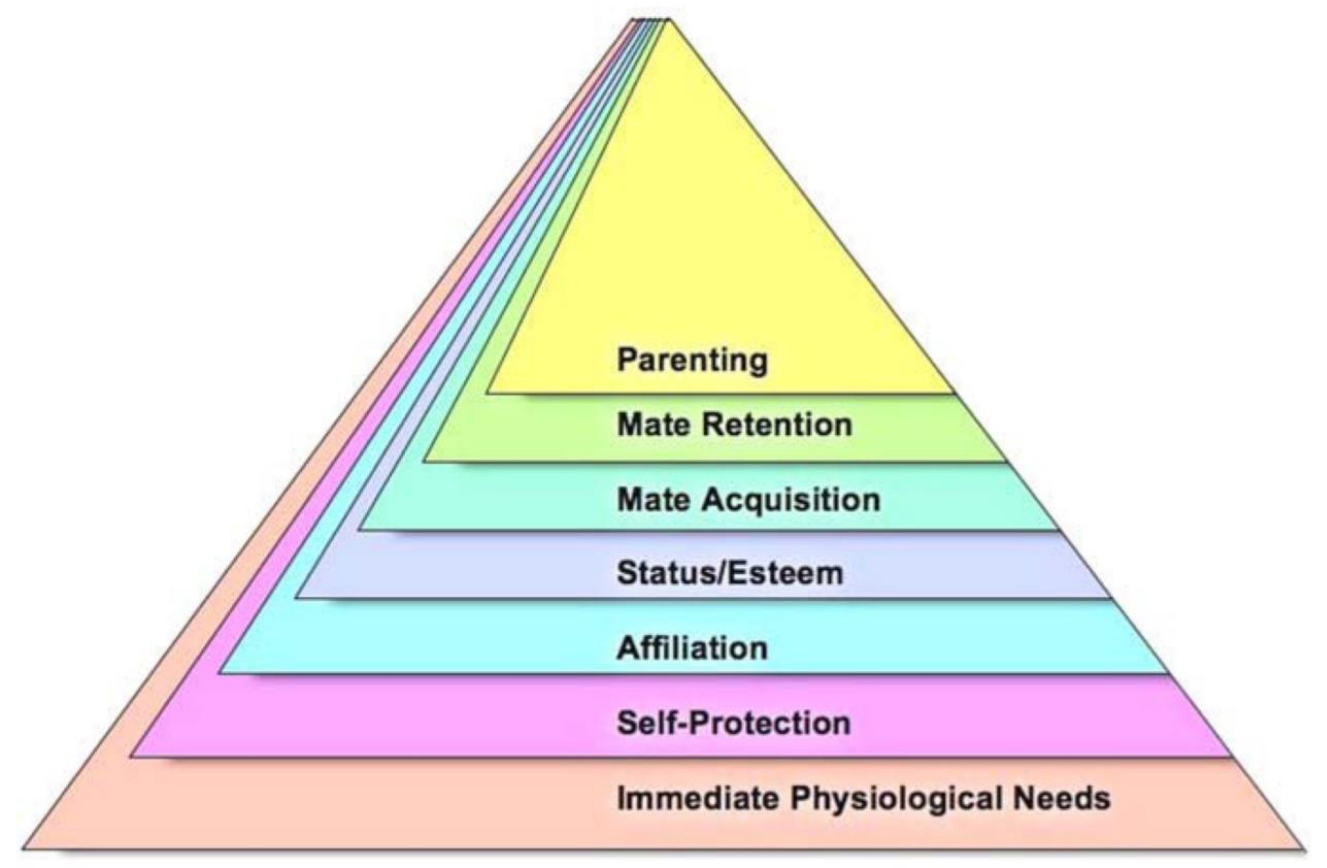

Figure 1. Updated Pyramid of fundamental human motives. Reprinted from Kenrick et. al (2010).

Immediate Physiological Needs

Immediate physiological needs involve search for things such as nutrients and liquids, aiming to satisfy internal physiological imbalances, reflecting metabolical individual differences and developmental exposure to different cues (Kenrick et al., 2010). Especially in non-industrialized societies, through PA, one can improve the way to forage during activities such as hunting and gathering, horticulturism and pastoralism.

\section{Self-Protection}

Self-protection involves search for safety, including avoidance from contagious diseases and unfamiliar persons/surroundings, is related with personality and physical size (Kenrick et al., 2010). PA can be directly connected to self-protection by running away from dangerous situations, or by avoidance, such as doing PA in well-illuminated areas.

Affiliation 
Affiliation dimension involves search for belongingness, and behaviors such as sharing, reciprocal altruism, having relations with pressure to follow social norms, cultural context, personality and vulnerability to disease (Kenrick et al., 2010).

Through evolution, group living had (and still has) a crucial importance for human beings, since it allows mutual protection and other activities directly related to survival (Cacioppo, 2011). In this sense, social motivation is very important, since having such a mechanism for monitoring moments of low social acceptance represented a survival value, since it allowed individuals to improve their reputation among the group (Kavanagh \& Scrutton, 2015). Frequently, PA are performed in groups because of socialization with others, strengthening bonds, and lowering social tensions.

\section{Esteem/status}

Esteem/status involves search for status enhancement, resources and mating, having relations with possible coalitions and mates, nature of previous and current interactions and self-efficacy (Kenrick et al., 2010). In PA, it can be manifested in motives such as competitiveness (e.g., to do a PA aiming to be the best, win at all costs, etc.), having in mind that success is a factor able to attract (mostly positive) attention of others.

\section{Mate acquisition}

Mate acquisition can be considered as a domain of sexuality that involves search for and flirting with desirable mates, thus being associated with mate value, age, sexual strategy, hormonal levels, available rivals, availability and distribution of resources (Kenrick et al., 2010).

From the evolutionary perspective, sexuality is one of the most important topics in organisms that reproduce sexually, and also is a complicated and complex phenomenon (Valentova \& Varella, 2016). In other words, it can be proposed as a primary impulse, in Bowlby's (1981) terms.

As argued by Lee-Manoel (2002), PA can involve, among other things, desire to interact with other people, including potential sexual partners, and can affect selfperceived and other-rated attractiveness. Thus, in PA, relations between mate acquisition and sexuality can be manifested in motives such as appearance (e.g., to do a PA aiming weight loss or increasing muscle size). An interesting research (Faurie, 
Pontier \& Raymond, 2004) found that student athletes reported having more sexual partners than non-athletes, with greater differences among men in comparison to women.

Mate retention

Mate retention represents a domain of sexuality that is related with expressions of love, intimacy, commitment, mate value, resources and alternative mates (Kenrick et al., 2010). PA can also be connected to competitiveness and status, and status maintenance can be a way to retain sexual partners.

Parenting

At the top of the motivational hierarchy, parenting involves investment in child care, being associated with paternity uncertainty, resources and number of children (Kenrick et al., 2010). PA can be associated to health-related motives, and a healthy person might be more able to provide care and resources.

\section{Sex Differences in motives for PA}

Sex differences or similarities impact processing of motivational relevant cues (Kenrick et al., 2010). However, studies approaching evolutionary-based sex differences in PA motivation are scarce. Among the rare examples, a great part strongly suggests that men's and women's motivation for PA would differ (Carvalho, 1998; Apostolou \& Lambrianou, 2017; Deaner et al., 2015). However, the studies were only applied to sports. Here, when possible, we try to extend this analysis to other types of physical activity.

Deaner et al. (2015) and Apostolou \& Lambrianou (2017) list several evolutionary hypotheses explaining sex differences in motivation for sports, as described in the next part.

\section{Allying with Coalitions}

This hypothesis is related to adaptations that allowed individuals to form and maintain coalitions with others in contexts of between-groups warfare (Deaner \& Winegard, 2010). Some of its characteristics includes a higher prevalence of male competitions, including warfare-relevant skills, associations in geographical areas, 
symbols of group identification and spoils after winning the contests (Deaner, Balish \& Lombardo, 2015).

Warfare is considered as a more male than female specialization, in which male-male competition is present to compete for resources monopolization, and also for women (Apostolou \& Lambrianou, 2017).

\section{Spectator Lek}

This hypothesis define sports as less dangerous (e.g. in comparison to war) physical competitions for status, mainly directed to men competing against other men. Indeed, women are not interested to the same extent in participating and monitoring sports as men (Deaner et al., 2015).

The Spectator Lek hypothesis also proposes a more competitive orientation/motivation in men for practicing sports.

This theory can be understood as complementing inter-sexual selection, since there are more men than women among sports fans.

Development of Skills

Some authors argue that practicing sports (and surely also other PA) can be done as preparation or training for future activities and contexts (Deaner et al., 2015, Apostolou \& Lambrianou, 2017), similarly to play behavior.

Development of skills can be a more balanced trigger to PA practice and motivation, because both sexes benefit similarly from some of PA correlates, such as higher self-discipline, perseverance in face of difficult situations, capacity of negotiating and following rules (Deaner et al., 2015).

\section{Courtship Display}

This hypothesis presents sports as a culturally invented signaling system with a function similar to courtship rituals of other animals (De Block \& Dewitte, 2009), where individuals that excel in performance generally have greater access to highly valued mates (Deaner et al., 2015).

Apostolou \& Lambrianou (2017) cite Trivers (1972) to hypothesize that women would be less prone to take part in athletic competitions, since throughout the lifespan they have more costs related to lactation and child care. 
Further, the courtship display hypothesis proposes that women would have more motivations linked to appearance, mainly when participating in more stylistic artistic activities (Deaner at al., 2015). This was proposed because these activities allow females to display mate and parenting relevant phenotypic condition, such as attractiveness, physical strength, and cardiovascular endurance.

\section{Socialization}

In consonance with courtship display, another strong reason to predict greater motives for appearance in women is attributed to cultural influences and socialization practices. In particular, opportunities given, parental and teachers/coaches incentives and encouragements, or society's level of patriarchy can contribute to higher involvement of men in competitive PA and higher appearance motivation in women to practice PA (Deaner et al., 2015).

\section{Important observations}

Despite the above outlined hypotheses, there is a lack of intercultural research, even among countries sharing partly their values and history. Cultural experiences are known to be associated with ecological factors (Kenrick et al., 2010). Thus, replication or analyses in other populations is very important. Despite sex differences are expected in domains in which men and women historically had to solve qualitatively different problems (Michalski \& Schackelford, 2010), according to specific scenarios and conditions, both sexes can face similar or more general problems, and there might thus be a reduced difference, or even no differences. Apostolou (2015) argues that, because of its related benefits, it is expected that individuals of both sexes would be motivated to practice PA.

In support to a more moderate view, the few Brazilian studies that compared men and women in their motivation for PA (Gonçalves \& Alchieri, 2010; Andrade Bastos et al., 2006) did not find sex differences as strong as predicted and showed by Deaner et al. (2015), or Apostolou and Lambrianou (2017). Sociability motives were greater in men (Andrade Bastos et al., 2006), and Fitness/Health motives in women (Gonçalves \& Alchieri, 2010). None of these Brazilian studies found sex differences in appearance motives for PA.

\section{Age Differences in motives for PA}


According to the renovated theory of pyramid of needs, priorities tend to change with developmental stage (Kenrick et al., 2010). For example, mating motives are supposed not to be manifested strongly until puberty.

In general, each developmental stage can affect the outcomes differently (Bateson, 1991). So, age is also expected to be related with different motives for doing PA. For example, participants with lower age have stronger appearance motives, which corresponds with their more prevalent desire to attract sexual partners.

To better discuss the above outlined topics, we will turn to explore physical activities and other related variables analyzed by the present study in more detail, to provide a greater understanding about the phenomenon.

\section{PHYSICAL ACTIVITY}

\section{Definitions}

One of the most important aspects of science is precision and terminological distinction, which contribute to a better scientific debate (Varella \& Valentova, 2019). So, it is valuable to discuss some definitions regarding PA, a field full of conceptual inconsistencies (Gonzalez \& Fensterseifer, 2014). Regarding motivational studies, the choice of term used, such as exercise, physical activity or sport, can influence the findings and its interpretations (Alltonen, Kujala \& Kaprio, 2014).

After definitions, in Chapter 2 we will present some of the PA classifications. Although we briefly discuss this topic in one of the articles, we will present the classifications here in more detail.

\section{Physical Activity}

Physical activity (PA) can be defined as a voluntary movement with energy costs superior to rest levels, aimed to attain some goal linked to Kinesiology dimensions (e.g., self-expression, leisure, health, and/or competition) (Hoffman \& Harris, 2013). Physical activities can be classified into specific sub-categories.

In epidemiological studies, it is common to see PA classified by domains, such as leisure, work, commuting, and household (e.g., Streb et al., 2019). However, the most common classification is made by splitting PA into sports and exercises. 
Sport

Sport is a specific PA related to the use of skilled movement in game contexts, with attributes such as competition, rules, institutionalization, standardization of equipment and venues, and striving for records (Hoffman \& Harris, 2013; Barbanti, 2003). Sports can be divided into individual, e.g., tennis, karate, gymnastics, and collective/team, such as football, rugby, basketball, volleyball (see Gilet \& Rosnet, 2008).

\section{Exercise}

Exercise, in turn, is a physical activity characterized as structured, planned repetitive movements aimed at enhancing or maintaining physical fitness/conditioning (Caspersen, Powell \& Christenson, 1985; Carvalho, 2006). As examples of exercises, we can cite bodybuilding, jogging, walking, stretching, functional training, etc.

Exercises can be subclassified according to different aspects of health-related physical fitness emphasized, such as flexibility, cardiorespiratory endurance, and muscular strength (Caspersen et al., 1985).

\section{Body/Movement Practice}

In addition to the two aforementioned internationally widely accepted classifications of physical activities into sports and exercises, there is another possible category called Body/Movement Practice that can be defined as a kind of activity based on gestuality, expression and care, in which the practice serves to self-care and also to care for others (Alves \& Carvalho, 2010; Carvalho, 2006).

The concept of Body Practice (in Brazilian Portuguese Prática Corporal) has been increasingly used by some Brazilian researchers (Lazarotti Filho, 2010). A term with similar meaning, Movement Practice, can be observed in articles from other countries (e.g., see Vergeer, 2018). To address both versions, as detailed in Chapter Two (Hsu \& Valentova, 2020), we opted to use the term Body/Movement Practice.

Following the definition of this category, and excluding activities that meet more clearly the definitions of sports (eminently competitive) or exercises (more repetitive), the following can be listed as examples of body/movement practices: Yoga, Pilates, Tai Chi Chuan, Liang Gong, dances and Gymnastics for All. 
However, the definition of Body/Movement practice is not as established as Sports and Exercises. In Brazil, the term has been used by researchers with several meanings, such as:

a) a critical alternative to physical activity. The term physical activity is considered by some authors as a term excessively associated with energy expenditure, which meets more the epidemiological standpoints (Carvalho, 2006; Carvalho \& Manoel, 2015);

b) a synonym of physical activity. As shown by Lazzarotti Filho et al., (2010), some Brazilian authors address both terms interchangeably. Some official organs also do not make distinctions between the terms (see, for example, the National Policy of Health Promotion: Brasil, 2010).

In the first chapter of the present study, we considered Body/Movement Practices as a specific category of physical activity, as illustrated in Figure 2. In this way, we were able to categorize activities in order to keep the traditional model (PA divided in sports and exercises), and still include some integrative and complementary activities (body/movement practices) which can differ from the traditional model (for additional details, see Chapter One).

Carvalho (2006) includes some sports into the construct of body/movement practices, but due to the highly competitive nature of some sport manifestations (e.g. in the Olympic games), we preferred to maintain body/movement practices and sports in different categories. Thus, we maintained the original meaning of body/movement practices proposed by Carvalho (2006) but included them within a broader model of physical activities as a specific category.

As illustrated in Figure 2, there can be some overlaps between the categories, because some activities can transit between two or more categories. Although all activities have some peculiarities, we also stress intersections between the categories, as shown by abcd on the figure. For example, a sport practiced more for social than competitive motives meets the body/movement practice definition and can be placed at (b) intersection. The same can happen with Pilates, a body practice structured in series of repetitive exercises, meeting (c) space. Halterophilism, for example, consists basically in exercises, however is performed under competitive, that is, sportive, settings, thus fitting the (a) zone. Finally, swimming, for example, can be practiced as a mere weight loss exercise, an individual sport or even a body/movement practice, 
depending upon the personal reasons involved. Thus, even an (d) activity can be considered, according to the context.

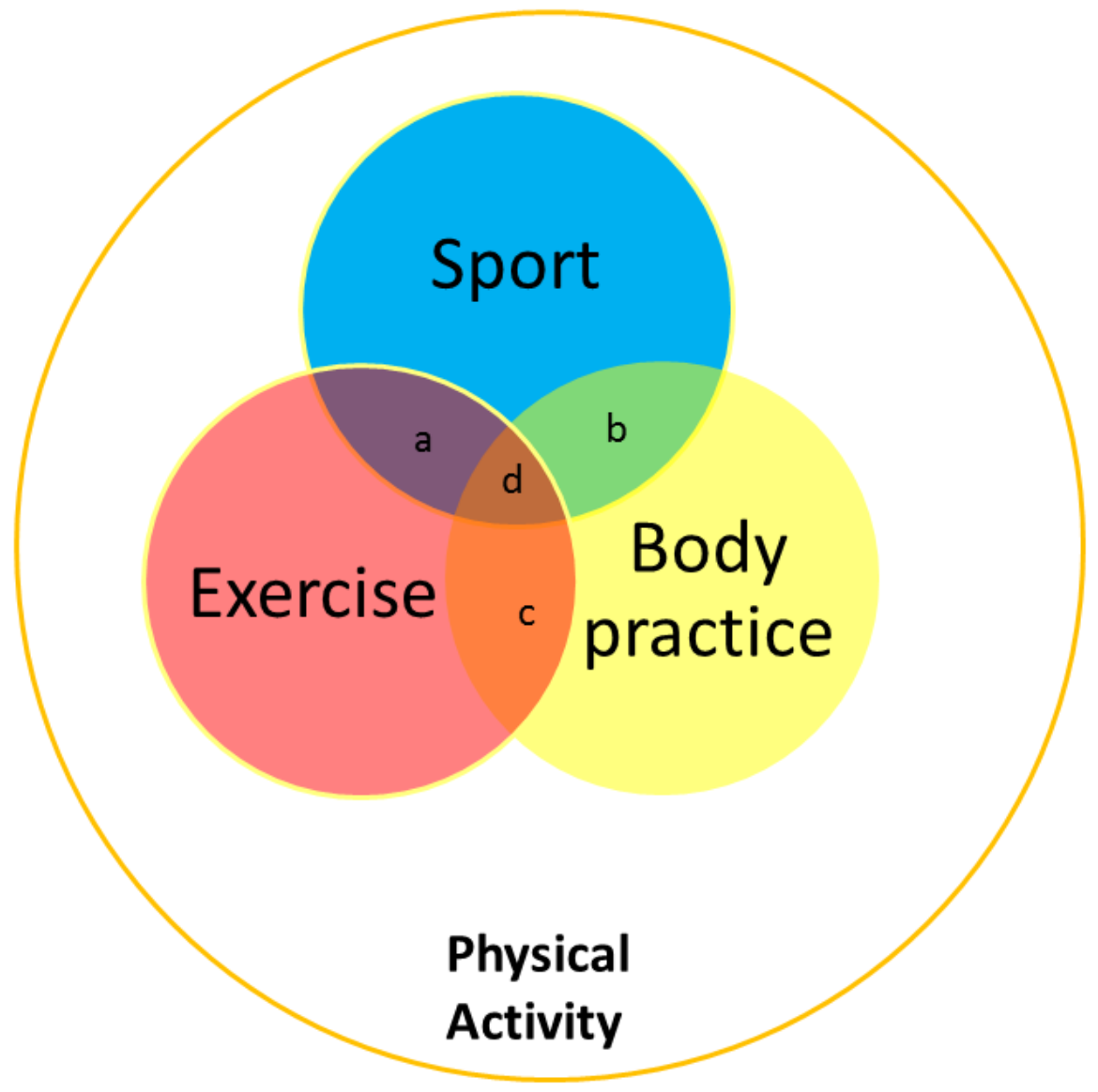

Figure 2. Categories of physical activities (Sport, Exercise, Body/Movement Practice) considered in this study. $a b c d=$ intersections between the categories suggesting possible overlaps.

However, it is necessary to test this new categorization empirically. We suggest that if we demonstrate a distinct pattern of motivations for body/movement practices, sports and exercises, we can support a relative independence of these categories of physical activities. As far as we know, no study has analysed motivations for body/movement practices as a specific category of physical activities. In reality, as shown by Carvalho and Manoel (2015), body/movement practices have been almost exclusively studied through the lens of social sciences, such as collective health. Thus, the first chapter of the present thesis intends to fulfill this gap, and test statistically potential differences in motivations with a classification of physical activities that 
includes body/movement practices as a distinct category separated from sports and exercises.

Since the majority of previous studies have not compared more categories than just sports and exercises, Frederick and Ryan (1993) suggested the importance of using a more detailed classification to improve the understanding of dynamics of the relationships among motivation and physical activity.

Increasing the knowledge is relevant because it can have important theoretical and practical applications. For example, important differences may exist among specific PA within one category, but are not detected, because of the global grouping criteria.

\section{Other classification systems of PA}

Several authors have proposed different possibilities of classification of PA, mainly regarding sports, such as individual/collective, with or without physical contact, with or without shared environment, more or less complex, with higher or lower organization, degree of cognitive overload, predominantly open or closed skills, domain of physical fitness emphasized, etc. (see Meira Jr. et al., 2020b; Barroso \& Darido, 2019; Gonzalez, 2004; Cardoso et al., 2020; Barbanti, 2003; De Rose Jr \& Silva, 2006).

Because of the great number of features such as intensity, purpose, setting, organization, and competitiveness, it is challenging to adopt a unique PA grouping and/or classification (Bélanger et al., 2015). A few authors have proposed classification systems able to compare more categories of PA simultaneously. In this sense, the epidemiology of PA frequently divides PA into leisure, household, transportation and work (e.g., Streb et al., 2019; Florindo et al., 2009). However, it has some limitations in application, since except for leisure time, all others tend to be practiced with less free will, i.e., they are more obligatory.

The language of physical education/sports sciences is considered very scattered (Gonzalez \& Fensterseifer, 2014). In addition, several of the existing classification systems lacks theoretical background supporting them. For example, the article of Molanorouzi et al. (2015), proposes a grouping of PA into Team Sport, Individual Racing plus Bowls, Racquet, Exercises, and Martial Arts. They do not provide, however, any theoretical reasoning for such division. The field still lacks broader classification systems, sensitive to psychological variables, such as 
motivation. Thus, broader classification systems would be welcome, possibly implementing them over time.

Cardoso et al. (2020) are among the few current authors focusing on datadriven criteria for proposing new classification systems of PA. The authors found that men preferred more complex PA and had a greater combativeness orientation (e.g., soccer), while women preferred more PA characterized by rhythmicity (e.g., dance).

Regarding motivation, it is known that some PA are inherently more intrinsically rewarding, such as games and some sports (Matias, 2019). However, to our knowledge, no previous study proposed PA classification according to motivation for PA practice.

\section{Positive and Negative Outcomes of PA}

Among others, behavioral change can include conscious evaluations about costs and benefits of the given behavior (Prochaska, 2008). Considering that motivational systems evolved to be sensitive to several variables, including evaluation of trade-offs in the ecological context (Kenrick et al., 2010), it is relevant to discuss possible positive and negative health consequences of physical activities. Further, we will outline issues related to insufficient or excessive levels of practice, having in mind also the evolutionary explanations. In addition, recommendations for PA are full of myths (Lieberman, 2020), and presenting empirically based evidence can be a way to reduce such issues.

There is a body of empirical evidence showing positive effects of regular physical activity on health, both physical and mental (e.g., Buckworth \& Dishman, 2002; Florindo, 2011; Lee-Manoel, 2002; Weinberg \& Gould, 2018). The contemporary global crisis of sedentarism is accompanied by several chronic diseases, such as hypertension, stroke, coronary artery disease, cancer, diabetes, osteoporosis and obesity, diseases negatively associated with physical activity practice (Florindo, 2011).

With respect to mental health, there is some evidence supported by epidemiological studies that PA contributes to reduction of several conditions such as suicidal ideation (Vancampfort et al., 2018), depression and anxiety (even under extreme circumstances, such as the COVID-19 pandemic: Meira Jr et al., 2020a), increasing, in contrast, self-esteem and well-being, being a relatively cheap nonpharmacological strategy (Buckworth \& Dishman, 2002). 
More than just improving health, physical activity practice is a way to give dignity to one's life (Matias, 2019). In this sense, health promotion strategies through physical activity, such as incentives for adoption of an active lifestyle, are well justified. However, depending on circumstances, not all PA are secure, because of potential physical risks, such as collateral effects on metabolism, blood or heart (Moran, 2004), or even psychological, such as exercise compulsions (Lane, 2008) including excessive drive for losing weight or increasing muscle size. This latter was associated with patriarchal and oppressive attitudes, and also social domination (Swami, Diwell \& McCreary, 2014).

In addition, it is necessary to be cautious about the manner to express the relation between PA and health, because of the risk to commit a symbolical violence, as discussed by Alves and Carvalho (2010) referring to frequently imperative style utilized in PA recommendations (both by media and PA professionals). Such style favors ideological approaches, in which sedentary people are viewed as lazy and as the only responsible for their condition- "victim's blame", a phenomenon also noted by other authors, such as Lieberman (2020) and Matias (2019). In addition to "victim's blame", there are two other common mistakes associated with promotion of PA: to view $\mathrm{PA}$ as a mere repetition of movements, and to emphasize static and rigid protocols of exercises (Matias, 2019).

Further, in order to better analyze PA and sedentarism, we can look at them through evolutionary lens by exploring the way in which insufficient levels of PA practice and sedentary behavior are related to health concerns and outcomes (see Farias Júnior, 2011).

The EHS concept of PA's functions for human survival in ancestral environments help to understand why situations of physical activity deprivation, such as sedentary behavior and insufficient levels of PA, are related to health problems (e.g., Cordain, Gotshall, Eaton \& III, 1998; Bortz, 1984). Cordain et al. (1998) cite phylogenetic evidence that, at least during the last 50 thousand years, the human DNA, on average, is almost the same, so the tremendous shift in human life since industrialization has not yet had time to change significantly our genetic profile. That means, as suggested by the authors, and also by Bortz (1984), that our current body was shaped by natural selection to be on frequent locomotor behavior, given that a great part of human ancestral environment required constant hunting and gathering activities. 
The troublesome situation of the current lifestyle can be associated with proximate causes. At ontogeny level, technological advances (e.g., locomotion with cars instead of walking) act as barriers to a full development of physical conditioning in comparison to some of our ancestors, who could be considered as true athletes regarding energy expenditure (Bortz, 1984).

In this sense, PA (especially moderate and vigorous) are in general scarcely present in everyday routines, showing up basically only in extraordinary and scheduled moments, not integrated with other daily activities (Cordain et al., 1998; Ryan, Frederick, Lopes, Rubio \& Sheldon, 1997). Thus, a great proportion of population does not benefit from the potential developmental plasticity acquired through evolution, such as the capacity to optimize through training, cardiac and lung functions, and bone mineral density (Bortz, 1984). Changing this scenario would not only improve people's lives, but also lower overall public and private health costs, since the optimizations of body systems is reflected in better health.

In this sense, the health benefits related to PA are not surprising. Because of this, the issue of low adherence and high sedentarism is normally considered as puzzling. Following the life history framework, Caldwell (2016) highlights the mismatch hypothesis, suggesting that PA in most ancestral environments was very often obligatory. Considering the associated costs, it would be adaptive to save energy stores at peaceful and abundant times and to allocate them later when necessary. From an evolutionary analysis of motivation, it also makes sense that an organism

opts for responses that cost less time and/or effort (Ades, 1985/2018). However, in a considerable part of modern Western industrialized societies, the peaceful and abundant times are nearly infinite, since thanks to the developed technologies, activities linked to food search and preparation were shrunk to a minimum. Thus, sedentarism tends to prevail.

\section{PERSONALITY}

According to Hollander (1967) and Martens (1975), as cited in Weinberg and Gould (2011), personality can be defined as a combination of characteristics that turn people unique. In this sense, personality psychology has concern with ways in which humans differ (Michalski \& Schackelford, 2010). Importantly, these definitions also apply to non-human animals, taking into account the increasing number of studies 
regarding personality in other species (e.g., Gosling, 2001; Gosling \& John, 1999; Franks, Higgins \& Champagne, 2014).

Personality is structured in the following dimensions (Weinberg \& Gould, 2011) (Figure 3):

a) Role related behavior- the most superficial and changeable part, which consists in the way the individual acts based on his/her perceptions about changes in environment. In other words, it proposes that people behave in different ways, as his/her perceptions of environment change;

b) Typical responses- situated on an intermediate level, are the ways each one encounter to fit the environment and the general responses to the demands;

c) Psychological core- the most stable and deep level, that includes elements such as values, attitudes, interests, motivations and self-concept.

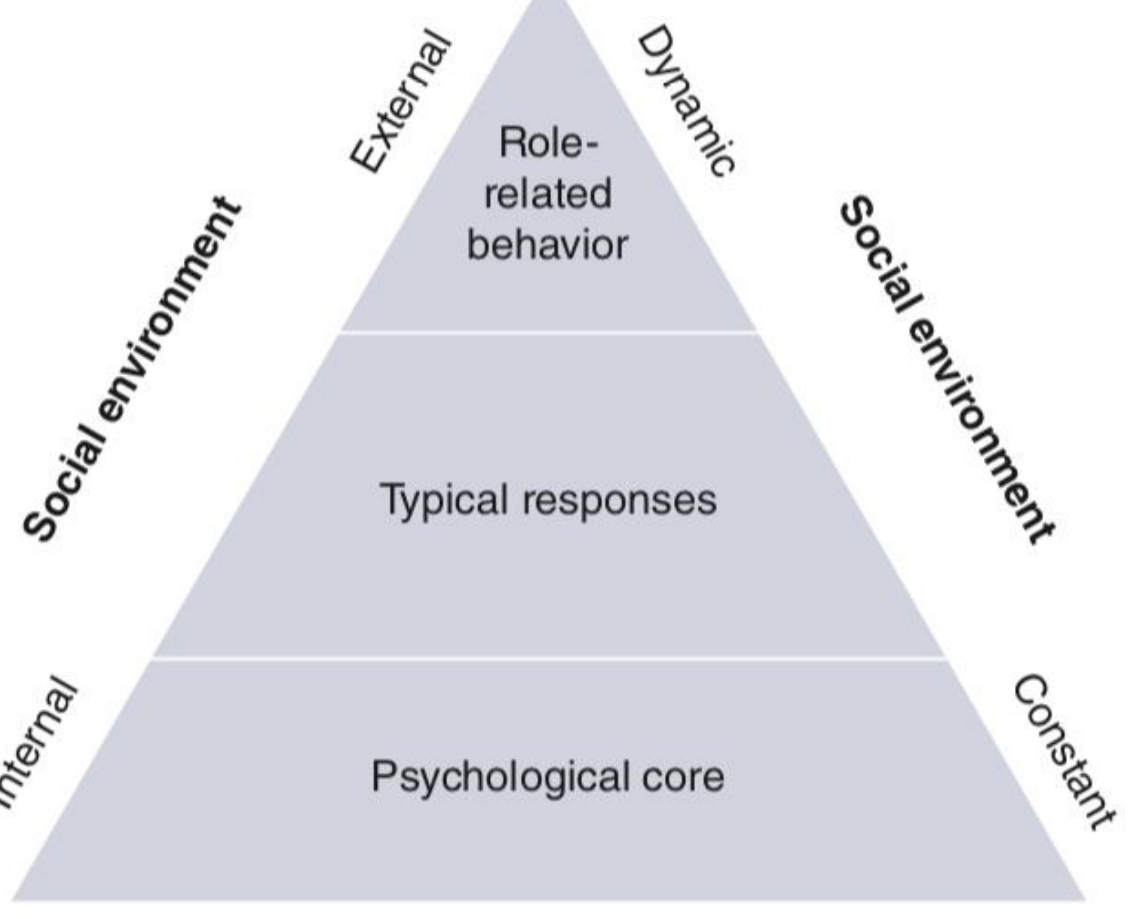

Figure 3. Structure of personality (reprinted from Weinberg \& Gould, 2011, which adapted from Martens, R. (1975) Social psychology and physical activity. New York: Harper \& Row).

Weinberg and Gould (2011) summarize a set of approaches that are pillars to the personality theories. This set is a continuum which centers around Psychodynamics, Trait concept, and Interactional and Phenomenological approaches. They are polarized between trait and situational extremes, and evolutionary approach 
possibly fits the middle of the continuum, together with interactionists perspectives (that are, according to the authors, the most accepted by the contemporary scholars of sport and exercise psychology), because these perspectives also include the person and environment as co-determinants of behavior.

Because describing all theories of personality would be beyond this work, we will focus on evolutionary approach to personality.

As with human nature in general, personality also is affected during ontogeny, and by structure and processes of natural and sexual selection (Michalski \& Schackelford, 2010). Within evolutionary psychological science, personality has been contemplated together with adaptive individual differences (Buss, 2009).

Individual differences are relatively stable and durable individual characteristics that are very relevant (Barbanti, 2003), also evolutionarily. Buss (2009) presents individual differences as highly evolutionary relevant, because they were essential to solve important adaptive problems, such as mate selection. Mate choice itself is mainly guided by differences, because it would be difficult, if not impossible, to choose a partner if all humans were physically and psychologically equal. Individual differences are also expressed in personality, intelligence and specific skills, mating strategies (such as sociosexuality), political beliefs and attitudes, religiosity, body type and mate value, among others (Buss, 2009).

Focusing on personality characteristics, Buss (2009) argues that these are to some extent heritable and stable, which is necessary for the evolution to be able to act upon. Personality thus has important evolutionary consequences. To understand personality and individual differences, Buss (2009) proposes that one way to comprehend personality is to think of individual differences as strategic differences presented in response to adaptive problems faced by humans (and also other social species), such as group hierarchy negotiations, alliance formation, resource extraction, conflict resolution and kinship.

\section{Five Factors Model of personality (Big Five)}

Among the different approaches used to investigate personality traits, here we will mention the widely used Five Factors Model (Big Five), which was also used in our study. Importantly, despite our preference for the Big Five, other models are increasingly adopted. See, for example, the six-factor model of personality- HEXACO (Lee \& Ashton, 2004). 
According to McCrae and John (1992), The Big Five model proposes that personality traits are hierarchically organized into five basic dimensions: Neuroticism/Emotional Stability- reflects tendency to experience affliction, preoccupation, anxiety and emotional instability; Extraversion- characterizes the individual in terms of sociability, being talkative, energetic and gregarious; Agreeableness- involves having compassion, sympathy, generosity and kindness; Conscientiousness- contemplates characteristics such as organization, caution, efficiency and productivity; and Openness to experience- structured in terms of curiosity, creativity and wider interests. Both high and low scoring in each of the personality traits has its positive and negative aspects. Thus, the personality does not show absolutely good or bad strategies, but rather an adaptive variation on possible matrix of personalities McCrae and John (1992).

Regarding an evolutionary approach to Big Five, some possible adaptive functions have been proposed (Michalski \& Schackelford, 2010): Extraversion in different levels could be an indicator of positions in hierarchies; Conscientiousness as a manifestation of whom to trust in important tasks; Agreeableness as an index of willingness to cooperate and conform to social norms; Openness as a criterion for seeking out advice; and levels of Neuroticism signalizing ability or not to negotiate tasks effectively.

However, the above cited adaptive functions are still to be subjected to further tests.

\section{Self-esteem}

Besides the Big Five personality model, in our study we also investigate Selfesteem, which refers to qualitative (positive and negative) judgements and feelings linked to descriptions everyone attributes to oneself, thus being the value attributed to self-concept (Lee-Manoel, 2002, Kavanagh \& Scrutton, 2015). These self-evaluations can be positive or negative (Kavanagh \& Scrutton, 2015).

One of the most important evolutionary views of self-esteem (Kavanagh \& Scrutton, 2015) is Sociometer theory (Leary \& Downs, 1995). Based on this theory, self-esteem of each individual works as an interpersonal monitor, reflecting how others view him/herself. Through evolution, group living had (and still has) a crucial importance for human beings, since it allows mutual protection and other activities directly related to survival (Cacioppo, 2011). In this sense, having such a mechanism 
for monitoring moments of low social acceptance represented a survival value, since it allowed individuals to make further adjustments seeking to improve their reputation within the group (Kavanagh \& Scrutton, 2015).

\section{Narcissism}

Narcissism is characterized by elevated sense of self and antagonistic interpersonal style (Gentile et al., 2013). Marshall, et al. (2015) observed that Facebook narcissists updated more frequently about their exercise routines, thus indirectly showing an association between PA and narcissism.

One evidence favoring such an assumption was reported by Yavari (2014), who found that bodybuilders showed a tendency for high levels of narcissism. The author considered such result as worrisome, since this trait can be related to potentially harmful behaviors in several aspects of life.

Because of reliability issues, Narcissism was excluded from statistical analyzes. However, we opted to maintain it in this general introduction, since it was part of our original project.

\section{Personality and PA}

Research on PA and personality show associations between Big Five and PA. In relation to preference for $\mathrm{PA}$ in general, it was shown that, when comparing different types of PA, extroverted individuals tend to prevail among collective sports and introverts among individual sports (Weinberg \& Gould, 2011). However, the authors showed no evidence showing a difference in personality profile between athletes and non-athletes (Weinberg \& Gould, 2011). That is, personality is not necessarily associated with having success in PA.

Two meta-analyses (Rhodes \& Smith, 2006; Wilson \& Dishman, 2015) showed that doing PA is negatively associated with neuroticism and positively with conscientiousness and extraversion.

Further, self-esteem is positively related to PA (Weinberg \& Gould, 2011). However, most studies on this topic are cross-sectional, and thus it is not clear whether PA are molding self-esteem positively, or whether self-esteem predisposes people to be more physically active (see Lee-Manoel, 2002). In this sense, more longitudinal studies are needed. 
One study regarding personality that inspired this thesis was done by Marshall, Lefringhausen e Ferenczi (2015), who observed associations between Big Five, Selfesteem, Narcissism, and topics published on Facebook. Also, they studied if the associations were anticipated by different motives related to use of the social network. In other words, Marshall, et al. (2015) tried to comprehend the different motives for people using Facebook, and the relation of this with personality differences. Their main results were:

-extraversion was associated with more updates about social activities and routine, and intentions to communicate;

-neuroticism was related with Facebook use for social validation;

-openness correlated with updates about intellectual topics, and use of information and self-expression;

-conscientiousness was related with writing more about own children and use to share information and communicate (being possibly an indirect form of competitive parenting);

-self-esteem was inversely correlated with updates about current romantic partner (being possibly a way of people with low self-esteem to cope with worries regarding their relationship);

-narcissism, in addition to updates about exercise routines was also associated with use for validation and updating about achievements.

Studies such as these are important, having in mind the great adherence (at a global level) of population to this social network site. We were inspired by this study and we hypothesized that we might apply a similar approach to study physical activities. Although PA and Social network are distinct phenomena, e.g., on energy expenditure, we evaluate such an extrapolation as possible, mainly because both share some important aspects, such as self-presentation. Because of this, in one of our chapters we aimed to study specifically relations between motivation, personality and participation in PA.

Two relevant scientific dichotomies are pointed by Weinberg and Gould (2011) in relation to the link between personality and physical activity: the Nature vs Nurture and the Gravitation vs Change.

Nature-Nurture is grounded on a perspective in which personality has a genetic component and other environmental, in shared proportions, considering as false both extreme perspectives. Bussab and Ribeiro (1998) points out that to understand 
profoundly the inter-relation of nature with nurture is a key-factor to comprehend humanity.

As presented by Lee-Manoel (2002) for self-esteem, the Gravitation vs Change dichotomy contemplates the debate between the hypothesis that individuals are attracted to specific PA because of their personality profile (Gravitation) or because participation in PA promotes changes in personality (Change). Weinberg and Gould (2011) suggest that neither perspective can be fully rejected, since both of them have some truth. Again, the inter-relation of gravitation with change should be contemplated by more research.

Next, we will briefly introduce sexuality that, as shown by Schmitt (2008), is closely associated with personality. Besides that, we intend to show that sexuality can be potentially related with practice of $P A$.

\section{SEXUALITY AND SOCIOSEXUALITY}

From the evolutionary perspective, sexuality is one of the most important topics in organisms that reproduce sexually. In other words, it can be considered as a primary impulse, in Bowlby's (1981) terms. The Renovated Pyramid of Needs includes aspects of sexuality in great detail, see above (Kenrick et al., 2010).

Sexuality is a complicated and complex phenomenon (as pointed by Valentova \& Varella, 2016), and to discuss the whole complexity would be beyond the scope of this work. Thus, here we only pinpoint a specific narrow concept of sociosexuality which received considerable attention in evolutionary literature.

As presented by Penke e Asendorpf (2008), the term sociosexuality was introduced by Kinsey to describe individual differences in propensity to engage in noncommitted sexual relations with a variety of sexual partners. In 1991, Simpson and Gangstead developed the Sociosexual Orientation Inventory (SOI), in which individuals are classified as more unrestricted- with a more tendency to promiscuityor restricted- having a more monogamous orientation, with prolonged relationships and a high emotional investment (Penke \& Asendorpf, 2008; Schmitt, 2005).

$\mathrm{SOI}$, in other words, is one of the measures of self-rated individual differences in mating strategies (Schmitt, 2005). This instrument was adapted by Penke and Asendorpf (2008), who constructed the global sociosexual orientation as composed of different psychological components, each one uniquely contributing to sociosexuality 
with only a partial overlap. The sociosexuality dimensions are Behavior, Attitude and Desire:

a) Sociosexual Behavior- refers to investments in short- or long-term relationships. Previous studies revealed that SOI behavior influences the quantity of past and current relationships, sexual infidelities and self-perception of mate value (Penke \& Asendorpf, 2008). Individuals scoring higher in this domain (i.e., had a history with more uncommitted relationships) also show a higher tendency to present multiple sexual partners later in life, and unstable relationships;

b) Sociosexual Attitude- entails reflections about desire for emotional proximity before sexual intercourse, and is related to moral feelings. The study by Penke and Asendorpf (2008) showed that this was the only component negatively associated with flirting behavior. Besides that, attitude was more restricted when partners flirted with alternative mates or when committed to religious values;

c) Sociosexual Desire- is characterized as a motivational state of heightened sexual interest, frequently accompanied by fantasies and excitement, being directed also to people without romantic commitment. The authors suggest that this can be the main factor responsible for global differences in sociosexuality between the sexes (Penke \& Asendorpf, 2008).

As emphasized by Penke and Asendorpf (2008), it is possible to conclude that an individual level of sociosexuality cannot be understood as something merely constant (trait), because it develops during the interaction between the individuals' behavior and environment. One example cited by the authors is that an individual more prone to unrestricted sociosexuality can change to a more restricted attitude, or vice versa, in order to have higher future mating success. This change is influenced by upbringing influences or previous experiences, such as frustrating relationships with a restricted partner.

As argued by Lee-Manoel (2002), PA can involve, among other things, desire to interact with other people and self-perceived attractiveness. Thus, there might be a clear relationship between PA and sexuality. However, despite the relevance of association between sexuality and PA, research on this relationship is very scarce. For example, Teixeira et. al. (2015) showed that between 2010-12, only 3 papers linked to sexuality were published by physical education research teams, among all 
343 research teams registered in Brazilian National Council for Scientific and Technological Development (Conselho Nacional de Desenvolvimento Científico e Tecnológico- CNPq). The present work is thus very relevant.

In the international context, Swami et al. (2014) found that, in a sample of British men, unrestricted sociosexuality was one of the factors that anticipated greater drive for muscularity. Unrestricted sociosexuality was also positively and significantly correlated with sexual sensation seeking, sexual esteem and sexual assertiveness. Another interesting research found that student athletes reported having more sexual partners than non-athletes, with differences greater among men in comparison to women (Faurie, Pontier \& Raymond, 2004).

On the other hand, there is an extensive cross-cultural research on relation between sociosexuality and personality. One of the biggest studies conducted by Schmitt and Shakelford (2008) in more than 46 nations, showed that unrestricted sociosexuality was significantly and positively correlated with extraversion, and negatively with agreeableness and conscientiousness. Further, Neuroticism was also negatively and openness to experience positively related to promiscuity, although both associations were relatively weak.

\section{ADDITIONAL JUSTIFICATIONS TO STUDY MOTIVATION FOR PA AND ASSOCIATED FACTORS}

With our research we aim to fill important gaps in the literature:

1) This is the first study to surpass the exercise-sport dichotomy by adding body/movement practices as a category;

2) Research attempting to link motivation for PA through an evolutionary approach is scarce, especially using a less WEIRD ${ }^{3}$ sample outside the USA/Europe;

3) Much is known about PA's benefits to health, however, far less is being studied about mechanisms and reasons/motivations that help explain why individuals keep practicing or not behaviors they know are beneficial to their health (Batia, 2007);

4) The current study adopts a comprehensive focus, because studies on motivation for PA applied to a diverse broader public are lacking (Weinberg \& Gould, 2018). As will be discussed in more detail in Materials and Methods, our pool of participants was not restricted to a specific PA group such as tennis players, runners

\footnotetext{
${ }^{3}$ Western, Educated, Industrialized, Rich, Democratic.
} 
or dancers, but rather to a more general public. Besides that, only a few researches attempted to compare motivation for practice of different PA in the same study (Frederick \& Ryan, 1993);

5) The study has important potential applications. According to Batia (2007), to better understand the relationship between motives and personality is fundamental to increase action and maintenance in programs focused on health promotion through PA practice. Comprehending the motives why people engage or not on PA, as well as the associated factors, PA classes can be further adjusted to meet every patient/student/client need, and also to reduce possible barriers to participation. 


\section{AIMS AND HYPOTHESES/PREDICTIONS}

AIMS

Our general goal was to investigate individual differences in motives for practice of different PA (e.g., individual and collective sports, exercises and body/movement practices), and also some other variables, in a Brazilian sample. Our specific aims are described with more detail in each chapter. In brief, we aimed to:

a) investigate the influence of physical activity type, sex and age on motivations (intrinsic and extrinsic) for practice of different PA.

b) analyse PA with or without previous groupings, to explore which ones would be more similar according to different motivational subscales.

c) verify relations of different groups of physically active or sedentary participants with personality scores (Big Five, self-esteem), and sociosexuality (DRAFT)

\section{HYPOTHESES/PREDICTIONS}

Regarding our predictions, they were elaborated taking into account the previous reports on literature, mainly: Frederick and Ryan (1993); Ryan et al. (1997); Rhodes and Smith (2006) Batia (2007); Gonçalves and Alchieri, 2010; Apostolou (2015); Deaner, Balish and Lombardo (2015); Marshall et al. (2015); Wilson and Dishman (2015); Apostolou and Lambrianou (2017). They can be grouped as follows:

a) H1: Different types of PA would be associated with different motives. Prediction 1: In relation to the type of $\mathrm{PA}$, we expected that sport practitioners would score higher on competence, social and interest/enjoyment subscales; exercise practitioners would score higher on appearance and health subscales; and body/movement practices practitioners would score higher than exercise ones on competence and enjoyment subscales.

H2: Sex would be differently associated with different motives. Prediction 2: We expected that women would score higher on appearance and fitness/health subscales, whilst men would score higher on social subscale; Prediction 3: men and women will not show differences in any motivations 
H3: Different age groups would be associated with different motives. Prediction 4: We expected younger participants scoring higher on interest/enjoyment and appearance, while fitness/health motives would increase with age.

H4: Different classifications of PA would converge consistently with different motives. Prediction 5: PA similar in complexity and structure will show similar motivational profiles (e.g., soccer and football). Prediction 6: Traditional PA classification systems (e.g., sports and exercises) will not be fully reflected in motivation, thus emerging different groupings according to each analysed motivational subscale.

H5: Personality and Sociosexuality would differ according to PA participation. Prediction 7: Regular participants of physical activities (PA) will differ from sedentary ones in personality (Big Five and self-esteem), sociosexuality and self-reported attractiveness and health. We predicted that physically active participants would score higher on extraversion, conscientiousness, openness, self-esteem, rated attractiveness and health, sociosexual behavior and lower on neuroticism than sedentary participants. Prediction 8: Differences in personality (Big Five and self-esteem), sociosexuality and self-reported attractiveness and health will also be shown when comparing physically active participants doing PA for more than 6 months (maintenance) and those practicing for less than 6 months (action). We expected the Action group showing intermediate scores in comparison to Maintenance and Sedentary. 


\section{MATERIALS AND METHODS}

This chapter presents generally the procedure employed in the four subsequent chapters/articles. See more details in the chapters.

\section{RESEARCH DESCRIPTION}

According with Thomas, Nelson and Silverman (2012) criteria, the present research can be defined as a survey, with a descriptive and cross-sectional outline. As an evolutionary oriented research, it is also important to add that it has a more proximate emphasis, focusing on partly conscious and self-reported aspects.

\section{SAMPLING PROCEDURES}

Sampling, was done by convenience, specifically by using snowball technique, which is described as a technique in which key people are contacted to disseminate the research to potential participants (Coolican, 2014). In our case, the snowball was done mainly by recruitment solicitations to mailing lists of students (mainly undergraduate) and employees (mainly professors) from University of São Paulo, and also to general public, and through social networks, such as Facebook and WhatsApp.

The only requirement to participate was to be over 18 years old. That is, any person interested to participate could do so, even if sedentary. Also, before any data collection, the project was approved by the Ethical Review Board of the Institute of Psychology of the University of São Paulo (number 1.506.8994).

The main characteristics of the sample can be found in section "DESCRIPTIVE CHARACTERISTICS OF PARTICIPANTS"

\section{INSTRUMENTS}

We collected data through electronic anonymous questionnaires. Before response initiation, the participant was directed to the Informed Consent Term (APPENDIX 1). It included some general information about the research and its aims,

\footnotetext{
${ }^{4}$ Available at: $<$ https://drive.google.com/file/d/OB4gW8k4QcLaLR0VXM1VLRGczRGs/view?usp=sharing\&resourceke $\mathrm{y}=0$-vqhbXpjgxUPkb81Z932lcg>
} 
justifications, possible risks, approximate time needed to fill the questionnaires and filling instructions. The participants were informed that they could leave in any moment, and, in this case, all data collected would be discarded. Besides that, participants were informed they could contact the responsible researchers if they were interested in receiving more information (or a detailed report containing the main results of the study).

We share the opinion with several authors of the book organized by Guerreiro, Schmidt e Zicker (2008) that giving a feedback about the research to participants is an ethic and social responsibility which the researchers should not avoid. We shared links of the project created on ResearchGate, containing several materials published since 2016.

All questionnaires were presented in Brazilian Portuguese, almost in the same way as presented on Appendices. No payment was provided for participation. The questionnaires were applied in the following order:

\section{Sociodemographic questionnaire}

Sociodemographic questions were employed for the purpose of obtaining general information to permit characterizing the sample. It included short questions of multiple choice about sex, age, height, body mass, sexual orientation, religion, race/color/ethnicity, self-evaluation of attractiveness and health, socioeconomic status and scholarship.

\section{Practice of PA}

At the end of the sociodemographic questionnaire page, we asked an open question, in which the individual reported the physical activity most practiced regularly, and for how much time they practiced it. In the first article, these data were used to categorize the participants into 4 groups of PA- Collective Sports (CS), Individual Sports (IS), Exercises (EX) and Body/Movement Practices (BP).

\section{Short Questionnaire to Assess Health-enhancing Physical Activity}

The questionnaire (APPENDIX 3) has 11 items related to weekly frequency, approximate duration (per day) and effort perception of each physical activity practiced on different domains, being 2 for displacement activities, 5 for leisure time activities 
(on item "Sports", the individual could inform until 4 activities practiced), 2 for domestic activities and 2 for labor activities.

One advantage of using this questionnaire is that it can be responded by any participant (sedentary or physically active), since it contemplates activities from several domains, not only leisure time (e.g.: walking from home to work). We made a little adjustment on the instrument replacing the term "Sports" for "Sports/Exercises/Body Practices", see below.

\section{Motivation for physical activity measure revised}

The Ryan et al. (1997) Motivation for Physical Activities Measure Revised (APPENDIX 5) consists of a new version of the original scale formulated by Frederick and Ryan (1993). It measures, in 30 items, five factors related to motivation for participation in PA: interest/enjoyment motives, competence motives, fitness/health motives, appearance motives, and social motives. Motives of interest/enjoyment and competence reflect aspects of intrinsic motivation, while appearance, fitness/health and social reflect aspects of extrinsic motivation.

The scale showed a good consistency, as the authors' Cronbach's alphas for the subscales ranged from 0.78-0.92 in the original study.

In our study, the Cronbach's' alphas were very similar to the original study, as shown below (Table 1):

Table 1- Internal consistency scores of the MPAM-R (Motivation for physical activity measurerevised) in our research and original validation.

$$
\text { Ryan et al. (1997) Our study }
$$

\begin{tabular}{lcc}
\hline Interest/Enjoyment & .92 & .92 \\
Competence & .91 & .90 \\
Social & .83 & .85 \\
Fitness/Health & .78 & .80 \\
Appearance & .88 & .89 \\
\hline
\end{tabular}




\section{Sociosexual Orientation Inventory Revised}

SOI-r (APPENDIX 6) refers to an adaptation (Penke \& Asendorpf, 2008) of the original Sociosexual Orientation Inventory (SOI-r) (Simpson \& Gangstead, 1991), and was developed as an alternative view to the original scale's global focus. This new inventory seeks to evaluate sociosexuality based on 9 items referred to specific dimensions of behavior, desire and attitude.

\section{Rosenberg's Self-Esteem Scale}

This Brazilian Rosenberg's Self-Esteem Scale (APPENDIX 7) is based on a previous adaptation by Hutz (2000). The scale has 10 items, separated into 6 questions referring to positive self-evaluation, and 4 referring to negative selfevaluation.

The reference scale (Sbicigo, Bandeira \& Dell'Aglio, 2010) has good reliability, as Cronbach's Alphas ranged from .70 to .77 . Our study showed higher internal consistency of the self-esteem inventory, as shown below.

Tabela 2- Internal consistency scores of the self-esteem scale.

\begin{tabular}{lcc}
\hline & Our study & $\begin{array}{c}\text { Sbicigo et al. } \\
(2010)\end{array}$ \\
\hline Positive items & .83 & .76 \\
Negative items & .84 & .77 \\
Total Score & .89 & .70 \\
\hline
\end{tabular}

\section{Reduced Scale of Personality Descriptors (RED5)}

This scale (APPENDIX 8), created by Natividade and Hutz (2015), is aimed to analyse the Big Five personality dimensions: Extraversion, Neuroticism, Conscientiousness, Agreeableness and Openness in a faster, but still reliable way. The scale has 20 items, 4 for each facet, and Chronbach's Alphas ranging from .52 to 81 .

In general, the Cronbach's Alphas from our data were similar (also greater, in almost all factors) than in the validation reported by Natividade and Hutz (2015). 
Similar to them, only extraversion and agreeableness had satisfactory scores, which emphasizes the limitation of this instrument regarding its number of items per factor.

Table 3- Internal consistency of the RED 5 questionnaire (Reduced version of Big Five) in our research and the original validation.

Our study Natividade \& Hutz (2015)

\begin{tabular}{lll}
\hline Extraversion & .86 & .81 \\
Neuroticism & .68 & .66 \\
Openness & .50 & .52 \\
Conscientiousness & .68 & .67 \\
Agreeableness & .82 & .80 \\
\hline
\end{tabular}

\section{STATISTICAL ANALYSES}

Initially, a basic treatment of the data was conducted, followed by descriptive statistical analyzes to characterize the sample, and also to eliminate extreme outliers. For the statistical analyzes, the software Statistical Package for Social Sciences (SPSS), version 21, was used. In each chapter, the specific analyses are described in the respective Materials and Methods section. Before the specific chapters, we present a section that generally presents descriptive analyses and also some basic inferential statistics.

Briefly, in Chapter One, the first author of the article (Rafael M. C. S. Hsu) categorized participants into one of the following four groups, according to type of PA most practiced: Individual Sport, Collective Sport, Exercise or Body/Movement Practice. To test type of PA, sex and age effects on motivation, Multivariate General Linear Models were performed, using motivation type (social, fitness/health, interest/enjoyment, competence, appearance) as dependent variable, while type of PA and sex as independent variables, and age as a covariate.

Chapter Two had two parts: one similar to Chapter One, but analyzing several other classification systems proposed by other authors, and a second part, more datadriven, without major groupings of PA. In the first part, PA were classified by Rafael M. C. S. Hsu and Fernando L. Cardoso according to: Complexity-Organization (Naylor 
\& Briggs, 1963); Number of Participants- Individual, Team or Both; Physiological Demand- Strength, Cardiorespiratory or Hybrid (Caspersen, Powell \& Christensen, 1985); Intensity of Energy Expenditure- Light, Moderate or Vigorous (Ainsworth et al., 2011); and Motor Orientation- Combativeness, Rhythmicity or Water Practices (Cardoso et al., 2020). Separated Multivariate General Linear Models were performed, using motivation type (social, fitness/health, interest/enjoyment, competence, appearance) as dependent variable, and each category of PA as the fixed factor. In the second part, we compared the 33 (most practiced of our dataset) PA among themselves without major groupings, also regarding each type of motivation for doing PA (social, fitness/health, interest/enjoyment, competence, appearance). We performed Kruskal-Wallis analyses of variances with PA as fixed factor, and each motivational subscale as dependent variable.

In Chapter Three, taking into account the Transtheoretical Model of Behavior Change proposed by Prochaska and DiClemente (1983), participants were grouped according to temporal involvement in PA, and sedentary participants (reported doing no PA regularly) were compared with active participants doing PA for more than 6 months (maintenance) and those practicing for less than 6 months (action). We performed Multivariate General Linear Model (GLM) with Big Five, self-esteem, sociossexuality and other self-evaluations as dependent variables, while group of participants (Sedentary, Action or Maintenance) as fixed factor, and age as a covariate.

Additional specific/complementary analyses are detailed in the respective chapters.

\section{SOCIODEMOGRAPHIC CHARACTERISTICS OF PARTICIPANTS}

Here we describe some general sample characteristics.

The final sample was composed by 3719 responses, from which were excluded:

-18 , because they did not agree with the Consent Term (for these people, no questionnaire was applied;

-15 , because they declared age lower than 18 ; 
-1034, because they did not finish all questionnaires (interrupted participation without return or left too many items in blank). Importantly, not necessarily all 1034 participants really dropped out from the research. It may be that some participants interrupted participation at a given moment, returning to answer on another device, which makes count as a new response. For example, if a participant starts to answer through smartphone, but later decides to finish through a computer, the Qualtrics software does not let continue from the point of the previous device, because it only saves the data for further resuming on the same device in which the answer was started. So, in this example, the participant had to restart the survey, with the last uncompleted response considered as a dropout.

Thus, 2652 participants (mean age $=25.86, S D=9.81$ ) composed the final dataset, which was used for descriptive and inferential statistics. Of these, $1420-54 \%$ (mean age $=26,83$, DP $=10,49$ ) declared themselves as regularly physically active.

It is worth to note that, among the participants not excluded from the study, some of them had not answered all items, and some answers left in blank were accepted, considering a possible distraction or an unwillingness to answer a specific question. We believe that using a forced choice format could potentially create more dropouts, since people could not skip any discomforting question. For example, we noted several participants skipped SOI but finished the participation filling the Big Five (the last questionnaire), possibly feeling discomfort with these very intimate questions regarding sexuality. Also, according to Costa $(2021)^{5}$, forced choice would also show an important methodological difference, because it would emphasize decision making, which is not our aim.

Variable's treatment:

-Sex: 7 participants did not select "male" or "female", but have selected the option "other". Of these, 6 confused sex with gender (ex. Responded they were gender non-binary), while 1 declared transsexuality;

-Personality, sociosexuality and motivation scales: all participants who have not answered an item were considered as missing in the respective subscale. In these cases, the entire questionnaire was not considered when a total score was computed. But when other subscales were completed and the questionnaire does not have a total

\footnotetext{
${ }^{5}$ Doctoral dissertation argument, 2021, november, 29.
} 
score (e.g., Big Five and motivation), the completed subscales were considered for further analyses;

In the following section, we describe basic treatments given to some of the main dataset variables, and also some basic descriptive statistics.

\section{AGE RANGE}

Following Apostolou (2015), variables categorizing participants in different age categories were created (18-30, 31-50 and over 50 years), aiming to allow addressing of possible age cohorts' effects. However, due to the great concentration of participants in the first category, an additional division was also made to show a more balanced categorization (Table 4).

This categorization was not included in Chapter One, but remained here because of its descriptive power, and because it can be useful in analyzes of future articles.

Table 4- Age in 4 categories

\begin{tabular}{lrr}
\hline & Frequency & Valid \% \\
\hline $18-23$ & 1584 & 60,0 \\
$24-30$ & 591 & 22,4 \\
$31-50$ & 332 & 12,6 \\
$>50$ & 132 & 5,0 \\
& & \\
Total & 2639 & 100,0 \\
\hline
\end{tabular}

\section{RELIGION}

Our religions' options were based on Brazilian's most popular religions, according to Brazilian Institute of Geography and Statistics (Instituto Brasileiro de Geografia e Estatística- IBGE, 2010): Catholic, Evangelical/Protestant, Spiritist, none and other (e.g., Umbanda, Candomble, Buddhism, believe in God but don't have religion, does have two or more religions, etc.). In our sample, predominantly specific of university population, the pattern was very contrasting with the Brazilian population. For example, in IBGE (2010) data, 7.9\% declared to not have a religion, while in our sample $41.3 \%$ declared to not have a religion. 
Besides that, given that in our sample a great proportion of participants did not categorize themselves into the main categories (i.e., they answered the "other" option), in further analyses we will divide them into other categories, such as eclectic/undecided (people that believe in two or more religions).

Table 5- Religions in Brazil, according to Brazilian Institute of Geography and Statistics (IBGE, 20106) are listed on the left side, on the right side are the same religions represented in our sample.

\begin{tabular}{lcc}
\hline \multicolumn{1}{c}{ IBGE 2010* $(\%)$} & Our study $^{\$}(\%)$ \\
\hline Catholic & 65,1 & 28,19 \\
Evangelical/ & 21,6 & 8,56 \\
Protestant & 2,2 & 12,39 \\
Spiritist & 3,1 & 9,59 \\
Other & 7,9 & 41,27 \\
None & & \\
& 100,0 & 100,0
\end{tabular}

${ }^{*}$ Absolute numbers (million): Catholic (105.4), Evangelical/Protestant (35), Spiritist (3.5), Other (4.9), None (12.8). ${ }^{\$}$ Absolute numbers: Catholic (744), Evangelical/Protestant (226), Spiritist (327), Other (253), None (1089)

\section{RACE/COLOR/ETHNICITY}

Here we also followed the IBGE, and, as with religion, some (32) participants answered with the option "other", which instigated reflections, such as the necessity of future research having more consideration with peculiarities related to Brazilian's sample heterogeneity.

One way to do this could be to give another option among the primary, such as "mixed race".". In addition to this, the recommendation to further research include an intermediate option, which may help to best describe the sample.

Several people may have selected one of the offered options, such as "white" because they did not have a more precise option. This may cause some stress with the lack of possibility of inclusion, because participants may have (and value) a strong ancestry in other ethnicities, that could be revealed by a different way of asking.

Table 6- Main race/color/ ethnicities from the present study. 


\begin{tabular}{lrr}
\hline & Frequency & Valid \% \\
\hline Black & 98 & 3,7 \\
Oriental & 171 & 6,5 \\
White & 1999 & 75,5 \\
Brown & 340 & 12,8 \\
Indigenous & 7 & 0,3 \\
Other & 32 & 1,2 \\
Total & 2647 & 100,0 \\
& & \\
\hline${ }^{*}$ pardo (Brazilian). & &
\end{tabular}

\section{EDUCATION}

As illustrated below, in our sample a great proportion of participants were undergraduate students, followed by those who finished high school (ensino médio) and graduation (ensino superior), and also graduated (mainly Ph.D. students and Professors). However, the sample was under-represented by participants with incomplete high school, which is a great proportion of Brazilian population (IBGE, 2010).

Table 7 - Education

\begin{tabular}{lrr}
\hline & Frequency & Valid \% \\
\hline Elementary School- Incomplete & 3 & 0,1 \\
Elementary School- Complete & 5 & 0,2 \\
High School- Incomplete & 2 & 0,1 \\
High School- Complete & 142 & 5,4 \\
Undergrad- Incomplete & 1790 & 68,1 \\
Undergrad- Complete & 318 & 12,1 \\
Graduated- Specialization & 84 & 3,2 \\
Graduated- Master & 79 & 3,0 \\
Graduated- PhD & 207 & 7,9 \\
& & \\
Total & 2630 & 100,0 \\
\hline
\end{tabular}

\section{MARITAL STATUS}

As illustrated below, the majority of the sample declared to be single, followed by "other types of serious relationship" and married. A few declared to be divorced or widowed. 
Table 8 - Marital Status.

\begin{tabular}{lrr}
\hline & Frequency & Valid \% \\
\hline Married & 297 & 11,2 \\
Single & 1730 & 65,3 \\
Widowed & 3 & 0,1 \\
Divorced/Separated & 51 & 1,9 \\
Other type of serious & 569 & 21,5 \\
relationship & & \\
Total & 2650 & 100,0 \\
& & \\
\hline
\end{tabular}

\section{SEXUAL ORIENTATION}

Participants rated themselves on an equivalent of the Kinsey (1948) scale, in which they chose a number between 1 to 7 , with 1 representing exclusive heterosexuality, and 7 representing exclusive homosexuality. Number 4 represents the same proportion of heterosexuality and homosexuality, and 2-3 and 5-6 are intermediate scores, describing different degrees of bisexuality.

As illustrated in the Table 9, the majority of the sample declared to be exclusively or predominantly heterosexual, while a minority as bisexual or homosexual.

Table 9- Sexual Orientation (in scale)

\begin{tabular}{lrr}
\hline & Frequency & Valid \% \\
\hline Heterosexual exclusive & 1519 & 58,0 \\
2 & 477 & 18,2 \\
3 & 222 & 8,5 \\
Bisexual & 157 & 6,0 \\
5 & 48 & 1,8 \\
6 & 79 & 3,0 \\
Homosexual exclusive & 118 & 4,5 \\
& & \\
Total & 2620 & 100,0 \\
\hline
\end{tabular}


Taking into consideration the Transtheoretical Model of Behavior Change proposed by Prochaska and DiClemente (1983), physically active participants were classified into Action and Maintenance groups, respectively. Regarding sedentary participants, we did not offer options that allowed to classify them as more prone (Contemplation and Preparation stages) or not (Precontemplation stage) to start practicing PA.

Table 10 - Classification of participants according to Prochaska and DiClemente (1983) stages of behavior change.

\begin{tabular}{|c|c|c|}
\hline & Frequency & Valid \% \\
\hline $\begin{array}{l}\text { Action (until } 6 \\
\text { months) }\end{array}$ & 226 & 9,0 \\
\hline $\begin{array}{l}\text { Maintenance } \\
\text { (more than } 6 \\
\text { months) }\end{array}$ & 1076 & 42,7 \\
\hline Sedentary & 1219 & 48,4 \\
\hline Total & 2521 & 100,0 \\
\hline Not answered & 131 & 0,0 \\
\hline
\end{tabular}




\section{CHAPTER ONE- MOTIVATION FOR DIFFERENT PHYSICAL ACTIVITIES: A COMPARISON BETWEEN SPORTS, EXERCISES AND BODY/MOVEMENT PRACTICES*}

Rafael Ming Chi Santos Hsu, Jaroslava Varella Valentova

*Because we adopted the thesis format structured in a sequence of papers, they are presented here as the latest version (or published or accepted, when the case). This first chapter is composed by the article published in Psicologia USP7

\section{ABSTRACT}

Objective: Despite the well-known benefits for health, low levels of physical activity (PA) remain a public health issue. Research on motives for engaging in different PA shows differences in motives for Sports and Exercises. However, few studies addressed motives for practice of PA using more categories of PA. Methods: In this research, we investigated motives for four categories of PA (Individual Sports, Collective Sports, Exercises, and Body Practices), and possible effects of sex and age among 1,420 physically active individuals. Respondents answered the Motivation for Physical Activity Measure Revised. Results: Intrinsic motives were higher for Sports, while Exercisers were motivated more extrinsically. Body Practices, although being composed of several activities defined by previous studies as Exercises, showed a motivational pattern closer to Sports. Fitness/Health motivation increased with age, while Appearance motivation decreased. Regarding sex, women reported higher Interest/Enjoyment than men. Conclusions: Our results can have implications for physical activities promotion, especially considering more categories than Sports/Exercises in the context of different motives.

Keywords: Motivations; Sport; Exercise; Body/Movement Practice

\footnotetext{
7 Hsu, R. M. C. S., \& Valentova, J. V. (2020). Motivation for different physical activities: a comparison among sports, exercises and body/movement practices. Psicologia USP, 31. Also available at: $<$ https://www.researchgate.net/publication/344943800_Motivation_for_different_physical_activities_a_ comparison_among_sports_exercises_and_bodymovement_practices >
} 


\section{INTRODUCTION}

Research on motivation for physical activities (PA) commonly addresses the contrast between evidence for its mental and physical benefits, and evidence that a substantial portion of the population does not meet the standards of PA guidelines (e.g., Andrade Bastos et al., 2006; Ryan et al., 1997; Aaltonen et al., 2014). Studies on motivation for PA can shed some light on this paradox.

PA can be defined as a voluntary movement with energy costs superior to rest levels, aimed to attain some goal linked to Kinesiology dimensions (e.g., selfexpression, leisure, health and/or competition) (Caspersen et al., 1985; Hoffman and Harris, 2013). PA can be classified into specific domains, such as leisure, household, transportation and occupational (see, e.g., Florindo et al., 2009).

Among leisure time PA, a common classification splits PA into Sports and Exercises. Sport is a specific PA related to the use of skilled movement in game contexts, with attributes such as competition, rules, and search for records (Hoffman and Harris, 2013). Sports can be divided into Individual (e.g., tennis, karate, gymnastics) and Collective/Team (e.g., football, rugby, basketball, volleyball) (Gilet and Rosnet, 2008). Exercise (e.g., bodybuilding, jogging, walking, stretching, functional training), in turn, is a PA characterized as structured, repetitive movements aimed at enhancing physical fitness or conditioning (Caspersen et al., 1985).

Previous studies showed greater intrinsic motivation (refers to doing an activity for itself, and the pleasure derived from participation, Ryan and Deci, 2000b) for Sports and greater extrinsic motivation (directed at attaining or avoiding something outside the self) for Exercises (Frederick and Ryan, 1993; Ryan et al., 1997; Kilpatrick et al., 2005). Some studies showed that specific intrinsic motivation can be more frequent for specific PA. For example, collective sportists are motivated in particular by social reasons (e.g., Kilpatrick et al., 2005). Other studies showed differences in motivation for PA between men and women. Particularly, women are systematically more motivated than men by appearance (Apostolou and Lambrianou, 2017; Molanorouzi et al., 2015; Moreno Murcia, et al., 2007; Ryan et al., 1997; Frederick \& Ryan, 1993), while men more than women are motivated by sociality connected to PA (Apostolou and Lambrianou, 2017; Kilpatrick et al., 2005; Andrade Bastos et al., 2006). Motivation can also change with age. While Appearance motivation is stronger among younger 
individuals, Fitness/Health motivation increases with growing age (Apostolou and Lambrianou, 2017; Moreno Murcia et al., 2007; Andrade Bastos et al., 2006). Moreover, younger individuals report relatively higher Social, Competence, and Interest/Enjoyment motivation for PA (Apostolou and Lambrianou, 2017; Molanorouzi et al., 2015; Andrade Bastos et al., 2006).

Since the majority of previous studies have not compared more than two categories of PA, Frederick and Ryan (1993) suggested the importance of using a more detailed classification, because it could potentially better explain the dynamics of relationships among motivation and PA. Since then, however, to our knowledge, only a few attempts have been made toward more detailed classifications, such as Team Sport, Individual Racing plus Bowls, Racquet, Exercises, and Martial Arts (Molanorouzi et al., 2015). Other studies analyzed motivation for specific PA, showing for example higher intrinsic motivation for Taekwondo practitioners in comparison to Aerobics (Ryan et al., 1997). To our knowledge, no Brazilian study has yet analyzed motivations for more detailed categories of PA.

Besides, some previous classifications yielded criticism. For example, classifying Yoga in terms of modern PA dimensions has been criticized because of its occidentalization (Gnerre, 2010). Because Yoga includes many additional principles (e.g., spirituality, philosophy, historical traditions), the practioners and teachers do not accept Yoga to be categorized as an Exercise and even less as a Sport (e.g., Nunes, 2008). Similarly, it has been criticized to categorize dances as an exercise, and in general dancers do not fit themselves into Physical Education (see, for example, e.g., Brasileiro, 2009). Thus, there are still many PA that appear to not fit either sports or exercises.

\section{Aims and Hypotheses of the current study}

The main aim of the present study was to compare motivations of men and women among several different PA. We also tested possible effects of sex and age on motivations for the studied PA.

Based on previous literature (Kilpatrick et al., 2005; Frederick and Ryan, 1993; Ryan et al., 1997), we expected different motivations between practitioners of Sports and Exercises. In particular, Sport participants were expected to have more intrinsic motivations (Competence and Interest/Enjoyment) than exercisers, while Exercise participants would show more Appearance and Fitness/Health motivations than Sport 
participants. Social motivations were also expected to be higher in Sport practitioners. We further predicted that a separate category of PA, that do not meet the definition of both sports or exercises, would show a unique pattern of motivations. We followed previous literature which coined the term "Body Practice" to describe PA in ways that can be different from Sports and Exercises (see e.g., Lazarotti Filho et al., 2010) and we hypothesized that Body Practices would adopt an intermediary position in the motivations between Sports and Exercises.

We further expected higher Appearance and Fitness/Health motivations in women and more sociability in men.

Finally, we expected younger participants to report higher scores in Interest/Enjoyment and Appearance motivations, while older ones Fitness/Health motivations.

\section{METHODS}

\section{Participants}

Participants were recruited by convenience, through mailing lists to students, professors and other employees of a Brazilian university and also by polling the general public through social networks (Facebook and WhatsApp). The only requirement was to be 18 or more years old. Out of 2,652 respondents (mean age = $25.86, \mathrm{SD}=9.81$ ), we analyzed 1,420 who considered themselves as physically active (mean age $=26.83, \mathrm{SD}=10.49), 564$ men (mean age $=28.05, \mathrm{SD}=11.40)$ and 856 women (mean age $=25.98, S D=9.70$ ). A t-test has shown a significant age difference between men and women, with men being significantly older than women $(t(2)=4.804$, $p<0.001)$.

\section{Instruments}

This study is part of a broader project aimed at relations between personality and motivations for PA. The research consisted of several standardized questionnaires, and here we report instruments relevant only for this specific study.

The participants completed a basic sociodemographic questionnaire, and indicated the activity they most practiced and the time of practice. Based on this information, activities were classified by the first author as: Individual Sport, Collective Sport or Exercise. An additional category- Body Practice- was created, to group, by 
exclusion of PA that either do not meet clearly the definitions of Sports (eminently competitive) or Exercises (emphasizing physical conditioning), such as Yoga, Pilates, Tai Chi Chuan, Liang Gong, dances, and Gymnastics for All.

As shown in Table 1.1, a larger proportion of participants declared Exercise as the primary leisure-time PA. Table 1.2 also shows all activities considered for the research and their respective categorization into the four categories.

The participants further filled in the Motivation for Physical Activity Measure Revised (Ryan et al., 1997) that measures, in 30 items answered on 7-point likert scales, five motivational factors related to PA: intrinsic (Interest/Enjoyment, Competence) and extrinsic (Fitness/Health, Appearance, Social). The internal consistency measured by Cronbachs' alphas were: Interest/Enjoyment $(\alpha=.92)$; Competence $(\alpha=.90)$; Appearance $(\alpha=.89)$; Fitness/Health $(\alpha=.80)$ and Social $(\alpha=$ $.85)$.

Table 1.1 Distribution of types of physical activities

\begin{tabular}{|c|c|c|c|c|c|c|}
\hline & $\begin{array}{c}\text { Total } \\
\mathrm{N}\end{array}$ & $\%$ & $\begin{array}{c}\text { Men } \\
\mathrm{N}\end{array}$ & $\%$ & Women N & $\%$ \\
\hline Individual Sport & 281 & 19.6 & 141 & 25.0 & 137 & 16.0 \\
\hline Collective Sport & 243 & 17.0 & 107 & 19.0 & 134 & 15.7 \\
\hline Exercise & 721 & 52.9 & 291 & 51.7 & 423 & 49.5 \\
\hline Body Practice & 186 & 10.6 & 24 & 4.3 & 160 & 18.7 \\
\hline Total (sample) & 1431 & 100.0 & 563 & 100.0 & 854 & 100.0 \\
\hline
\end{tabular}

Table 1.2 All physical activities indicated by participants and their respective categorization into the four categories (Exercise, Individual Sport, Collective Sport, Body Practices)

\begin{tabular}{|l|lll|}
\hline Category & \multicolumn{3}{|c|}{ Physical Activities } \\
\hline Exercise & Exercises at gym- 334 & Bycicling/Bike- 21 & Dogs (activities with) \\
& (Strength- 297, Crossfit- & Functional training- 16 & Hiit \\
& 17; Aerobics- 13; & Gymnastics- 11 & Horse riding \\
& Spinning- 5, Jumping; & Hydrogymnastics- 8 & Labor gymnastics \\
& Localized) & Calisthenics- 3 & Morphofunctional \\
& Running- 147 & Body pump- 2 & training (Menegatti) \\
& Walking- 89 & Fitness- 2 & Stretching \\
& (general- 88, simulator- & Jump rope- 2 & Tae Bo \\
& 1) & Body jump & Trekking \\
& Exercises (other)- 59 & Deep running & Virtual gym \\
& (not specified- 51; At & & \\
\hline
\end{tabular}




\begin{tabular}{|c|c|c|c|}
\hline & $\begin{array}{l}\text { home- 4; Without } \\
\text { weights - } 2 \text {; For } \\
\text { column, Physical } \\
\text { conditioning) }\end{array}$ & & \\
\hline $\begin{array}{l}\text { Individual } \\
\text { Sport } \\
(\mathrm{n}=281)\end{array}$ & $\begin{array}{l}\text { Martial Arts- } 96 \\
\text { (Kung fu- 18, Karate- } \\
\text { 15, Muay Thay- 14, } \\
\text { Boxing- 9, Jiu-jitsu- 8, } \\
\text { Judo- 8, not specified- } \\
\text { 7, Taekwondo- 5, } \\
\text { Capoeira- 4, Krav } \\
\text { magá- 3, Kendo- 2, } \\
\text { Fencing, Hapkido), } \\
\text { Swimming- 68 } \\
\text { (not specified- 67; high } \\
\text { performance- 1), } \\
\text { Racquet- 40 } \\
\text { (Tennis- 28, Table } \\
\text { tennis- 9, Badminton- 3) }\end{array}$ & $\begin{array}{l}\text { Cycling- } 27 \\
\text { Athletics- } 26 \\
\text { Pole dance- } 12 \\
\text { Road running- } 7 \\
\text { Weightlifting- } 4 \\
\text { Climbing- } 2 \\
\text { Roller- } 2 \\
\text { Surf- } 2\end{array}$ & $\begin{array}{l}\text { Acrobatic gymnastics } \\
\text { Archery } \\
\text { Breaking dance } \\
\text { Kettlebell lifting } \\
\text { Pole sport } \\
\text { Skate } \\
\text { Triatlon }\end{array}$ \\
\hline $\begin{array}{l}\text { Collective } \\
\text { Sport }(n= \\
243)\end{array}$ & $\begin{array}{l}\text { Foot- } 84 \\
\text { (Futsal- 47, Soccer- 37) } \\
\text { Volleyball- } 43 \\
\text { Handball- } 33 \\
\text { Basketball- } 32\end{array}$ & $\begin{array}{l}\text { Rugby- } 19 \\
\text { Boat- } 11 \\
\text { (Rowing- 9, Canoeing- } \\
\text { 2) } \\
\text { Baseball- } 5 \\
\text { American football- } 4\end{array}$ & $\begin{array}{l}\text { Cheerleading- } 3 \\
\text { Softballl- } 3 \\
\text { Water polo- } 2 \\
\text { Ultimate frisbee }\end{array}$ \\
\hline $\begin{array}{l}\text { Body } \\
\text { Practices } \\
(n=186)\end{array}$ & $\begin{array}{l}\text { Dance- } 81 \\
\text { (General- 32, Ballet- 24, } \\
\text { Belly dance- 5, Zumba- } \\
\text { 5, Jazz- 4, Tai Ko- 4, } \\
\text { Ballroom dance- 2, Tap } \\
\text { dance- 2, Contemporary } \\
\text { dance, German folk } \\
\text { dance, Urban dance) } \\
\text { Pilates- } 54 \\
\text { Yoga- } 26\end{array}$ & $\begin{array}{l}\text { Circus- } 4 \\
\text { Parkour- } 3 \\
\text { Aikido- } 2 \\
\text { Tai Chi Chuan } \\
\text { Taisou }\end{array}$ & $\begin{array}{l}\text { Aerial silk } \\
\text { Ashtanga } \\
\text { Equitation } \\
\text { Holistic Gymnastics } \\
\text { Pi-Yo }\end{array}$ \\
\hline
\end{tabular}

\section{Procedure}

Data were collected online using Qualtrics software (Qualtrics, Provo, UT). All participants first read the consent form and, by clicking confirmed their anonymous 
participation in the study, taking, on average, $25 \mathrm{~min}$. No reward was provided for participating in the study. The project was approved by the IRB of Institute of Psychology, University of São Paulo (number 1.506.899, approved on April 19th, 2016).

\section{Statistical Analyses}

Analyses were conducted with Statistical Package for Social Sciences (SPSS) version 21.0.

To test for effect of type of PA, sex and age on motivations, we performed Multivariate General Linear Models (GLM) with type of motivation as dependent variable, while type of PA (Individual Sport, Collective Sport, Body Practice, Exercise) and sex entered as fixed factors. Age entered as a covariate. Test of Between-Subject Effects was further checked to estimate the main effects, and Estimated Marginal Means with Bonferroni correction were consulted as post-hoc tests. All effect sizes are reported in partial eta square $\left(\eta_{p}^{2}\right)$.

\section{RESULTS}

\section{Effect of type of physical activity, sex and age on motivation for physical activity}

GLM showed significant effects of type of PA- Individual Sport, Collective Sport, Exercise and Body Practice [Wilks' Lambda $=.637, \mathrm{~F}(3,4)=45.384, \mathrm{p}<.001$.], age [Wilks' Lambda $=.944, F=16.47, p<.001]$, and sex [Wilks' Lambda $=.993, F(1,2)=$ $2.440, p=.033]$.

As illustrated in Table 1.3, Interest/Enjoyment motivation was the highest for Collective Sports than all the other types of PA (all p's < .033), while Exercise scored the lowest on this motivational dimension (all p's $<.001$ ). Individual Sports and Body Practices did not differ from each other $(p=.510)$.

In the Competence dimension of motivation, Individual and Collective Sports did not differ from each other $(p=1.00)$, and Body practice also did not differ from either individual Sport $(p=.378)$ or Collective Sport $(p=.261)$. Both Sports and Body Practice scored higher than Exercises (all p's < .049).

Appearance was the most important motivation for Exercise that differed from the three other types of PAs (all p's $<.001$ ). Appearance motivation was higher in 
Individual Sport than Collective Sport $(\mathrm{p}=.003)$, and Body Practice did not differ either from Individual Sport $(p=.288)$ or Collective Sport $(p=1.000)$.

Fitness/Health was the second most important motivation for Exercise that differed from the three other types of PAs (all p's < .001). Fitness/Health motivation was higher in Individual Sport than Collective Sport $(p<.001)$, and Body Practice did not differ either from Individual Sport $(p=.105)$ or Collective Sport $(p=1.000)$.

Social motives were the strongest for Collective Sports that differed from the three other types of PAs (all p's < .001). In sequence, Individual Sports scored higher than both Exercises $(p<.001)$, but not Body Practices $(p=.572)$. Body Practices also scored higher than Exercises $(p<.001)$.

Table 1.3 Differences between mean scores $( \pm S D)$ of motivational dimensions divided among four types of Physical Activities

\begin{tabular}{cccccc}
\hline & $\begin{array}{c}\text { Individual } \\
\text { Sport- Mean } \\
(\mathrm{SD})\end{array}$ & $\begin{array}{c}\text { Collective } \\
\text { Sport- } \\
\text { Mean (SD) }\end{array}$ & $\begin{array}{c}\text { Exercise- } \\
\text { Mean (SD) }\end{array}$ & $\begin{array}{c}\text { Body Practice- } \\
\text { Mean (SD) }\end{array}$ & $\begin{array}{c}\text { F } \\
\text { statisti } \\
\text { cs }\end{array}$ \\
\hline Interest/Enjoyment & $5.90(.077)^{2}$ & $6.23(.085)^{1}$ & $4.94(.050)^{3}$ & $5.63(.142)^{2}$ & $\begin{array}{r}67.29^{*} \\
*\end{array}$ \\
Competence & $5.29(.092)^{1}$ & $5.33(.101)^{1}$ & $4.46(.059)^{2}$ & $4.93(.168)^{1}$ & $28.00^{*}$ \\
Appearance & $4.36(.090)^{2}$ & $3.90(.098)^{3}$ & $5.32(.058)^{1}$ & $3.99(.164)^{2,3}$ & $\begin{array}{r}63.67^{*} \\
*\end{array}$ \\
Fitness/Health & $5.73(.066)^{2}$ & $5.31(.072)^{3}$ & $6.05(.042)^{1}$ & $5.40(.121)^{2,3}$ & $25.85^{*}$ \\
Social motivation & $3.15(.082)^{2}$ & $4.21(.090)^{1}$ & $2.21(.053)^{3}$ & $2.86(.151)^{2}$ & 122.5 \\
& & & & & $9^{* *}$
\end{tabular}

Means $( \pm S D)$ with the same uppercase letters do not differ from each other (using Bonferroni's posthoc comparisons). ${ }^{* *} \mathrm{p}<.001$

Further, Sex appeared as a significant predictor of the Interest/Enjoyment for physical activities with women showing higher Interest/Enjoyment than men (mean difference $=.217, \mathrm{SE}=.095, \mathrm{p}=.022$ ). There was no other effect of sex.

Moreover, there was a negative correlation between age and Appearance motives $(r=-.054, p=0.042)$, while a positive with Fitness/Health $(r=.125, p<.001)$

Finally, considering the participants as a whole, the means reported for motivations were Fitness/Health $(5.79, S D=1.15)$, followed by Interest/Enjoyment 
(5.47, SD = 1.40), Competence (4.84, SD = 1.58), Appearance (4.73, SD = 1.62) and Social $(2.79, S D=1.56)$. A univariate ANOVA showed significant differences among all these motivation types (all p's < .001), with exception of Competence and Appearance which did not differ from each other $(p=.32)$.

\section{Differences in self-reported practice of PA among sexes and Relations between Age and Type of PA}

To analyze if sex was related to practice or not of PAs, a Chi-Square test was made. We found significant sex difference in prevalence of practice $\left(x^{2}(1,2)=10.175\right.$, $p=0.001$, Cramer's $V=0.062$ ), as reported by participants. A greater proportion of men (564 of 971 , or $58.08 \%$ ) declared practicing a PA regularly in leisure time, than women ( 856 of 1657 , or $51.66 \%$ ).

To analyze if there were relations between Sex and Type of PA, a Chi-Square test was conducted. The test showed significant associations $\left(x^{2}(3,4)=71.252, p<\right.$ 0.001 , Cramer's $V=0.224)$. As illustrated in Table 1.4, there was a greater proportion of men among the physically active in Sports (mainly Individual, 50.7\%), while a greater proportion of women reported a Body Practice (87.0\%) as their main type of PA.

Table 1.4 Cross tabs between type of physical activity and participant's sex

\begin{tabular}{|c|c|c|c|c|c|c|}
\hline & & \multicolumn{4}{|c|}{ Type of physical activity } & \multirow[t]{2}{*}{ Total } \\
\hline & & $\begin{array}{l}\text { Individual } \\
\text { Sport }\end{array}$ & $\begin{array}{c}\text { Collective } \\
\text { Sport }\end{array}$ & Exercise & $\begin{array}{c}\text { Body } \\
\text { Practice }\end{array}$ & \\
\hline Participant's & Male & $\begin{array}{c}141 \\
(50.72 \%)\end{array}$ & $\begin{array}{c}107 \\
(44.40 \%)\end{array}$ & $\begin{array}{c}291 \\
(40.76 \%)\end{array}$ & $\begin{array}{c}24 \\
(13.04 \%)\end{array}$ & $\begin{array}{c}563 \\
(39.73 \%)\end{array}$ \\
\hline sex & Female & $\begin{array}{c}137 \\
(49.28 \%)\end{array}$ & $\begin{array}{c}134 \\
(55.60 \%)\end{array}$ & $\begin{array}{c}423 \\
(59.24 \%)\end{array}$ & $\begin{array}{c}160 \\
(86.96 \%)\end{array}$ & $\begin{array}{c}854 \\
(60.27 \%)\end{array}$ \\
\hline Total & & $\begin{array}{c}278 \\
(100.00 \%)\end{array}$ & $\begin{array}{c}241 \\
(100.00 \%)\end{array}$ & $\begin{array}{c}714 \\
(100.00 \% \\
)\end{array}$ & $\begin{array}{c}184 \\
(100.00 \% \\
)\end{array}$ & $\begin{array}{c}1417 \\
(100.00 \\
\%)\end{array}$ \\
\hline
\end{tabular}

We also looked to see if participants were differentially distributed according to age categories (18-30 and over 30 years) in different types of PAs. A Chi-Square test showed significant associations $\left(x^{2}(3,4)=33.518, p<0.001\right.$, Cramer's $\left.V=0.153\right)$. In comparison to other types of PA, a smaller proportion of persons over 30 years $(7 \%)$ 
was involved primarily in Collective Sport, while in other types of PA, people over 30 years ranged from $22.8 \%$ to $25.3 \%$

\section{DISCUSSION AND CONCLUSIONS}

This study investigated influences of type of physical activity (Collective and Individual Sports, Exercises, and Body Practices, sex and age on motivations for physical activities (PAs). Similar to previous reports (Kilpatrick et al., 2005; Ryan et al., 1997; Frederick and Ryan, 1993), Interest/Enjoyment, Competence (intrinsic motivations), and Social motives were higher for Sports, in particular Collective in comparison to Exercises. Exercisers, on the contrary, were motivated more by Appearance and Fitness/Health (extrinsic motivations). Body Practices, in turn, although being composed of several activities frequently defined as Exercises by previous studies, showed a motivational pattern closer to Sports (especially Individual, as both did not differ in any motive). Particularly in Appearance and Fitness/Health motivations, where Exercises have the highest scores, Body Practices don't differ from both types of Sports. In all other subscales, Body Practices differed from Exercises.

To our knowledge, the present study is the first to show a distinct motivational pattern among different types of PA, when considering Body Practices as a distinct category, besides Sports and Exercises. Body Practice can be defined as a kind of activity based on gestuality, expression and care, in which the practice serves to selfcare and also for care of others (Alves and Carvalho, 2010; Carvalho, 2006). Our results seem to support such definition. Interestingly, although Sports were more prevalent among men and Body Practices among women, both showed higher intrinsic motivations than Exercises, practiced similarly by both men and women.

Despite our results, further research is still needed to confirm whether there is sufficient support for considering Body Practice as a consistent category of PA. For example, there are overlaps between the categories, because some activities can transit between two or more categories or just have an intermediate pattern (see Figure 1.1). For example, a sport practiced more for social than competitive motives meets the Body Practice definition and can be placed at intersection between Sports and Body Practices. Similarly, Pilates was classified as a Body Practice but because of its structured series of repetitive exercises, it falls in the intersection between Body Practice and Exercise. Halterophilism, for example, consists of exercises, however is 
performed under competitive, that is, sportive, settings, thus fitting the intersection between Sport and Exercise. Also, swimming can be practiced as a mere weight loss exercise, an Individual Sport or even a Body Practice, depending upon the personal reasons involved. Thus, even an activity with attributes of all three PA's can exist, according to the context.

Figure 1.1

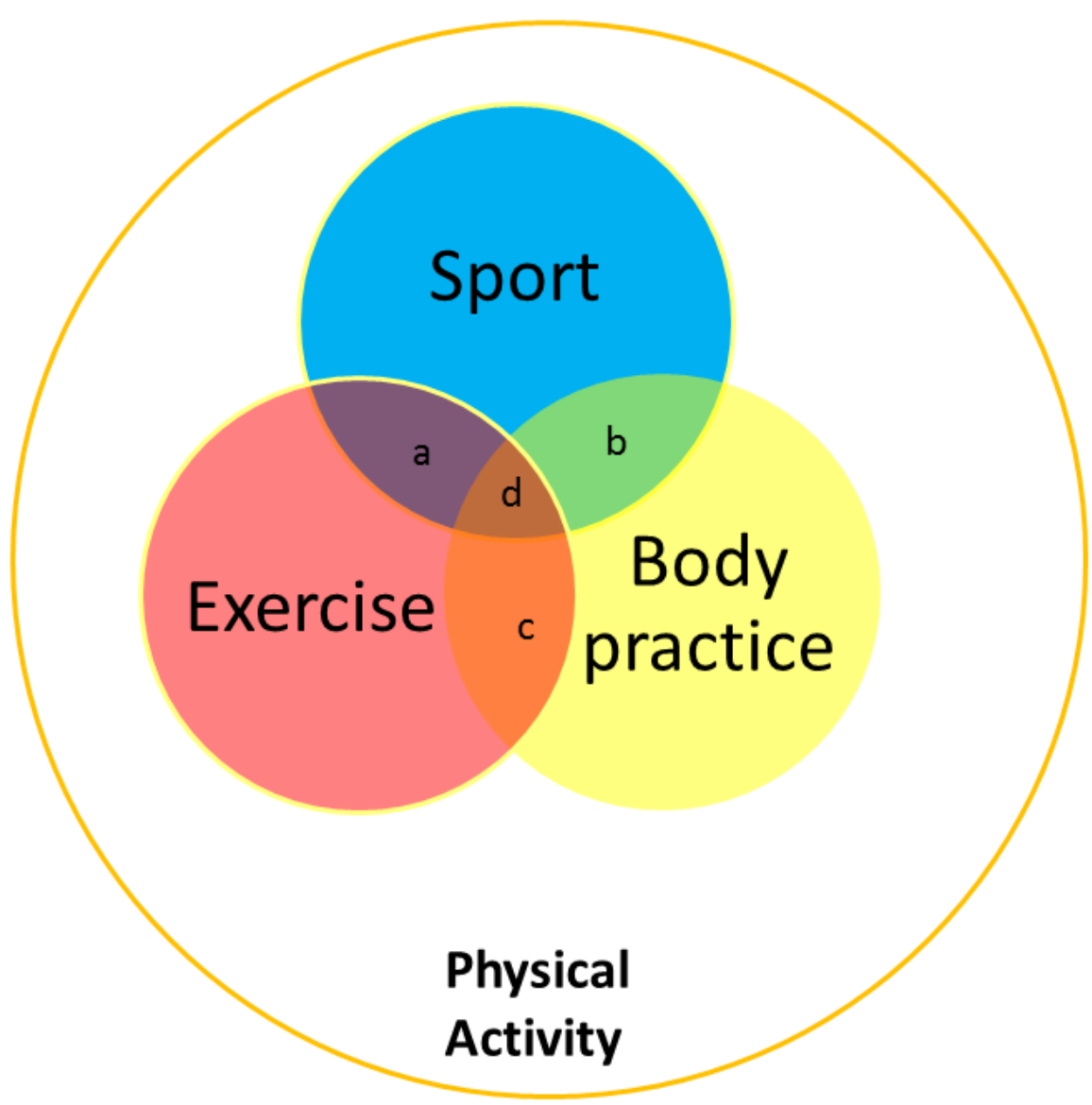

Regarding sex, we found a difference in motivations for PAs: women reported higher Interest/Enjoyment motives than men. Previous studies reported higher Appearance motivation among women than in men (Apostolou and Lambrianou, 2017; Molanorouzi et al., 2015; Ryan et al., 1997; Frederick and Ryan, 1993). This result can be culturally specific, as previous studies on Brazilian population also did not find sex difference in Appearance motivation (Andrade Bastos et al., 2006; Gonçalves and Alchieri, 2010). The result in our sample can be caused by a higher appearance 
preoccupation in Brazilian men (mean $=4.73$ ), in comparison to other countries (e.g., mean $=4.44$ among Spanish men) (Murcia et al., 2007). Similarly, higher Social motivation was expected among men (Apostolou and Lambrianou, 2017; Deaner et al., 2016), which was found also among Brazilian men (Andrade Bastos et al., 2006). Although we did not encounter any sex difference, social motivations were more important for Sports (in particularly collective) which was more prevalent among men.

The low sex differences in our sample can also be explained by the majority of university participants, where gender inequality is lower than in general society, although still prevalent (e.g., Valentova et al., 2017).

Importantly, we asked participants to rate items based on their primary PA (the most practiced), similarly to Frederick and Ryan (1993), whereas majority of the previous studies asked about preferred PA or they do not specify. This can generate different results among the studies. For example, one can prefer some kind of PA (e.g., golf) but doesn't have sufficient income to do it frequently, so in the end he/she does most frequently some other activity that may not be as liked as the preferred one. Future studies can explore this issue more, by asking participants to respond about both the most liked PA and the most practiced one.

In line with previous studies, a greater proportion of men than women reported doing some type of PA regularly. In particular, the relative proportion of men in sports, mainly Individual, surpassed that of women, which can be analysed through an evolutionary lens. In hunter-gatherer societies, consistently more men engage in hunt and war (see Apostolou and Shialos, 2018), activities closely similar to Sports, while women are more engaged in gathering foods, which is more similar to Body Practices, defined by a great care/nurture (Carvalho, 2006). Even in contemporary societies, men are more engaged and enjoy hunting and women enjoy more gathering (Apostolou and Shialos, 2017). Regarding Exercises, considering, for example, the necessity to run in extreme situations for both sexes, it is reasonable to expect equilibrium in Exercises prevalence. Our results are also very similar to Cardoso's (in press) construct of motor orientation, which proposes a greater combativeness orientation in men, while a greater rhythmicity for women. Combativeness is very present in many sports, which were more practiced by men, while rhythmicity is present in several artistic body practices, such as dances, mainly practiced by women.

Finally, comparing the motives with each other, particularly interesting is the low Social motivation (with an exception to Collective Sports). This finding is similar with 
previous studies (e.g., Alltonen et al., 2016; Apostolou and Lambrianou, 2017; Ryan et al., 1997), and suggests that, in general, people may value more other ways to socialize than through PAs. On the other hand, Fitness/Health seems to be the most inspiring for practicing PAs, which can reflect conscience of people about health benefits that PAs offer. This is in line with the positive correlation between age and Fitness/Health motivation, as chronic diseases commonly manifest more with increasing age (see Kennedy et al., 2014) and PA is a strong protection factor (see Durstine et al., 2014).

Although the categorization into Sports, Exercises, and Body Practices was an attempt toward a better comprehension of PA participation, this may have resulted in simplification and loss of differences within the categories. For example, Andrade Bastos et al. (2006) found differences in motivations comparing participants of fitness programs and walkers, who in our study were analyzed together as Exercise participants. Future studies could address this issue more thoroughly and see which specific activities are more similar in motivations despite the broader category. Another possibility is to test motives using other criteria for classification of PAs, such as motor/sportive orientation (Gill and Deeter, 1988; Cardoso, in press), or even more perceptual and motor criteria, such as task complexity (e.g., Naylor and Briggs, 1963).

Our classification can have practical implications, since the motivational profile could be compared with each person's preferences and past experiences with PAs to give advice toward the practice of other types of PAs. Another possibility is to emphasize more intrinsic motives during interventions. Although extrinsic motives are not necessarily negative, since they vary in degree of autonomy (Ryan and Deci, 2000b; Batia, 2007), and also are good reasons for initiation in PAs, intrinsic motivations reflect more autonomous, self-determined behaviors and are more related to adherence, deliberate practice and engagement, and also positive responses (Ryan et al., 1997; Batia, 2007; Vink and Raudsepp, 2018; Vink et al., 2015).

Future studies might also include personality into the model of motivations for different types of PAs. This could help to a better understanding of the phenomenon, partially because PAs can have a strong self-presentational component (see Howle et al., 2015), similar to social networking sites, and research shows several interesting relationships among social networking sites and personality (e.g., for Facebook, Marshall et al., 2015; and for Tinder, Timmermans and Caluwé, 2017). Also, it would be of interest to test if time of practice has an effect on motivation i.e., if a group that 
practices for more time has more intrinsic motivations in comparison to one that practices for less time. Recent research suggests such a possibility (e.g., Larson et al., 2018). Such variables could also be compared controlling for education (e.g., undergraduates vs graduates), since there is evidence for difference in intrinsic motives according to level of education (Sevil et al., 2018). Future studies may also integrate motivational analyzes with perceived health barriers to PA practice (e.g., Warnet et al., 2017).

This is the first empirical test of a categorization of PAs into Sports, Exercises and Body Practices. Our findings regarding distinct patterns of intrinsic and extrinsic motivations for the three categories suggest their relative independence. As shown by Carvalho and Manoel (2015), Body Practices have been almost exclusively studied through the lens of social sciences, such as Collective Health. Thus, the present study also contributed to fill this gap, by adding an evolutionary approach, and also by testing potential differences in motivations with a classification of PAs that included Body Practices as a distinct category from Sports and Exercises

However, we suggest the need of a more operational definition for Body Practices to avoid confusions. Future studies may address this by focusing more on comparing different methods of classification, taking into account aspects, such as relative intensity (as proposed by the Compendium of Physical Activities, Ainsworth et al., 2011), motor orientation (e.g., Cardoso, in press), or a data driven classification, by grouping PAs according to statistical criteria.

In summary, we tested a classification of physical activities divided into Individual Sports, Collective Sports, Exercises, and Body Practices. Our results showed different patterns of motivational profiles according to each type of physical activity. Therefore, the present classification should be considered in future research of psychology of physical activities.

\section{ACKNOWLEDGEMENTS}

We would like to thank Professor Jerry Hogan for the English proofreading, and Irene Delval for the abstract translation to Spanish. We also would like to acknowledge Cristina Landgraf Lee, Renata Pereira de Felipe, Fernando Luiz Cardoso, Patrícia Izar, Anthonieta Looman Mafra, Michele Schultz for comments and suggestions on 
previous versions. Finally, thanks for all participants, people that shared the survey and also members of Evolution, Behavior and Sexuality Lab for all support. Research Grant \#2016/22964-0 and Research Grant \#2018/13937-4, São Paulo Research Foundation (FAPESP).

\section{Declaration of Conflicting Interests}

The Authors declare that there is no conflict of interest.

\section{REFERENCES}

Aaltonen S., Kujala UM., Kaprio J. (2014) Factors behind leisure-time physical activity behavior based on Finnish twin studies: The role of genetic and environmental influences and the role of motives. BioMed research international 931820: 1-8. Ainsworth BE, Haskell WL, Herrmann SD, et al. (2011) 2011 Compendium of Physical Activities: a second update of codes and MET values. Medicine \& science in sports \& exercise 43(8): 1575-1581.

Alves F, Carvalho Y. (2010) Práticas corporais e grande saúde: um encontro possível. Movimento (ESEF/UFRGS) 16(4): 229-244.

Andrade Bastos A, Salguero A, González-Boto R, et al. (2006) Motives for participation in physical activity by Brazilian adults. Perceptual and Motor Skills 102(2): 358-67.

Apostolou M, Lambrianou R (2017) What Motivates People to Do and Watch Sports? Exploring the Effect of Sex, Age, Partner Status, and Parenthood. Evolutionary Psychological Science 3(1): 20-33.

Batia A (2007) Relationships among personality, self-determination and exercise behavior. Doctoral Dissertation, University of Florida, US.

Brasileiro LT (2009) Dança - educação fisica: (in)tensas relações. Doctoral Dissertation- Universidade Estadual de Campinas, BR.

Cardoso FL (in press) A Vivência de Práticas Físicas/Motoras/Esportivas de Homens e Mulheres para Propor o Construto Orientação Esportiva. Revista Brasileira de Educação Física e Esporte. 
Carvalho YM (2006) Promoção da saúde, práticas corporais e atenção básica. Revista Brasileira Saúde da Família 7(11): 33-45.

Carvalho YM, Manoel EJ (2015) A survey of body practices and primary health care in a district of São Paulo, Brazil. Motriz: Revista de Educação Física 21(1): 7583.

Caspersen CJ, Powell KE, Christenson GM. (1985) Physical activity, exercise, and physical fitness: definitions and distinctions for health-related research Public health reports: 100(2), 126-131.

Deaner RO, Balish SM, Lombardo MP (2016) Sex differences in sports interest and motivation: An evolutionary perspective. Evolutionary Behavioral Sciences 10(2): 73-97.

Florindo AA, Guimarães VV, Cesar CLG, et al. (2009) Epidemiology of leisure, transportation, occupational, and household physical activity: prevalence and associated factors. Journal of Physical Activity and Health 6(5): 625-632.

Frederick C, Ryan RM (1993) Differences in motivation for sport and exercise and their relations with participation and mental health. Journal of Sport Behavior 16(3): 124-146.

Gillet N, Rosnet E. (2008) Basic need satisfaction and motivation in sport. The online journal of sport psychology 10(3).

Gnerre MLA (2010) Identidades e paradoxos do Yoga no Brasil: Caminho espiritual, prática de relaxamento ou atividade física? Fronteiras 12(21): 247-270.

Gonçalves MP, Alchieri JC (2010) Motivação à prática de atividades físicas: um estudo com praticantes não-atletas. Psico-USF 15(1): 125-134.

Hoffman SJ, Harris JC (2013) Introduction to Kinesiology. In: Hoffman, S. J.

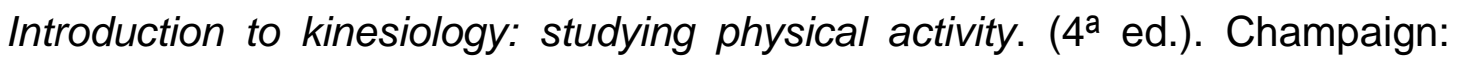
Human Kinetics.

Kennedy BK, Berger SL, Brunet A, et al. (2014) Geroscience: linking aging to chronic disease. Cell 159(4): 709-713.

Kilpatrick M, Hebert E, Bartholomew J (2005) College students' motivation for physical activity: differentiating men's and women's motives for sport participation and exercise. Journal of American college health 54(2): 87-94.

Larson HK, McFadden K, McHugh TLF, et al. (2018) When you don't get what you want-and it's really hard: Exploring motivational contributions to exercise dropout. Psychology of Sport and Exercise 37: 59-66. 
Lazzarotti Filho A, Silva AM, Antunes PDC, et al. (2010) O termo práticas corporais na literatura científica brasileira e sua repercussão no campo da Educação Física. Movimento 16(1): 11-29.

Marshall T, Lefringhausen K, Ferenczi N (2015) The Big Five, self-esteem, and narcissism as predictors of the topics people write about in Facebook status updates. Personality and Individual Differences 85: 35-40.

Molanorouzi K, Khoo S, Morris T (2015) Motives for adult participation in physical activity: type of activity, age, and gender. BMC public health 15(1): 1-12.

Murcia JAM, Gimeno EC, Camacho AM (2007) Validación de la Escala de Medida de los Motivos para la Actividad Física-Revisada en españoles: Diferencias por motivos de participación. Anales de psicología 23(1): 167-176.

Naylor JC, Briggs GE (1963) Effects of task complexity and task organization on the relative efficiency of part and whole training methods. Journal of Experimental Psychology 65(3): 217.

Nunes TDCL (2008) Yoga: do corpo, a consciência; do corpo à consciência. O significado da experiência corporal em praticantes de yoga. Master Thesis, Universidade Federal de Santa Catarina, BR.

Pelletier LG, Tuson KM, Fortier MS, et al. (1995) Toward a new measure of intrinsic motivation, extrinsic motivation, and amotivation in sports: The Sport Motivation Scale (SMS). Journal of Sport and Exercise Psychology 17(1): 35-53.

Ryan RM, Deci EL (2000) Self-determination theory and the facilitation of intrinsic motivation, social development, and well-being. American Psychologist 55(1): 68-78.

Ryan RM, Frederick C, Lepes D, et al. (1997) Intrinsic motivation and exercise adherence. International Journal of Sport Psychology 28(4): 335-354.

Sevil J, Sánchez-Miguel PA, Pulido JJ, et al. (2018) Motivation and Physical Activity: Differences Between High School and University Students in Spain. Perceptual and motor skills 125(5): 894-907.

Valentova JV, Otta E, Silva ML, et al (2017) Underrepresentation of women in the senior levels of Brazilian science. PeerJ 5 e4000: 1-20.

Vink K, Raudsepp L (2018) Perfectionistic Strivings, Motivation and Engagement in Sport-Specific Activities Among Adolescent Team Athletes. Perceptual and motor skills 125(3): 596-611. 
Vink K, Raudsepp L, Kais K (2015) Intrinsic motivation and individual deliberate practice are reciprocally related: Evidence from a longitudinal study of adolescent team sport athletes. Psychology of Sport and Exercise 16: 1-6.

Warner, LM, Wolff, JK, Spuling, SM, et al. (2017) Perceived somatic and affective barriers for self-efficacy and physical activity. Journal of Health Psychology 24(13): 1850-1862. 


\section{CHAPTER TWO- COMPARING DIFFERENT TYPOLOGIES OF PHYSICAL ACTIVITIES WITH FOCUS ON MOTIVATION*}

Rafael Ming Chi Santos Hsu1*, Fernando Luiz Cardoso 2, Marco Antonio Corrêa Varella $^{1}$, Edvane Marlene Pires ${ }^{3}$, Jaroslava Varella Valentova ${ }^{1}$

Submitted to Frontiers in Psychology (October, 06, 2021)

1Evolution, Behavior and Sexuality Lab, Institute of Psychology, Department of Experimental Psychology, University of São Paulo, São Paulo, Brazil

${ }^{2}$ Centre of Physical Education, Physiotherapy and Sports, State University of Santa Catarina, Florianópolis

${ }^{3}$ Psychological Orientation Nucleus, Police Academy, Civil Police of São Paulo, São Paulo, Brazil

* Correspondence:

Corresponding Author

rafa.mcsh@gmail.com

\section{ABSTRACT}

Different classifications of physical activities (PA) exist, however they lack precise grouping criteria and tend to vary according to each author. Among other factors, individual level of motivation is considered an important aspect for to PA maintenance. In this research, we aimed to (1) compare several PAs according to intrinsic (Interest/Enjoyment and Competence) and extrinsic (Appearance, Fitness/Health and Social) motives, and (2) to analyse PAs with and without previous grouping, to explore which PAs would be more similar according to the different motivational subscales. We recruited 1,421 physically active Brazilian participants (mean age $=26.83, \mathrm{SD}=$ 10.49), who stated themselves as physically active. Among the main results, we found that some PAs were consistently separated themselves from others on regarding motivational subscales. For example, such as participants practicing Walking showed less Interest/Enjoyment and Competence than several other PAs. Pilates was marked highlighted by a particularly low Social motivation compared to other PAs. Further, using different categorization of PAs suggested by previous authors also showed 
consistent distinctions considering each motivational subscale. Specifically, one group of PA scored higher than the others on intrinsic motivation (e.g., PA more Complex, Team, Vigorous, Hybrid, and Combative), and the reverse was found when considering Appearance and Fitness/Health motives (e.g., PA more Organized, Individual, Moderate, Strength, and Rhythmic). Our results thus provide initial evidence toward possible new methods of grouping PA types that can improve maintenance behavior, using motivation as a grouping factor.

Keywords: motivation, psychology, physical activity, classification, movement, health.

\section{INTRODUCTION}

Several classification systems were proposed to group, differentiate, and organize physical activities. Physical activity (PA) can be divided according to context, such as leisure, commuting, household and work (Streb et al., 2019). Leisure-time PAs are commonly sub-classified into sports and exercises, and each of them can be further subdivided. For example, sports can be individual or team sports (e.g., Molanorouzi, Khoo\& Morris, 2015), while exercises can be divided according to resistance, flexibility, endurance, balance, etc. (Caspersen, Powell \& Christensen, 1985).

Intensity of energy expenditure can also categorize PA into light, moderate or vigorous (Ainsworth et al., 2011). PA can further be divided into aerobic or anaerobic, according to metabolic requirements (U.S. DHHS, 1996). In the Compendium of Physical Activities, Ainsworth et al. (2011) use a heading to group types of PA, each sub-classified according to metabolic equivalents of effort/energy expenditure. For example: sexual activity - passive, general or active; dance - aerobic, ballroom, ballet, etc.; sports - tennis, badminton, karate, volleyball, etc; conditioning exercises calisthenics, stretching, resistance training, etc.

In Brazil, Cardoso et al. (2020), proposed a system that classifies PAs as predominantly oriented by either combativeness or rhythmicity. The authors define combativeness as PAs with high physical contact and competition, while rhythmicity are PAs involving music and dance. This classification varies with individual sex and sexual orientation. Heterosexual men and homosexual women were more prone to football, a more combative PA, whereas heterosexual women and homosexual men reported to be more prone to ballet, a more rhythmic PA (Cardoso et al., 2020). 
Another classification considered in the field of motor learning is ComplexityOrganization (Naylor \& Briggs, 1963), in which PAs are classified as more or less complex or organized. "Organization refers to the interrelationships between each part of the task, and complexity refers to the demand placed on an individual related to the processing of information" (Naylor \& Briggs, 1963, as cited by Hillman, 2020).

However, there is a lack of classification systems of PAs based on basic psychological properties, such as motivation. Considering that motivation is composed of multiple evolved fundamental systems that guide individuals to survival and reproduction (Kenrick, Griskevicius, Neuberg \& Schaller, 2010), categorization of PAs according to individual motives can be valuable. The Renovated Pyramid of Needs is composed by fundamental motivational systems of Immediate Physiological Needs, Self-Protection, Affiliation, Status/Esteem, Mate Acquisition, Mate Retention, and Parenting (Kenrick et al., 2010). These systems can be attained through PA.

Previous studies focused on comparing different categories of PAs according to motivational subscales (e.g., Frederick \& Ryan, 1993; Hsu \& Valentova, 2020; Molanorouzi, Koo \& Morris, 2015). Sport participants reported greater intrinsic motives, whereas bodily related motives were more frequent among exercise participants (Frederick \& Ryan, 1993; Hsu \& Valentova, 2020). However, the previous categorizations were not data driven, which can lead to stereotyping or grouping of activities that, in fact, do not create homogenous groups.

Here we aimed to analyse PAs with and without previous grouping, to explore which PAs would be more similar according to different motivational subscales. The present research is exploratory, and we hypothesized that some PAs may present a certain difference in grouping compared to others, even having the same classification according to previous authors classification systems. For instance, walking and running are considered as organized exercises, but differ considerably depending on the criterion used, such as intensity or energy expenditure. As well, rowing and swimming are considered organized exercises, but differ considerably on the number of participants, one is usually a group activity and the other an individual activity. Thus, they may show different scores in some motives, which may support a different categorization of them.

\section{METHODS}




\section{Participants}

Participants were recruited through convenience samples via social networks (Facebook and WhatsApp) and mailing lists at one of the most well-ranked universities Brazilian public university. We recruited 1,421 participants who stated themselves as physically active (mean age $=26.83, \mathrm{SD}=10.49), 564$ men $($ mean age $=28.05, \mathrm{SD}=$ 11.40 ) and 856 women (mean age $=25.98, \mathrm{SD}=9.70$ ).

\section{Instruments}

The participants (total $N=1294$ ) indicated the activity they most frequently practiced. Table 2.1 shows all activities included into this study, their respective number of participants and classification based on previous studies. Since the previous studies have not classified all PAs included in our dataset or did not have precise operational definitions, the first and second authors categorized together each PA considering the definitions and similar PAs from the previous studies. Table 2.2 shows the total of PAs splitted into each classification system. This study is part of a broader project, and here we report the instruments analyzed for this specific study.

The participants answered the Motivation for Physical Activity Measure Revised (Ryan et al., 1997) that measures, in 30 items answered on 7- point likert scales, five motivational subscales related to PA: intrinsic (Competence, Interest/Enjoyment) and extrinsic (Appearance, Fitness/Health, Social). The internal consistency measured by Cronbach's alphas were: Interest/Enjoyment $(\alpha=.92)$; Competence $(\alpha=.90)$; Appearance $(\alpha=.89)$; Fitness/Health $(\alpha=.80)$ and Social $(\alpha=.85)$. 
Table 2.1. Distribution of groupings of physical activities

\begin{tabular}{|c|c|c|c|c|c|}
\hline $\begin{array}{l}\text { Total } \\
\mathrm{N}\end{array}$ & $\%$ & $\begin{array}{l}\text { Level of PA } \\
\text { Organization }\end{array}$ & $\begin{array}{l}\text { Number of } \\
\text { participants }\end{array}$ & $\begin{array}{l}\text { Physiological } \\
\text { Demand }^{2}\end{array}$ & $\begin{array}{l}\text { Intensity of energy } \\
\text { expenditure }^{3}\end{array}$ \\
\hline
\end{tabular}

1

\begin{tabular}{llllllll}
\hline Strength & 344 & 26.6 & Complexity & Individual & Strength & Moderate & Rhythmicity \\
Running & 151 & 11.7 & Organization & Individual & Cardiorespiratory & Vigorous & Rhythmicity \\
Walking & 88 & 6.8 & Organization & Individual & Cardiorespiratory & Light & Rhythmicity \\
Swimming & 69 & 5.3 & Complexity & Individual & Cardiorespiratory & Vigorous & Water Practices \\
Pilates & 63 & 4.9 & Complexity & Individual & Hybrid & Moderate & Rhythmicity \\
Futsal & 45 & 3.5 & Complexity & Team & Hybrid & Vigorous & Combativeness \\
Soccer & 40 & 3.1 & Complexity & Team & Hybrid & Vigorous & Combativeness \\
Volleyball & 47 & 3.6 & Complexity & Team & Hybrid & Vigorous & Combativeness \\
Handball & 33 & 2.6 & Complexity & Team & Hybrid & Vigorous & Combativeness \\
Basketball & 32 & 2.5 & Complexity & Team & Hybrid & Vigorous & Combativeness \\
Dances & 31 & 2.4 & Complexity & Both & Cardiorespiratory & Vigorous & Rhythmicity \\
Tennis & 29 & 2.2 & Complexity & Both & Hybrid & Vigorous & Combativeness \\
Cycling & 27 & 2.1 & Organization & Individual & Cardiorespiratory & Vigorous & Rhythmicity \\
Athletics & 26 & 2.0 & Complexity & Individual & Hybrid & Vigorous & Combativeness \\
Rugby & 19 & 1.5 & Complexity & Team & Hybrid & Vigorous & Combativeness \\
Yoga & 25 & 1.9 & Complexity & Individual & Hybrid & Light & Rhythmicity \\
Ballet & 24 & 1.9 & Complexity & Individual & Cardiorespiratory & Moderate & Rhythmicity \\
Bycicling/Bike & 21 & 1.6 & Organization & Individual & Cardiorespiratory & Moderate & Rhythmicity \\
Kung Fu & 19 & 1.5 & Complexity & Individual & Hybrid & Vigorous & Combativeness
\end{tabular}




\begin{tabular}{llllllll}
\hline Crossfit & 17 & 1.3 & Complexity & Individual & Strength & Vigorous & Rhythmicity \\
Functional Training & 16 & 1.2 & Complexity & Individual & Strength & Vigorous & Rhythmicity \\
Karate & 16 & 1.2 & Complexity & Individual & Hybrid & Vigorous & Combativeness \\
Gymnastics & 14 & 1.1 & Complexity & Individual & Hybrid & Moderate & Rhythmicity \\
MuayThay & 13 & 1.0 & Complexity & Individual & Hybrid & Vigorous & Combativeness \\
Table Tennis/Badminton & 12 & .9 & Complexity & Both & Hybrid & Moderate & Combativeness \\
Pole Dance & 12 & .9 & Complexity & Individual & Cardiorespiratory & Moderate & Rhythmicity \\
Boat (Rowing/Canoeing) & 11 & .9 & Organization & Both & Hybrid & Vigorous & Water Practices \\
Aerobics & 10 & .8 & Organization & Individual & Cardiorespiratory & Vigorous & Rhythmicity \\
Boxing & 9 & .7 & Complexity & Individual & Hybrid & Vigorous & Combativeness \\
Jiu-Jitsu & 8 & .6 & Complexity & Individual & Hybrid & Vigorous & Combativeness \\
Judo & 8 & .6 & Complexity & Individual & Hybrid & Vigorous & Combativeness \\
Hydrogymnastics & 8 & .6 & Complexity & Individual & Cardiorespiratory & Moderate & Water Practices \\
Exercises & 7 & .5 & Complexity & Individual & Hybrid & Moderate & Rhythmicity \\
Total (sample) & $1, .294$ & 100.0 & & & & &
\end{tabular}

1- Based on Naylor \& Briggs (1963); 2- Based on Caspersen, Powell \& Christensen, 1985); 3- Based on Ainsworth et al. (2011); 4- Based on Cardoso et al. (2020). 
Table 2.2. Frequencies of groupings of physical activities

\begin{tabular}{|c|c|c|}
\hline & $\mathrm{N}$ & $\%$ \\
\hline Level & PA & 100.0 \\
\hline \multicolumn{3}{|l|}{ Organization $^{1}$} \\
\hline Complexity & 898 & 69.7 \\
\hline Organization & 398 & 30.3 \\
\hline \multicolumn{3}{|c|}{ Number of Participants } \\
\hline Individual & 988 & 76.4 \\
\hline Team & 216 & 16.7 \\
\hline Both & 83 & 6.9 \\
\hline \multicolumn{3}{|c|}{ Physiological Demand $^{2}$} \\
\hline Strength & 375 & 29.0 \\
\hline Cardiorespiratory & 438 & 33.8 \\
\hline Hybrid & 474 & 37.2 \\
\hline \multicolumn{3}{|c|}{$\begin{array}{l}\text { Intensity of energy } \\
\text { expenditure }^{3}\end{array}$} \\
\hline Light & 112 & 8.7 \\
\hline Moderate & 501 & 38.7 \\
\hline Vigorous & 674 & 52,6 \\
\hline \multicolumn{3}{|l|}{ Motor orientation ${ }^{4}$} \\
\hline Combativeness & 356 & 27.5 \\
\hline Rhythmicity & 843 & 65.1 \\
\hline Water Practices & 88 & 7.4 \\
\hline
\end{tabular}

Total (sample) $\quad 1,294 \quad 100.0$

1- Based on Naylor \& Briggs (1963); 2- Based on Caspersen, Powell \& Christensen, 1985); 3- Based on Ainsworth et al. (2011); 4- Based on Cardoso et al. (2020).

\section{Procedure}

Data were collected online using Qualtrics software (Qualtrics, Provo, UT). No reward was provided for participating in the study. The project was approved by the IRB of the Institute of Psychology, University of São Paulo (number 1.506.899, approved on April 19th, 2016).

\section{Statistical Analyses}

Analyses were conducted with Statistical Package for Social Sciences (SPSS) version 21.0. 
Regarding the analyses of previous classifications, to test for effect of each classification of PA, we performed separated Multivariate General Linear Models (GLM) with type of motivation as dependent variable, while types of PA as fixed factors. Tests of Between-Subject Effects were further checked to estimate the main effects, and Estimated Marginal Means with Bonferroni correction were consulted as post-hoc tests. We also performed correspondence analysis to graphically illustrate the PAs grouping according to each category.

Regarding the analysis without previously grouping PAs, we performed KruskalWallis analyses of variances with all PAs categories as fixed factors, and each motivational subscale as dependent variable. Significance was established at 0.05 .

\section{RESULTS}

\section{Effect of Complexity-Organization on motives for physical activity}

GLM showed significant effects for Complexity/Organization [Wilks' $\Lambda=.947$, $F(1,2)=14.22, p<.001]$.

As shown in Table 2.3, PA higher in Complexity over-scored the PA higher in Organization in Interest/Enjoyment, Competence and Social motives, while Organization PAs had higher scores than Complexity in Fitness/Health motivation. No significant differences were found in Appearance motives.

Table 2.3. Differences between mean scores $( \pm S D)$ of motivational dimensions divided into Complexity and Organization

\begin{tabular}{lllll}
\hline & $\begin{array}{l}\text { Complexity } \\
\text { Mean (SD) }\end{array}$ & $\begin{array}{l}\text { Organization } \\
\text { Mean (SD) }\end{array}$ & F statistics & Eta squared \\
\hline Interest/Enjoyment & $5.52(1.42)$ & $5.19(1.39)$ & $14.54^{\star *}$ & .011 \\
Competence & $4.97(1.53)$ & $4.44(1.66)$ & $30.74^{\star *}$ & .023 \\
Appearance & $4.82(1.67)$ & $4.68(1.48)$ & 2.17 & .002 \\
Fitness/Health & $5.77(1.16)$ & $5.93(1.05)$ & $5.67^{\star}$ & .004 \\
Social motivation & $2.90(1.59)$ & $2.43(1.44)$ & $25.51^{\star *}$ & .019 \\
\hline${ }^{*} \mathrm{p}<.005 ;{ }^{*} \mathrm{p}<.001$ & & & &
\end{tabular}

Effect of Number of Participants in each activity on motivation for physical activity 
GLM showed significant effects for Number of Participants [Wilks' $\Lambda=.674, F$ $(2,3)=55.83, p<.001$.$] .$

As shown in Table 2.4, Individual PAs significantly differed from Team PAs in all motivational subscales, with the intermediate category (Both) showing lower scores compared to Team only for Social motives. Individual PAs had the highest scores on Fitness/Health and Appearance motives, while Team and Both scored the highest on Interest/Enjoyment and Competence motives.

Table 2.4. Differences between mean scores $( \pm S D)$ of motivational dimensions divided according to predominant Number of Participants

\begin{tabular}{|c|c|c|c|c|c|}
\hline & $\begin{array}{l}\text { Individual } \\
\text { Mean (SD) }\end{array}$ & $\begin{array}{l}\text { Team- } \\
\text { Mean (SD) }\end{array}$ & $\begin{array}{l}\text { Both- } \\
\text { Mean (SD) }\end{array}$ & $\begin{array}{l}\mathrm{F} \\
\text { statistics }\end{array}$ & $\begin{array}{l}\text { Eta } \\
\text { squared }\end{array}$ \\
\hline Interest/Enjoyment & $5.17(1.48)^{2}$ & $6.27(.75)^{1}$ & $6.15(.82)^{1}$ & $71.87^{\star \star}$ & .101 \\
\hline Competence & $4.65(1.64)^{2}$ & $5.40(1.21)^{1}$ & $5.14(1.42)^{1}$ & $22.70^{\star *}$ & .034 \\
\hline Appearance & $5.04(1.54)^{1}$ & $3.94(1.59)^{2}$ & $3.84(1.45)^{2}$ & $61.53^{\star *}$ & .087 \\
\hline Fitness/Health & $5.98(1.03)^{1}$ & $5.28(1.29)^{2}$ & $5.33(1.32)^{2}$ & $45.06^{* *}$ & .066 \\
\hline Social motivation & $2.36(1.38)^{3}$ & $4.25(1.32)^{1}$ & $2.76(1.56)^{2}$ & $181.44^{\star *}$ & .220 \\
\hline
\end{tabular}

Means $( \pm S D$ ) with the same uppercase numbers do not differ from each other (using Bonferroni's posthoc comparisons). ${ }^{*} \mathrm{p}<.005 ;{ }^{* *} \mathrm{p}<.001$

\section{Effect of predominant Physiological Demand on motivation for physical activity}

GLM showed significant effects for predominant Physiological Demand [Wilks' $\Lambda=.706, F(2,3)=48.75, p<.001$.].

As shown in Table 2.5, the three categories of PA differed among almost all motivational subscales, with Hybrid showing the highest scores on Interest/Enjoyment, Competence and Social motives, while Strength showed the highest scores on Fitness/Health and Appearance motives. Cardiorespiratory PAs had an intermediate position in all subscales.

Table 2.5. Differences between mean scores $( \pm S D)$ of motivational dimensions divided according to predominant Physiological Demand

\begin{tabular}{llllll}
\hline & $\begin{array}{l}\text { Strength - Mean } \\
(\mathrm{SD})\end{array}$ & $\begin{array}{l}\text { Cardiorespiratory } \\
-\end{array}$ & $\begin{array}{l}\text { Hybrid- } \\
\text { Mean (SD) }\end{array}$ & $\begin{array}{l}\text { F } \\
\text { statistics }\end{array}$ & $\begin{array}{l}\text { Eta } \\
\text { squared }\end{array}$ \\
& & & & \\
\hline Interest/Enjoyment & $4.86(1.61)^{3}$ & $5.36(1.39)^{2}$ & $5.91(1.08)^{1}$ & $62.49^{\star *}$ & .089 \\
Competence & $4.54(1.66)^{2}$ & $4.58(1.66)^{2}$ & $5.23(1.36)^{1}$ & $27.35^{\star *}$ & .041 \\
Appearance & $5.77(1.23)^{1}$ & $4.61(1.52)^{2}$ & $4.15(1.61)^{3}$ & $130.07^{\star *}$ & .168
\end{tabular}




$\begin{array}{llllll}\text { Fitness/Health } & 6.16(0.94)^{1} & 5.83(1.13)^{2} & 5.54(1.20)^{3} & 33.17^{* *} & .049 \\ \text { Social motivation } & 2.16(1.25)^{3} & 2.55(1.47)^{2} & 3.41(1.61)^{1} & 82.15^{\star *} & .113\end{array}$

Means ( $\pm S D$ ) with the same uppercase numbers do not differ from each other (using Bonferroni's posthoc comparisons). ${ }^{*} p<.005 ;{ }^{* \star} p<.001$

\section{Effect of Intensity of Energy Expenditure on motivation for physical activity}

GLM showed significant effects of type of Energy Expenditure on motives for PAs [Wilks' $\Lambda=.750, F(2,3)=39.66, p<.001$.]

As shown in Table 2.6, Vigorous PAs differed from the other types on almost all motivational subscales, having the highest scores on Interest/Enjoyment, Competence, and Social motives. Moderate PAs had the highest scores on Appearance and Fitness/Health motives, while Light PAs showed lower scores than Moderate or Vigorous in all motivational subscales.

Table 2.6. Differences between mean scores $( \pm S D)$ of motivational dimensions divided according to predominant Intensity of Energy Expenditure

\begin{tabular}{llllll}
\hline & Light - Mean & $\begin{array}{l}\text { Moderate- } \\
\text { Mean (SD) }\end{array}$ & $\begin{array}{l}\text { Vigorous- } \\
\text { Mean (SD) }\end{array}$ & $\begin{array}{l}\mathrm{F} \\
\text { statistics }\end{array}$ & $\begin{array}{l}\text { Eta } \\
\text { squared }\end{array}$ \\
\hline Interest/Enjoyment & $4.79(1.46)^{2}$ & $4.97(1.56)^{2}$ & $5.86(1.13)^{1}$ & $75.98^{\star *}$ & .106 \\
Competence & $3.70(1.69)^{3}$ & $4.54(1.64)^{2}$ & $5.18(1.40)^{1}$ & $57.96^{* *}$ & .083 \\
Appearance & $4.15(1.68)^{2}$ & $5.38(1.46)^{1}$ & $4.43(1.58)^{2}$ & $64.71^{\star *}$ & .092 \\
Fitness/Health & $5.65(1.22)^{2}$ & $5.99(1.05)^{1}$ & $5.72(1.16)^{2}$ & $9.74^{\star *}$ & .015 \\
Social motivation & $2.10(1.25)^{2}$ & $2.19(1.27)^{2}$ & $3.29(1.61)^{1}$ & $94.88^{\star *}$ & .129 \\
\hline
\end{tabular}

Means ( $\pm S D$ ) with the same uppercase numbers do not differ from each other (using Bonferroni's posthoc comparisons). ${ }^{*} \mathrm{p}<.005 ;{ }^{* *} \mathrm{p}<.001$

\section{Effect of Motor Orientation on motivation for physical activity}

GLM showed significant effects of Motor Orientation on motives for PAs [Wilks' $\Lambda=.708, F(2,3)=48.22, p<.001$.].

As shown in Table 2.7, Combativeness significantly differed from Rhythmicity on all motivational subscales, with Water Practices always showing intermediate values. Rhythmicity had the highest scores on Fitness/Health and Appearance motives, while Combativeness had the highest scores on Interest/Enjoyment and Competence motives.

Table 2.7. Differences between mean scores $( \pm S D)$ of motivational dimensions divided according to predominant Motor Orientation. 


\begin{tabular}{llllll}
\hline & $\begin{array}{l}\text { Combativeness } \\
\text { - Mean (SD) }\end{array}$ & $\begin{array}{l}\text { Rhythmicity- } \\
\text { Mean (SD) }\end{array}$ & $\begin{array}{l}\text { Water- } \\
\text { Mean (SD) }\end{array}$ & $\begin{array}{l}\text { F } \\
\text { statistics }\end{array}$ & $\begin{array}{l}\text { Eta } \\
\text { squared }\end{array}$ \\
\hline Interest/Enjoyment & $6.15(.85)^{1}$ & $5.08(1.52)^{3}$ & $5.74(1.05)^{2}$ & $83.21^{* *}$ & .115 \\
Competence & $5.42(1.22)^{1}$ & $4.52(1.66)^{3}$ & $5.02(1.45)^{1}$ & $43.73^{* *}$ & .064 \\
Appearance & $4.11(1.63)^{3}$ & $5.07(1.54)^{1}$ & $4.64(1.43)^{2}$ & $48.23^{* *}$ & .070 \\
Fitness/Health & $5.47(1.25)^{2}$ & $5.96(1.06)^{1}$ & $5.88(.94)^{1}$ & $25.16^{* *}$ & .038 \\
Social motivation & $3.86(1.48)^{1}$ & $2.26(1.32)^{3}$ & $3.09(1.56)^{2}$ & $168.75^{\star *}$ & .208 \\
\hline
\end{tabular}

Means $( \pm S D$ ) with the same uppercase numbers do not differ from each other (using Bonferroni's posthoc comparisons). ${ }^{*} \mathrm{p}<.005 ;{ }^{* *} \mathrm{p}<.001$

\section{Effects of using no categories of physical activity on subscales of motivation}

The Kruskal-Wallis test revealed a statistically significant effect of PA on Interest/Enjoyment, $X 2(32)=298.56, p<.001$. Overall, Walking was the least Interest/Enjoyment motivated PA.

The multiple comparison rank medians showed that Walking had lower scores in Interest/Enjoyment than Swimming, Karate, Kung Fu, Basketball, Rugby, Tennis, Soccer, Dances, Handball, CrossFit, Volleyball, Futsal, Ballet and Pole Dance (all p's $<.05$ ). Also, Aerobics had lower scores than Volleyball, Futsal and Ballet (all p's < .007). There were no other significant differences.

Regarding effects of physical activity on Competence motivation, the KruskalWallis test revealed statistically significant effect of PA on Competence, $X^{2}(32)=$ 194.04, $\mathrm{p}<.001$. Walking was the least competence motivated PA.

The multiple comparison rank medians showed that Walking had lower scores in Competence motivation than Swimming, Karate, Kung Fu, Jiu-Jitsu, Basketball, Rugby, Tennis, Soccer, Dances, Handball, CrossFit, Strength, Running, Athletics, Volleyball, Futsal, Ballet, Pilates and Pole Dance (all p's $<.033$ ). Also, Aerobics had lower scores than CrossFit $(p=.021)$. Bicycling/Bike had lower scores than Kung Fu, Pole Dance and CrossFit (all p's <.038).

Regarding effects of physical activity on Social motivation, the Kruskal-Wallis test revealed a statistically significant effect of $P A X^{2}(32)=375.87, p<0.001$. Aerobics and Pilates were the least socially motivated PAs.

The multiple comparison rank medians showed that Aerobics had lower scores than Soccer, Volleyball, Basketball, Futsal, Handball, Athletics and Rugby (all p's < .017). Pilates had lower scores than CrossFit, Swimming, Dances, Tennis, Table Tennis/Badminton, Soccer, Volleyball and Basketball, Futsal, Handball, Athletics and Rugby (all p's < .003). 
Regarding effects of physical activity on Fitness/Health motivation, the KruskalWallis test revealed a statistically significant effect of $P A X^{2}(32)=151.97, p<0.001$. Handball and Dances were the least Fitness/Health oriented PAs.

The multiple comparison rank medians showed Handball with lower scores than Running, Swimming, Strength, Functional Training, Jiu-Jitsu and CrossFit (all p's < .039). Dances had lower scores than Strength, Running and CrossFit (all p's < .004).

Regarding effects of physical activity on Appearance motivation, the KruskalWallis test revealed a statistically significant effect of $P A X^{2}(32)=317.40, p<0.001$. Yoga, Handball and Tennis were the least Appearance oriented PAs.

The multiple comparison rank medians showed that Handball had lower scores than Running, Strength and CrossFit (all p's < .037). Tennis had lower scores than Strength and Running (all p's < .038). Yoga had lower scores than Running, Strength and CrossFit (all p's <.025).

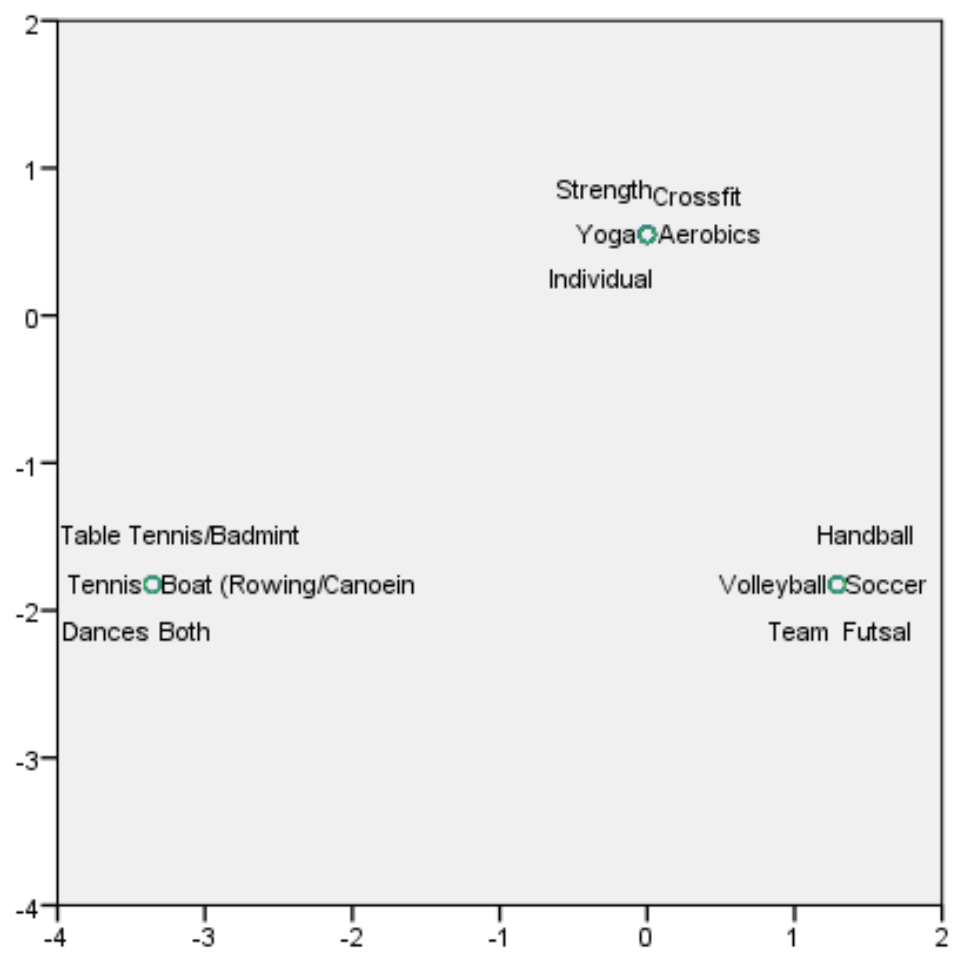

Supplementary Figure 1- Grouping of physical activities according to usual Number of Participants. 


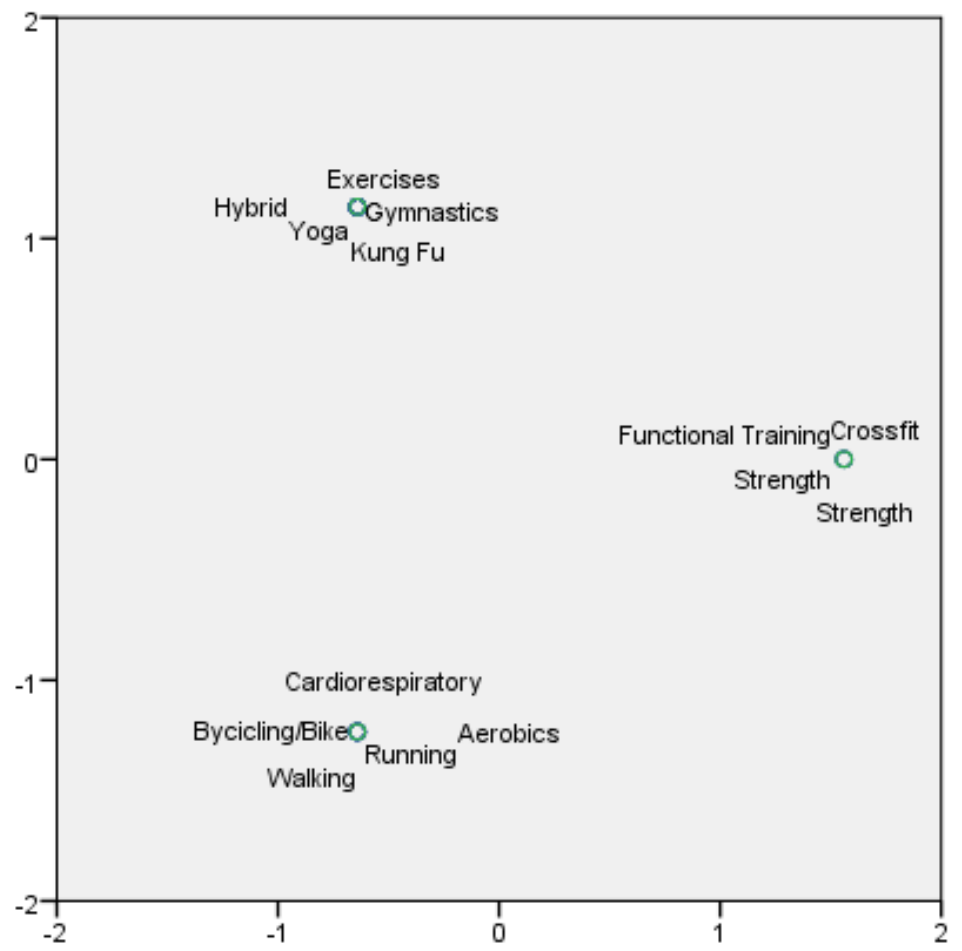

Supplementary Figure 2- Grouping of physical activities according to predominant physiological demand.

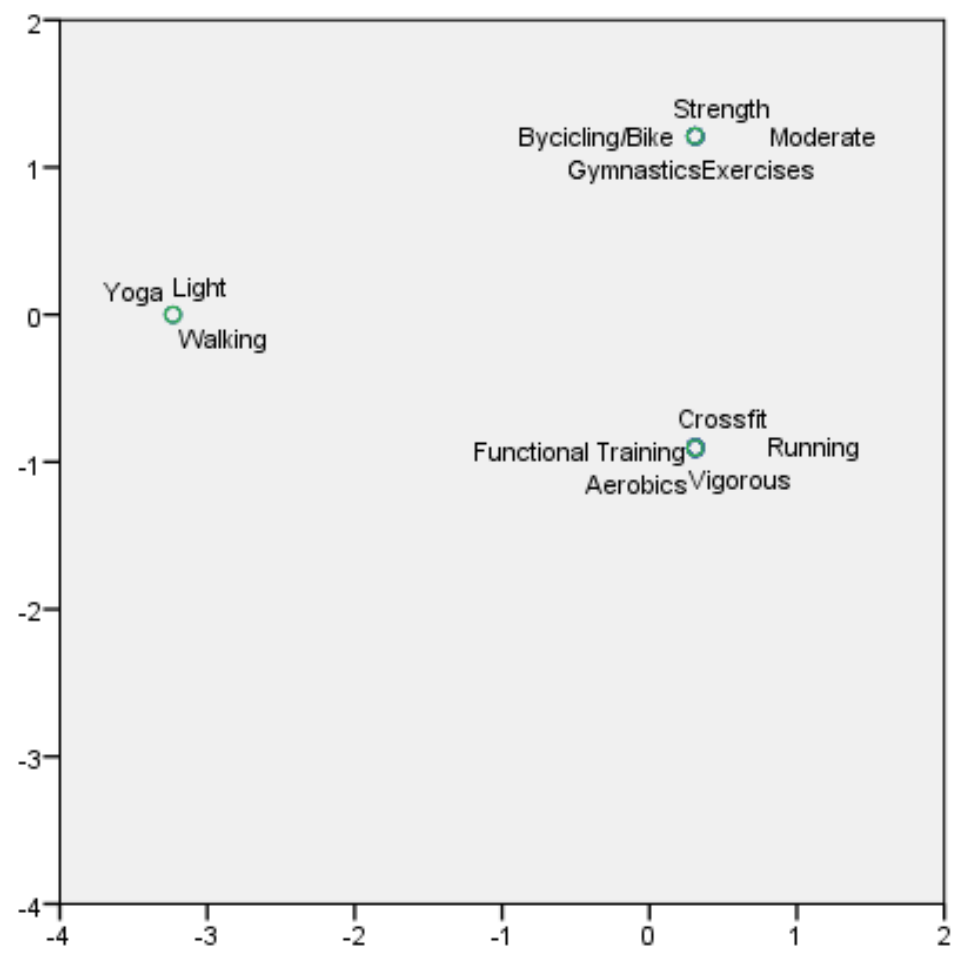

Supplementary Figure 3- Grouping of physical activities according to Intensity of Energy Expenditure. 


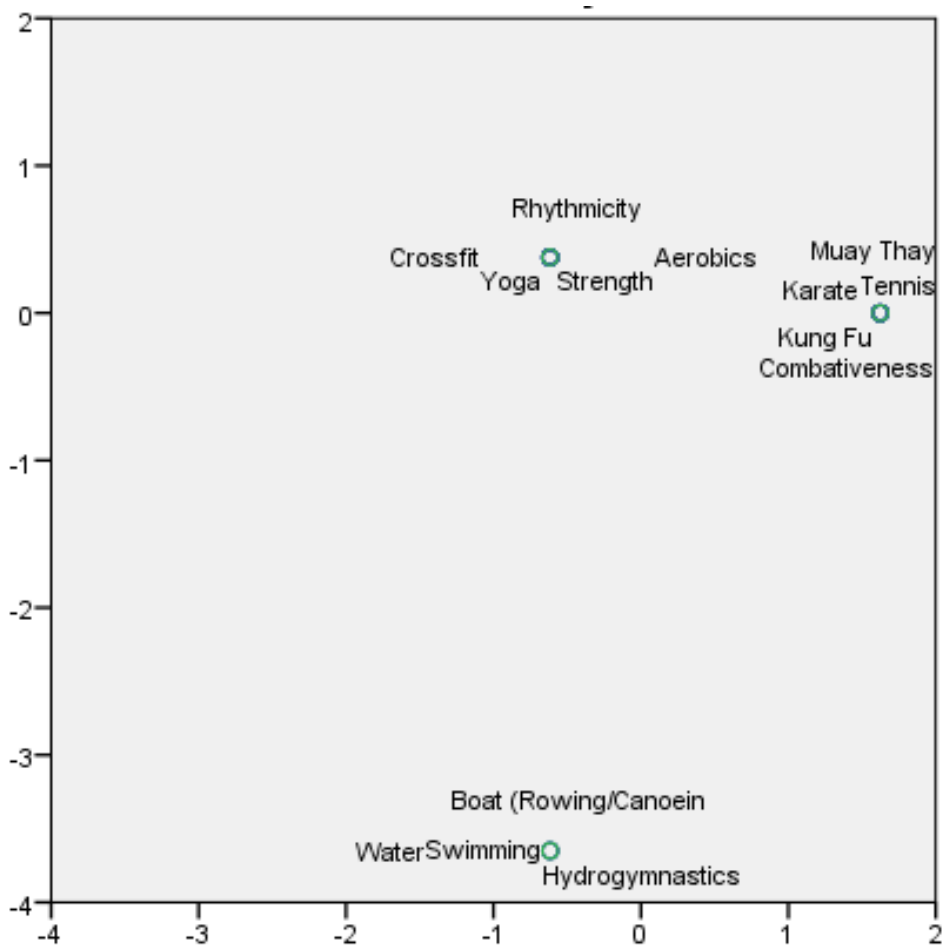

Supplementary Figure 4- Grouping of physical activities according to predominant Motor Orientation.

\section{DISCUSSION}

Here we aimed to compare physical activities according to five motivation subscales in order to verify possible similarities and differences, using previously proposed classification systems or a more data driven analysis.

Results mainly showed that different classification systems presented a similar distinction regarding extrinsic and intrinsic motives. Interest/Enjoyment, Competence and Social motives tend to be greater for PAs defined as more complex, practiced in teams, with hybrid physiological predominance, vigorous effort and with motor orientation of combativeness. On the other hand, Fitness/Health and Appearance motives tend to be greater for PAs defined as more organized, individual, with predominance of strength, moderate effort and with motor orientation of rhythmicity.

Regarding the analyses without previous grouping, Walking is less motivated by Interest/Enjoyment and Competence, compared to most sports participants. Further, Aerobics and Pilates were less socially motivated than several sports, mainly collective/team. Fitness/Health motives were lower in Dances and Handball in comparison to some exercises. Finally, Appearance motives tend to be lower in Tennis, Yoga and Handball in comparison to some exercises, such as Strength and Running. 
Walking is usually classified as a light to moderate PA (Ainsworth et al., 2011), and can be performed in varied domains with different intentions (Niven \& Markland, 2016). Here, we analyzed Walking as a leisure-time PA. Compared to several other PAs Walking was one of the least intrinsically motivating. The existing evidence is insufficient to conclude that Walking provides enough opportunities for feelings of competence or pleasure (Niven \& Markland, 2016; Morris \& Hardman, 1997).

However, the possibility of not being as enjoyable or challenging as other PAs does not erase Walking's contributions to well-being. In fact, it is known that a Walking intervention is capable of increasing exercise self-efficacy and general self-efficacy (Duranso, 2019). Walking is self-regulated, accessible, requires almost no equipment, and has minimal adverse effects (Morris \& Hardman, 1997). Thus, Walking is one of the most frequently practiced PAs, especially among starters. Further, some participants may prefer other PAs (such as Tennis) but lack opportunities for doing them. Thus, Walking emerges as a good option, especially for initiation of PA, since it is a very accessible PA, and most people are physically and economically able to do it.

Regarding social motives, we showed that Pilates was the least socially motivated PA. In general, Pilates is a frequently studied PA, and its benefits to health are well-documented (Memmedova, 2017). Despite our results, relatedness is considered an important factor for maintenance of Pilates, following competence (Lee, 2018). Possibly, although social motives constitute an important aspect regarding Pilates participation, it is not as strong as other motives, for example competence. In addition to this, people may prefer other PAs to socialize, such as team sports, whose inherent structure enables them to socially interact and thus fulfill one's universal needs for relatedness (Leary \&Baumeister, 1995; Ryan \&Deci, 2000).

Appearance motivation was the strongest for Strength and Running, which were also the most frequently chosen as primary PAs (nStrength $=344$, nRunning $=151$ ). Strength leading to muscle hypertrophy and Running leading to fat burning are obviously the most practiced PAs, and appearance is thus among the most important motives for PAs. Appearance motivation is important, since it affects everyday lives in many social contexts, including partner selection (see Cash \& Thomas, 1990). Mating is among the most important basic needs (Kenrick et al., 2010) and physical attractiveness is an important cue to attract high quality mates (Buss \& Schmidt, 2019). 
However, promotion of highly Appearance oriented PAs requires caution. For example, Murray, Griffths, Mond, Kean and Blashill (2016) reported relations among appearance orientation with anabolic androgenic steroid use, eating disorders and muscle dysphoria. In addition, it is well known that extrinsic motives - Appearance included are not as effective as intrinsic motives in promoting PA adherence (Ryan et al., 1997).

Finally, regarding Fitness/Health motives, Handball had lower scores than several other PAs. In line with this, Handball participants showed, in contrast, high levels of intrinsic and social motivation. This corroborates a previous study, in which handball players showed high levels of basic psychological needs (Alesi, GómezLópez, Borrego, Monteiro \&Granero-Gallegos, 2019), thus reflecting benefits for their mental health via fulfilment of self-determination (Ryan \&Deci, 2000). In other words, Handball and other sport participants may focus on participating for motives such as interest/enjoyment, competence and social, acquiring health benefits without explicitly seeking them.

Regarding the previous classification systems of PA, our results showing similar patterns of distributions regarding motives suggests some redundancy among them. We consider future studies with different samples may be able to increase understanding regarding similarities and differences among the classification systems, in order to propose a stronger instrument to classify PAs according to different motives, and also possibly to provide theoretical advancements.

Despite being an exploratory investigation, our study allowed us to conclude that several PAs can be clearly distinguished, and possibly grouped according to motivational subscales. For example, grouping some of them as team sports (Handball, Soccer, Basketball, Volleyball, Rugby) is justified by their similar scores in Social motivation.

Summing our findings with future studies using different scales in other samples can promote a robust possibility to increase adherence. Having a motivational compendium of PAs could help to reduce drop-out and improve personalization of interventions, using each person's personality, gender cognition, gender identity, expectations and idealized motives to find a better match for them. Also, it is desirable to monitor motivational and other psychometric changes, as is done with traditional fitness measures, such as vo2, rate of perceived exertion and heart rate.

\section{ACKNOWLEDGEMENTS}


We would like to thank the Research Grant \#2016/22964-0 and Research Grant \#2018/13937-4, São Paulo Research Foundation (Fapesp). We would also like to thank for the members of Evolution, Behavior and Sexuality Lab for all support. We would also like to thank the editors and anonymous reviewers

\section{REFERENCES}

Ainsworth BE, Haskell WL, Herrmann SD, Meckes N, Bassett Jr DR, Tudor-Locke C, Greer JL, Vezina J, Whitt- Glover MC, Leon AS. 2011 Compendium of Physical Activities: a second update of codes and MET values. Medicine and Science in Sports and Exercise, 2011;43(8):1575-1581.

Ainsworth BE, Haskell WL, Herrmann SD, Meckes N, Bassett Jr DR, Tudor-Locke C, Greer JL, Vezina J, Whitt-Glover MC, Leon AS. The Compendium of Physical Activities Tracking Guide. Healthy Lifestyles Research Center, College of Nursing \& Health Innovation, Arizona State University. Retrieved from < https://sites.google.com/site/compendiumofphysicalactivities/>. Access: 20 may, 2020.

Andrade Bastos A, Salguero A, González-Boto R, et al. (2006) Motives for participationin physical activity by Brazilian adults. Perceptual and Motor Skills 102(2): 358-67.

Apostolou M, Lambrianou R (2017) What Motivates People to Do and Watch Sports? Exploring the Effect of Sex, Age, Partner Status, and Parenthood. Evolutionary Psychological Science 3(1): 20-33.

Batia A (2007) Relationships among personality, self-determination and exercise behavior. Doctoral Dissertation, University of Florida, US.

Buss, D. M., \& Schmitt, D. P. (2019). Mate preferences and their behavioral manifestations. Annual review of psychology, 70, 77-110.

Carvalho, Y. M., Manoel, E. J. (2015). A survey of body practices and primary health care in a district of São Paulo, Brazil. Motriz: Revista de EducaçãoFísica 21(1): 75-83.

Cardoso, F. L., Medeiros, T. E., Da Silva, W. R., Ferrari, E. P., \& de Melo, G. F. (2020). A vivência de práticas físicas/motoras/esportivas de homens e mulheres para propor o construto orientação esportiva. Revista Brasileira de Educação Física e Esporte, 34(3), 395-404. 
Cash, T. F. (1990). The Psychology of Physical Appearance: Aesthetics, Attributes and Images. In: Body Images, ed. Thomas F. Cash and Thomas Pruzinsky, New York: Guilford.

Duranso, C. W. (2019). Walk for well-being: The main effects of walking on approach motivation. Motivation and Emotion, 43(1), 93-102.

Florindo AA, Guimarães VV, Cesar CLG, et al. (2009) Epidemiology of leisure, transportation, occupational, and household physical activity: prevalence and associated factors. Journal of Physical Activity and Health 6(5): 625-632.

Frederick C, Ryan RM (1993) Differences in motivation for sport and exercise and their relations with participation and mental health. Journal of Sport Behavior 16(3): 124-146.

Hsu, R. M. C. S. \& Valentova, J. V. (2020). Motivation for different physical activities: A comparison among sports, exercises and body practices. Psicologia USP.

Kenrick, D. T., Griskevicius, V., Neuberg, S. L., \& Schaller, M. (2010). Renovating the pyramid of needs: Contemporary extensions built upon ancient foundations. Perspectives on psychological science, 5(3), 292-314.

Lee, H. R. (2018). An Investigation of the Pedagogic and Motivational Climate in UK Based Pilates Classes. Masters thesis, University of Gloucestershire.

Memmedova, K. (2018). Quantitative analysis of effect of Pilates exercises on psychological variables and academic achievement using fuzzy logic. Quality \& Quantity, 52(1), 195-204.

Mingo, I., \&Montecolle, S. (2014). Subjective and objective aspects of free time: The Italian case. Journal of Happiness Studies, 15(2), 425-441.

Molanorouzi K, Khoo S, Morris T (2015) Motives for adult participation in physical activity: type of activity, age, and gender. BMC public health 15(1): 1-12.

Murray, S. B., Griffiths, S., Mond, J. M., Kean, J., \&Blashill, A. J. (2016). Anabolic steroid use and body image psychopathology in men: delineating between appearance-versus performance-driven motivations. Drug and alcohol dependence, 165, 198-202.

Naylor JC, Briggs GE (1963) Effects of task complexity and task organization on the relative efficiency of part and whole training methods. Journal of Experimental Psychology 65(3): 217. 
Niven, A.G., \& Markland, D. (2016). Using self-determination theory to understand motivation for walking: Instrument development and model testing using Bayesian structural equation modelling. Psychology of Sport and Exercise, 23, 90-100.

Ryan RM, Frederick C, Lepes D, et al. (1997) Intrinsic motivation and exercise adherence. International Journal of Sport Psychology 28(4): 335-354.

Streb, A. R., Matias, T. S., Leonel, L. D. S., Tozetto, W. R., Vieira, C. G., \& Del Duca, G. F. (2019). Association between physical inactivity in leisure, work, commuting, and household domains and nutritional status in adults in the capital cities of Brazil. Revista de Nutrição, 32.

U.S. Department of Health and Human Services. Physical Activity and Health: A Report of the Surgeon General. Atlanta, GA: U.S. Department of Health and Human Services, Centers for Disease Control and Prevention, National Center for Chronic Disease Prevention and Health Promotion, 1996. 


\section{CHAPTER THREE (DRAFT)- BIG FIVE, SELF-ESTEEM, AND SOCIOSEXUALITY AS PREDICTORS OF PARTICIPATION IN PHYSICAL ACTIVITIES}

Rafael Ming Chi Santos Hsu ${ }^{1 *}$, Anthonieta Looman Mafra1, Marco Antonio Corrêa Varella $^{1}$, Renata Pereira de Felipe ${ }^{1}$, Jaroslava Varella Valentova ${ }^{1}$

DRAFT for future submission to Personality and Individual Differences

1Evolution, Behavior and Sexuality Lab, Institute of Psychology, Department of Experimental Psychology, University of São Paulo, São Paulo, Brazil

${ }^{*}$ Corresponding Author

Correspondence:

rafa.mcsh@gmail.com

\section{ABSTRACT}

Despite its health benefits, decline of physical activity in modern societies poses an issue for public health. Among other factors, personality, self-esteem and sexuality are related to physical activities, although rarely are analysed in one study, which is the aim of this study. On a sample of 858 physically active and 778 sedentary Brazilian men and women, we found that physically active men and women reported higher selfesteem, self-rated attractiveness and health. Physically active men further reported higher sociosexuality than sedentary men, but there was no effect of personality. Physically active women showed a trend towards higher sociosexual behavior, and they scored significantly higher on extraversion and conscientiousness than sedentary women. Mostly, these differences were specific for individuals practicing long-term physical activities (Maintenance), while those practicing for less than 6 months (Action) mostly scored in between. Thus, physical activities are related to several dimensions central to individual well-being, social interactions and reproduction. 


\section{INTRODUCTION}

Despite its health benefits, decline of physical activity during ontogeny (Farooq et al., 2020) in modern societies poses an issue for public health. Besides age, many factors are associated with participation in physical activities, such as gender (van Uffelen et al., 2017), personality (Wilson \& Dishman, 2015), or motivation (Hsu \& Valentova, 2020). Two meta-analyses (Rhodes \& Smith, 2006; Wilson \& Dishman, 2015) showed that physically active individuals score lower on neuroticism and higher on conscientiousness and extraversion. Openness also tends to be positively associated with physical activities (Wilson \& Dishman, 2015). Further, extroverted individuals tend to prevail among collective sports and introverts among individual sports (Weinberg \& Gould, 2011). Similarly, team sport athletes report higher Extraversion than endurance athletes (Malinauskas et al., 2014). High-risk sportists are also higher on extraversion, as well as on sensation seeking, and impulsivity (McEwan et al., 2019).

Besides being associated with sociality and extroversion, PA improve physical and mental health (Booth et al., 2012; Warburton et al., 2006) and enhance appearance (Davis \& Arnocky, 2020), and they thus positively influence self-esteem and self-concept (Liu et al., 2015). Self-esteem is a person's evaluative judgment of the self that works as an individual sociometer (Leary \& Baumeister, 2000), thus being a complementary dimension to extraversion and other personality traits. Further, selfesteem is also importantly linked to sexual life, with higher sexual esteem indicating more satisfying sexuality and better sexual communication (Ménard \& Offman, 2009).

Physical activities can thus also be associated with sexual strategies, although research on physical and sexual activities is scarce. Swami et al. (2014) found that unrestricted sociosexuality was one of the factors that predicted greater drive for muscularity. Unrestricted sociosexuality was also positively and significantly correlated with sexual sensation seeking, sexual esteem and sexual assertiveness. Further, student athletes reported having more sexual partners than non-athletes, with differences greater among men than in women (Faurie, Pontier \& Raymond, 2004). Cross-culturally, personality, sexuality, and self-esteem are interrelated (Jonason et al, 2011, Schmitt \& Jonason, 2019), but rarely studied together in association to physical activities, which is the aim of this study. 


\section{Aims and Hypothesis of the current study}

The aim of the present study was to test if regular participants of physical activities (PAs) differ from sedentary ones in Big Five personality, sociosexuality, selfesteem, and self-reported attractiveness and health. We predicted that physically active participants would score higher on extraversion, conscientiousness, openness, self-esteem, self-rated attractiveness and health, sociosexual behavior and attitudes, and lower on neuroticism than sedentary participants.

Most previous studies did not test for possible temporal effects of physical activities. Although cross-sectional in its design, our study further analyzed possible differences between physically active participants doing PA for more than 6 months (Maintenance) and those practicing for 6 months or less (Action). We expected that participants in the Action stage would show intermediate scores between participants in the Maintenance stage and sedentary participants.

Finally, unlike most studies on physical activities conducted on the North American population, we employed a less WEIRD Brazilian population, which can bring new inter-cultural insights into studies on evolved propensities towards physical activities, personality, self-esteem and sexuality.

\section{METHODS}

\section{Participants}

Participants were recruited by snowball sampling, through mailing lists to students, professors and other employees of the University of São Paulo (Brazil), and also by divulgation to the general public through social networks (Facebook and WhatsApp). The only requirement was to be above 18 or more years old. A total of 1636 responses have been recorded. From these, 922 participants considered themselves as physically active (i.e. do practice a PA regularly).

\section{Instruments}

This study was part of a broader project aimed at relations between personality and motivations for PAs. Here we report instruments relevant only for this specific study. 
Participants completed a basic sociodemographic questionnaire, and indicated if they practiced regularly some PA. If not, they proceeded with questionnaires on personality (see below), and if yes, they were first asked to indicate the activity they most practiced and the time of practice. Based on this information, participants were classified either into Action group (practice for less than 6 months, $N=149$ ), Maintenance group (practice for at least 6 months, $N=709)$, or Sedentary $(N=778)$, see

Table 3.1.

Also, participants rated how healthy and attractive they considered themselves (each on a 1-7 scale). The participants further filled in the following questionnaires:

Table 3.1. Classification of participants according to Prochaska and DiClemente (1983) stages of behavior change.

\begin{tabular}{lcc}
\hline & Males & Females \\
\hline Action (until 6 months) & 41 & 108 \\
Maintenance (more than 6 months) & 293 & 416 \\
Sedentary & 261 & 517 \\
Total & 595 & 1041 \\
\hline
\end{tabular}

Rosenberg's Self-Esteem Scale

We used a version of the scale validated for the Brazilian population (Sbicigo, Bandeira \& Dell'Aglio, 2010), which has 10 items separated into 6 items referring to a positive self-evaluation, and 4 items referring to a negative self-evaluation. The questions are responded using 5-point scales. Cronbach Alpha's was .89.

Reduced Scale of Personality Descriptors

Participants answered the 20 -item measure of Big Five adapted and validated by Natividade and Hutz (2015) for the Brazilian population. Each personality trait, Extraversion, Neuroticism, Conscientiousness, Agreeableness and Openness, is measured by 4 items. Similarly to Natividade and Hutz (2015), Cronbach Alphas in our study were $.50(\mathrm{O}), .68(\mathrm{C}), .86(\mathrm{E}), .82(\mathrm{~A})$, and $.68(\mathrm{~N})$.

Sociosexual Orientation Inventory- Revised

SOI-r (Penke \& Asendorpf, 2008) measures individual tendency to pursue shortterm uncommitted sexual relationships with a variety of partners. Nine items of the 
questionnaire are divided into three dimensions of behavior, desire, and attitude. For the purposes of this study, we analysed dimensions of behavior and attitude.

\section{Procedure}

Data were collected online using Qualtrics software (Qualtrics, Provo, UT). All participants first read the consent form and, by clicking confirmed their anonymous participation in the study, taking, on average, $25 \mathrm{~min}$. No reward was provided for participating in the study. The project was approved by the IRB of the Institute of Psychology of the University of São Paulo (number 1.506.899, approved on April 19th, 2016).

\section{Statistical Analyses}

Analyses were conducted with Statistical Package for Social Sciences (SPSS) version 21.0 .

We performed Multivariate General Linear Model (GLM) with Big Five, selfesteem, sociossexuality and self-evaluations as dependent variables, while group of participants (sedentary, physically active in Maintenance stage, and physically active in Action stage) entered as fixed factors, while age entered as a covariate. Test of Between-Subject Effects was further checked to estimate the main effects and Estimated Marginal Means with Bonferroni correction were consulted as post-hoc tests. The model was performed separately for men and women. All effect sizes are reported in partial eta square $\left(\eta_{p}^{2}\right)$.

\section{RESULTS}

\section{Effects of group of PA on Big Five, self-esteem, sociosexuality and self- evaluations among men}

We found significant effects of the group of participants - sedentary, Action or Maintenance [Wilks' Lambda $=.858, \mathrm{~F}(3,2)=4.617, p<.001, \eta^{2}=.073$ ] on Big Five, sociosexuality, self-esteem, and the other self-evaluations.

As illustrated in Table 3.2, the Maintenance group scored higher on self-esteem (mean difference $=2.288, p<0.001$ ) and self-rated attractiveness (mean difference $=$ $.445, p<0.001)$ than the Sedentary group. Maintenance group scored higher on self- 
esteem than Action group on self-esteem (mean difference $=3.038, p=.017$ ) and selfrated attractiveness (mean difference $=.391, p=.041$ ).

Further, both groups of physically active individuals scored higher than Sedentary group on self-rated health but did not differ among each other: mean difference of Maintenance vs Sedentary $=.666(p<.001)$, mean difference of Action vs Sedentary $=.555(p=.02)$, and mean difference of Maintenance vs Action $=.111$ $(p=.532)$.

Further, the Maintenance group scored higher on sociosexual behavior than the Sedentary group (mean difference $=.399, p=.017$ ), and no other group differences were found (mean difference of Maintenance vs Action $=.224, p=.492$, and mean difference of Sedentary vs Action $=.175, p=.328$ ).

Further, the Maintenance group scored higher on sociosexual attitude than the Sedentary group (mean difference $=.519, p=.009$ ), and higher than the Action group (mean difference $=.883, p=.022$ ). No other group differences were found (mean difference of Sedentary vs Action = .364, $p=.349$ ).

Further, the Action group scored higher on Openness than the Sedentary group (mean difference $=.350, p=.024$ ), and higher than the Maintenance group (mean difference $=.345, p=.026$ ). No other group differences were found (mean difference of Sedentary vs Maintenance $=.006, p=.944)$.

Further, the Maintenance group scored higher on Agreeableness than the Sedentary group (mean difference $=.206, p=.031$ ), and no other group differences were found (mean difference of Maintenance vs Action $=.361, p=.053$, and mean difference of Sedentary vs Action $=.155, p=.409$ ).

No group differences were found in Extraversion, Neuroticism, and Conscientiousness (all p's > .097).

Table 3.2. Men: Differences among sedentary, physically active for less than 6 months (Action group), and physically active for more than 6 months (Maintenance group), and in personality and self-reports

\begin{tabular}{llll}
\hline & Action & Maintenance & Sedentary \\
\hline Self-Esteem & $36.95(8.46)^{\mathrm{b}^{* *}}$ & $40.24(7.14)^{\mathrm{a}}$ & $37.72(8.25)^{\mathrm{b}^{*}}$ \\
SOl-behavior & $2.88(2.19)^{\mathrm{ab}}$ & $3.17(2.00)^{\mathrm{a}}$ & $2.71(1.93)^{\mathrm{b}^{* *}}$ \\
SOI- attitude & $5.54(2.17)^{\mathrm{b}^{*}}$ & $6.41(2.34)^{\mathrm{a}}$ & $5.91(2.31)^{\mathrm{b}^{* *}}$
\end{tabular}




$\begin{array}{llll}\text { Extraversion } & 3.74(1.30)^{\mathrm{a}} & 4.08(1.48)^{\mathrm{a}} & 3.86(1.47)^{\mathrm{a}+} \\ \text { Neuroticism } & 3.76(.96)^{\mathrm{a}} & 3.88(.85)^{\mathrm{a}} & 3.93(.88)^{\mathrm{a}} \\ \text { Agreeableness } & 5.14(1.00)^{\mathrm{b}+} & 5.52(1.09)^{\mathrm{a}} & 5.30(1.16)^{\mathrm{b}^{*}} \\ \text { Conscientiousness } & 4.85(1.37)^{\mathrm{a}} & 5.12(1.23)^{\mathrm{a}} & 5.03(1.12)^{\mathrm{a}} \\ \text { Openness } & 5.40(.83)^{\mathrm{a}^{*}} & 5.05(.95)^{\mathrm{b}} & 5.05(.91)^{\mathrm{b}} \\ \text { Self-rated Health } & 5.44(.92)^{\mathrm{a}} & 5.56(1.02)^{\mathrm{a}} & 4.89(1.13)^{\mathrm{b}^{* *}} \\ \text { Self-rated } & 4.15(1.15)^{\mathrm{b}^{*}} & 4.54(1.05)^{\mathrm{a}} & 4.09(1.23)^{\mathrm{b}^{* *}} \\ \text { Attractiveness } & & & \end{array}$

Note. Means $( \pm S D)$ with same uppercase letters do not differ from each other (using Bonferroni's posthoc comparisons). ${ }^{* *} p<.001,{ }^{*} p<.05,{ }^{+} p<.09$

\section{Effects of group of PA on Big Five, self-esteem, sociosexuality and self- evaluations among women}

We found significant effects of the group of participants - sedentary, Action or Maintenance [Wilks' Lambda $=.866, \mathrm{~F}(3,2)=7.650, p<.001$.] on Big Five, sociosexuality, self-esteem and the other self-evaluations.

As illustrated in Table 3.3, both groups of physically active women scored higher on self-esteem than Sedentary participants but did not differ from each other: Maintenance vs Sedentary (mean difference $=2.095, p<.001$ ), Action vs Sedentary (mean difference $=2.147, p=.012$ ), Action vs Maintenance (mean difference $=.052$, $p=.953)$.

Similarly, both groups of physically active women scored higher on self-rated health than the Sedentary group, but they also differed from each other: mean difference of Maintenance vs Sedentary $=.777(p<.001)$, mean difference of Action vs Sedentary $=.422(p<.001)$, and mean difference of Maintenance vs Action $=.355$ $(p=.002)$.

Further, in self-rated attractiveness the Maintenance group scored higher than the Sedentary group (mean difference $=.415, p<.001$ ), while Action also scored higher than the Sedentary (mean difference $=.329, p=.004$ ), and no other group differences were found (mean difference of Action vs Maintenance $=.086, p=.465$ ). 
The Maintenance group scored higher on Extraversion (mean difference $=.411$, $p<.001$ ) and Conscientiousness (mean difference $=.324, p<.001$ ) than the Sedentary group. The Action group did not differ from the other groups (all p's > .113).

Further, both groups of physically active women scored higher on Agreeableness than the Sedentary group: mean difference of Maintenance vs Sedentary $=.167(p=.023)$, mean difference of Action vs Sedentary $=.291(p=.014)$, and no other group differences were found (mean difference of Action vs Maintenance $=.124, p=.305)$.

Further, no group differences were found in Neuroticism, Openness, sociosexual behavior or attitude (all p's > .152).

Table 3.3. Women: Differences among sedentary, physically active for less than 6 months (Action group), and physically active for more than 6 months (Maintenance group), and in personality and selfreports

\begin{tabular}{llll}
\hline & Action & Maintenance & Sedentary \\
\hline Self-Esteem & $38.84(6.96)^{\mathrm{a}^{*}}$ & $39.33(8.21)^{\mathrm{a}^{* *}}$ & $36.93(8.55)^{\mathrm{b}}$ \\
SOI-behavior & $2.42(1.36)^{\mathrm{a}}$ & $2.36(1.25)^{\mathrm{a}}$ & $2.24(1.34)^{\mathrm{a}}$ \\
SOI- attitude & $5.22(2.36)^{\mathrm{a}}$ & $4.96(2.37)^{\mathrm{a}}$ & $5.00(2.37)^{\mathrm{a}}$ \\
Extraversion & $4.24(1.61)^{\mathrm{ab}}$ & $4.45(1.57)^{\mathrm{a}}$ & $4.01(1.56)^{\mathrm{b}^{* *}}$ \\
Neuroticism & $4.22(.76)^{\mathrm{a}}$ & $4.25(.81)^{\mathrm{a}}$ & $4.21(.82)^{\mathrm{a}}$ \\
Agreeableness & $5.63(1.00)^{\mathrm{a}}$ & $5.55(1.17)^{\mathrm{a}}$ & $5.36(1.10)^{\mathrm{b}^{*}}$ \\
Conscientiousness & $5.14(1.17)^{\mathrm{a}, \mathrm{b}}$ & $5.38(1.04)^{\mathrm{a}}$ & $5.03(1.18)^{\mathrm{b}^{* *}}$ \\
Openness & $5.01(.88)^{\mathrm{a}}$ & $4.94(.97)^{\mathrm{a}}$ & $4.97(.95)^{\mathrm{a}}$ \\
Self-rated Health & $5.08(1.05)^{\mathrm{b}^{* *}}$ & $5.47(1.01)^{\mathrm{a}^{* * *}}$ & $4.67(1.18)^{\mathrm{c}}$ \\
Self-rated & $4.50(1.00)^{\mathrm{a}^{*}}$ & $4.58(1.05)^{\mathrm{a}^{* *}}$ & $4.17(1.14)^{\mathrm{b}}$ \\
Attractiveness & & &
\end{tabular}

Note. Means $( \pm S D$ ) with same uppercase letters do not differ from each other (using Bonferroni's posthoc comparisons). ${ }^{* *} p<.001,{ }^{*} p<.05,{ }^{+} p<.09$

\section{DISCUSSION}


We explored possible differences between physically active versus sedentary individuals in personality, self-esteem, and sociosexuality. Physically active men and women reported higher self-esteem, self-rated attractiveness and health. Physically active men further reported higher sociosexuality than sedentary men, but there were fewer effects of personality. Contrarily, physically active women only showed no effects of sociosexuallioty, but they scored significantly higher than sedentary women on variables such as extraversion and conscientiousness. Mostly, these differences were specific for individuals practicing long-term physical activities (Maintenance), while those practicing for less than 6 months (Action) mostly scored in between and did not differ from either the Maintenance or the Sedentary group.

Similar to previous studies (Liu et al., 2015), physically active individuals had higher self-esteem, and also rated themselves higher on attractiveness and health than sedentary participants. Increasing self-esteem through physical activities have an important influence on individual well-being (Alfermann \& Stoll, 2000; Legrand, 2014). In our study, both men and women who practiced physical activities shorter or longer time reported increased health than the Sedentary group, while only the Maintenance individuals reported also higher attractiveness. Possibly, individuals can perceive health improvement through physical activity more rapidly than appearance change. Interestingly, in our study specifically men in the Maintenance group differed significantly in self-esteem from the sedentary group, with the Action group being in between. In women, though, both active groups differed significantly from the Sedentary group. Thus, adherence to physical activities can affect self-judgments, and in some cases differently in men and women. Longitudinal studies observing different periods of time of physical activities might bring more conclusive results. 
In this study, we measured self-rated health and attractiveness. However, selfratings can differ from ratings by other people, especially in women (Pereira et al., 2019; Valentova et al., 2017). Thus, it would be of a high interest to analyse possible differences in other-rated attractiveness and health between physically active and sedentary individuals. Previous studies reported that change in nutrition and sun exposure leads to alteration of other-rated attractiveness (Lefevre \& Perrett, 2015). Similarly, we might speculate that physical activity might lead to differences in otherratings. Further, stronger men with faster movements produced dance that was rated as more attractive by women (McCarty, K., et al., Fink, 2013). Given the biomechanical similarity of dance and other physical activities, such as running, physical activities improve coordinated movements, cardiorespiratory functions, which can be reflected in self- and other-perceptions. Body movements and their training can thus have important consequences for social communication, including sexuality.

Physically active men scored higher on sociosexual attitudes and behavior than sedentary men. In women, we did not find a similar trend in sociosexuality. This is in line with previous studies showing that male college athletes report almost twice as many sex partners as nonathletes (Faurie et al., 2004), more muscular men (Frederick \& Haselton, 2007; Lassek \& Gaulin, 2009), and men with higher muscular strength and physical fitness report more female sex partners (Gallup et al., 2007; Honekopp et al., 2007). Also, among the hunter-gatherer society of Hadza, men with higher upper body strength had the reputation of better hunters, which led to their higher reproductive success (Apicella, 2014). Correspondingly, also women in modern Western societies prefer muscular men (Dixson et al., 2007; Frederick \& Haselton, 2007; Sterbova et al., 2018), men with a larger chest to waist ratio (Swami \& Tovee, 2005, Swami et al., 2007), and men with more upper-body strength (Fan, Dai, Liu, \& 
Wu, 2005; Garza et al., 2021; Sell, Lukasewski, \& Townsley, 2017). These results support the evolutionary hypothesis suggesting that secondary sexual characteristics might cue to genetic quality, abilities to hunt and/or protect the offspring, or they signal individual superiority for being a costly handicap. Indeed, muscularity is connected to testosterone action, which has some negative effects on immunity and longevity (Lassek \& Gaulin, 2009). Also, masculine men are preferred rather for short-term and avoided for long-term relationships, especially in conditions with domestic violence threat (Borras-Guevara et al., 2017). Importantly, these studies mostly focus on strength or muscularity in men, but not directly on level or different modalities of physical activities. For example, a long-distance runner would not exhibit exaggerated muscularity, but rather a respiratory and cardiovascular superiority, which might be beneficial for successful resource acquisition rather than intra-sexual combat. Thus, different physical activities may cue to different abilities and characteristics that might be beneficial under different conditions.

Despite the absence of the same pattern among female physically activitive and higher sociosexuality, a previous study showed elevated number of sexual partners in female athletes versus non-athletes (Liu et al., 2015). Besides studies focusing on attractiveness of female thinness (refs), there is evidence that a healthy lifestyle, including regular practice of physical activity, positively influences female sexual functioning and satisfaction (Mollaioli et al., 2020). In general, the focus on male muscularity and female thinness may also reflect relatively recent preferences of modern Western societies with abundance of resources, while in smaller populations with lower energy intakes and higher energy expenditure other somatotypes might be more preferred. For example, stronger women from a small-scale hunter-gatherer society of Hadza had higher reproductive success (Atkinson et al., 2012). Indeed, 
although males were probably more commonly hunters among ancestral huntergatherer populations, recent evidence points that females also hunted, at least among the early Americans (Haas et al., 2020). Thus, the role of physical activities, strength, endurance, and other fitness components on female attractiveness, sexuality, and reproduction should be studied more, in particular in a comparative cross-cultural perspective.

Finally, we found that personality was related to physical activities, but more strongly among women. More specifically, physically active women scored higher on extraversion, openness and conscientiousness, while there was no effect on neuroticism and agreeableness. Similarly, two meta-analyses (Rhodes \& Smith, 2006; Wilson \& Dishman, 2015) showed that physically active individuals score higher on conscientiousness, openness and extraversion. However, these studies also reported that lower neuroticism were associated with physical activities, which was not the case in our sample. This discrepancy may be given by the fact that we did not analyse association between personality and specific physical activities. It was shown, for example, that extroverted individuals prevail among collective and high-risk sports while introverts among individual and endurance sports (Malinauskas et al., 2014; McEwan et al., 2019; Weinberg \& Gould, 2011). Extraversion characterizes the individual in terms of sociability, being talkative, energetic and gregarious, and could be an indicator of positions in social hierarchies. Conscientiousness contemplates characteristics such as organization, caution, efficiency and productivity, and may thus function as a manifestation of whom to trust in important tasks (Michalski \& Schackelford, 2010). Both traits are thus important in social interactions, and may influence motivations for physical activities, especially in women. 
To sum up, we showed higher self-esteem, self-perceived attractiveness and health, and also higher sociosexuality among individuals who regularly engage in physical activities. Besides, physically active women were more extroverted and conscientious than sedentary women. Thus, physical activities are related to several dimensions crucial for individual well-being, specifically self-perception, personality, and sexuality.

\section{ACKNOWLEDGEMENTS}

We would like to thank Professor ??? for English proofreading. The study was supported by Research Grants \#2016/22964-0 and \#2018/13937-4, São Paulo Research Foundation (FAPESP). We also would like to acknowledge Cristina Landgraf Lee, Patrícia Izar and Fernando Luiz Cardoso for comments and suggestions on previous versions, and also for the members of EBSEX Lab for all support.

\section{REFERENCES}

Alfermann, D., \& Stoll, O. (2000). Effects of physical exercise on self-concept and wellbeing. International journal of sport psychology.

Apicella, C. L. (2014). Upper-body strength predicts hunting reputation and reproductive success in Hadza hunter-gatherers. Evolution and Human Behavior, 35(6), 508-518.

Atkinson, J., Pipitone, R. N., Sorokowska, A., Sorokowski, P., Mberira, M., Bartels, A., \& Gallup Jr, G. G. (2012). Voice and handgrip strength predict reproductive success in a group of indigenous African females.

Booth, F. W., Roberts, C. K., \& Laye, M. J. (2012). Lack of exercise is a major cause of chronic diseases. Comprehensive physiology, 2(2), 1143.

Borras-Guevara, M. L., Batres, C., \& Perrett, D. I. (2017). Aggressor or protector? Experiences and perceptions of violence predict preferences for masculinity. Evolution and Human Behavior, 38(4), 481-489. 
Davis, A. C., \& Arnocky, S. (2020). An evolutionary perspective on appearance enhancement behavior. Archives of Sexual Behavior, 1-35.

Dixson, B. J., Dixson, A. F., Li, B., \& Anderson, M. J. (2007). Studies of human physique and sexual attractiveness: Sexual preferences of men and women in China. American Journal of Human Biology, 19(1), 88-95.

Farooq, A., Martin, A., Janssen, X., Wilson, M. G., Gibson, A. M., Hughes, A., \& Reilly, J. J. (2020). Longitudinal changes in moderate-to-vigorous-intensity physical activity in children and adolescents: A systematic review and meta-analysis. Obesity Reviews, 21(1), e12953.

Frederick, D. A., \& Haselton, M. G. (2007). Why is muscularity sexy? Tests of the fitness indicator hypothesis. Personality and Social Psychology Bulletin, 33(8), 1167-1183.

Gallup, A. C., White, D. D., \& Gallup Jr, G. G. (2007). Handgrip strength predicts sexual behavior, body morphology, and aggression in male college students. Evolution and Human Behavior, 28(6), 423-429.

Garza, R., Pazhoohi, F., \& Byrd-Craven, J. (2021). Women's Preferences for Strong Men Under Perceived Harsh Versus Safe Ecological Conditions. Evolutionary Psychology, 19(3), 14747049211032351.

Haas, R., Watson, J., Buonasera, T., Southon, J., Chen, J. C., Noe, S., ... \& Parker, G. (2020). Female hunters of the early Americas. Science advances, 6(45), eabd0310.

Hönekopp, J., Rudolph, U., Beier, L., Liebert, A., \& Müller, C. (2007). Physical attractiveness of face and body as indicators of physical fitness in men. Evolution and Human Behavior, 28(2), 106-111.

Hsu, R. M. C. S., \& Valentova, J. V. (2020). Motivation for different physical activities: a comparison among sports, exercises and body/movement practices 1. Psicologia USP, 31.

Jonason, P. K., Teicher, E. A., \& Schmitt, D. P. (2011). The TIPI's validity confirmed: Associations with sociosexuality and self-esteem. Individual Differences Research, 9(1), 52-60.

Lassek, W. D., \& Gaulin, S. J. (2009). Costs and benefits of fat-free muscle mass in men: Relationship to mating success, dietary requirements, and native immunity. Evolution and Human Behavior, 30(5), 322-328. 
Leary, M. R., \& Baumeister, R. F. (2000). The nature and function of self-esteem: Sociometer theory. In Advances in experimental social psychology (Vol. 32, pp. 1-62). Academic Press.

Lefevre, C. E., \& Perrett, D. I. (2015). Fruit over sunbed: Carotenoid skin colouration is found more attractive than melanin colouration. Quarterly Journal of Experimental Psychology, 68(2), 284-293.

Legrand, F. D. (2014). Effects of exercise on physical self-concept, global self-esteem, and depression in women of low socioeconomic status with elevated depressive symptoms. Journal of Sport and Exercise Psychology, 36(4), 357-365.

Liu, M., Wu, L., \& Ming, Q. (2015). How does physical activity intervention improve self-esteem and self-concept in children and adolescents? Evidence from a meta-analysis. PloS one, 10(8), e0134804.

Malinauskas, R., Dumciene, A., Mamkus, G., \& Venckunas, T. (2014). Personality traits and exercise capacity in male athletes and non-athletes. Perceptual and Motor Skills, 118(1), 145-161.

McCarty, K., Hönekopp, J., Neave, N., Caplan, N., \& Fink, B. (2013). Male body movements as possible cues to physical strength: a biomechanical analysis. American Journal of Human Biology, 25(3), 307-312.

McEwan, D., Boudreau, P., Curran, T., \& Rhodes, R. E. (2019). Personality traits of high-risk sport participants: A meta-analysis. Journal of Research in Personality, 79, 83-93.

Ménard, A. D., \& Offman, A. (2009). The interrelationships between sexual selfesteem, sexual assertiveness and sexual satisfaction. Canadian Journal of Human Sexuality, 18.

Michalski, R. L., \& Shackelford, T. K. (2010). Evolutionary personality psychology: Reconciling human nature and individual differences. Personality and Individual Differences, 48(5), 509-516.

Mollaioli, D., Ciocca, G., Limoncin, E., Di Sante, S., Gravina, G. L., Carosa, E., ... \& Jannini, E. A. F. (2020). Lifestyles and sexuality in men and women: the gender perspective in sexual medicine. Reproductive Biology and Endocrinology, 18(1), $1-11$.

Pereira, K. J., da Silva, C. S. A., Havlíček, J., Kleisner, K., Varella, M. A. C., Pavlovič, O., \& Valentova, J. V. (2019). Femininity-masculinity and attractiveness- 
Associations between self-ratings, third-party ratings and objective measures. Personality and Individual Differences, 147, 166-171.

Rhodes, R. E., \& Smith, N. E. I. (2006). Personality correlates of physical activity: a review and meta-analysis. British journal of sports medicine, 40(12), 958-965.

Schmitt, D. P., \& Jonason, P. K. (2019). Self-esteem as an adaptive sociometer of mating success: Evaluating evidence of sex-specific psychological design across 10 world regions. Personality and Individual Differences, 143.

Sell, A., Lukazsweski, A. W., \& Townsley, M. (2017). Cues of upper body strength account for most of the variance in men's bodily attractiveness. Proceedings of the Royal Society B: Biological Sciences, 284(1869), 20171819.

Štěrbová, Z., Třebický, V., Havlíček, J., Tureček, P., Varella, M. A. C., \& Valentova, J. V. (2018). Father's physique influences mate preferences but not the actual choice of male somatotype in heterosexual women and homosexual men. Evolution and Human Behavior, 39(1), 130-138.

Valentova, J. V., Varella, M. A. C., Havlíček, J., \& Kleisner, K. (2017). Positive association between vocal and facial attractiveness in women but not in men: a cross-cultural study. Behavioural processes, 135, 95-100.

van Uffelen, J. G., Khan, A., \& Burton, N. W. (2017). Gender differences in physical activity motivators and context preferences: a population-based study in people in their sixties. BMC Public Health, 17(1), 1-11.

Warburton, D. E., Nicol, C. W., \& Bredin, S. S. (2006). Health benefits of physical activity: the evidence. Cmaj, 174(6), 801-809.

Wilson, K. E., \& Dishman, R. K. (2015). Personality and physical activity: A systematic review and meta-analysis. Personality and Individual Differences, 72, 230-242. 


\section{GENERAL DISCUSSION}

The present study analysed in different ways the phenomenon of motivation for physical activity (PA) practice, recruiting participants of several types of PA.

In this section, we integrate the previous chapters into a broader discussion, as well as highlight some practical recommendations in the context of physical activity promotion. We highlight the main results linked to the aims and predictions and make some theoretical observations that help to comprehend the main findings. Also, we highlight some of our main contributions to the field, and also some limitations.

\section{MOTIVATION AND PRACTICE OF PHYSICAL ACTIVITY}

Baumeister (2016) suggested that motor and motivational systems coevolved through phylogenetic history since the organisms needed to change their environments through movement.

Previously, we have presented motivation for physical activities as closely related to important adaptations, such as the increase in human brain size - (see, Bortz, 1984). We also highlighted the curious case of sedentarism, which remains high even with people are aware of PA benefits. Here we will highlight some possibilities that help explaining our results, and also suggest additional practical implications and future research.

\section{Differences in motivations according to type of activity}

Autonomy is proposed as an equivalent to an internal perceived locus of causality (deCharms, 1968, as cited by Ryan \& Deci, 2000a). In other words, autonomy can be understood as a self-perception of being directly responsible for a certain outcome or choice. We argue that supporting autonomy regarding PA promotion is crucial, similar to what Paulo Freire proposed for general education (e.g., 1996). Autonomy is also a pillar of Self-Determination Theory (Ryan \& Deci, 2000b).

Our results in Chapter One showed that Interest/Enjoyment, Competence (intrinsic motivations), and Social motives were higher for Sports, in particular Collective in comparison to Exercises. Exercisers, on the contrary, were motivated more by Appearance and Fitness/Health (extrinsic motivations). This distinction between sports and exercises was similar with studies from other countries, such as 
USA (Kilpatrick et al., 2005; Ryan et al., 1997; Frederick \& Ryan, 1993). A previous Brazilian study conducted in Aracaju/SE (Andrade Bastos et al., 2006), did not compare so many different types of activities (i.e., they recruited participants of Walking and Fitness) as us. Another study conducted in Natal/RN did compare sports and exercises, and found significant differences only in interest/enjoyment motivations (Gonçalves and Alchieri, 2010). It is also important to highlight that our study was the first to include the concept of body/movement practices as a category, and has found significant differences in motivations, which supports the idea of a relatively independent motivational profile among the different categories of PA.

Previous authors who addressed motivations for PA from the evolutionary perspective (e.g. Apostolou \& Lambrianou, 2017, Deaner et al., 2015) focused on discussing almost entirely on sex differences in sports, thus neglecting activity type differences.

Because of methodological issues, such as self-report measures, motivations for physical activities are difficult to study in our ancestors' generations and in nonhuman species. Because of that, we will try to apply the evolutionary reasoning recurring to another evolutionary and also some non-evolutionary authors who tried to explain physical activity behavior, and its links (direct or potential) to motivation. For example, our current historical moment is characterized by accelerated shifts that shake society and provoke imbalances in several aspects of life (Grandino, 2020). However, as presented earlier, current environment cannot be judged as the only factor influencing manifested behavior, since the great majority of evolution of our species has occurred in environments very different from today's environment (Carvalho, 1998), with naturally physically active lifestyle, very different from today's pattern (Caldwell, 2016). During the human species phylogeny, this shift in PA pattern (starting with the Agricultural Revolution) is relatively recent (approximately 10,000 years ago), and because this change in behavior did not have a sufficient duration to change significantly our genome (Cordain et al., 1998), it represents an important mismatch.

The classification of physical activities as sports, exercises or body/movement practices was directed to leisure-time PA, which is not an easy construct to apply when thinking evolutionarily. To discuss changes in PA levels throughout human evolution, we should investigate a broader range of PA categories, such as the categories frequently applied in epidemiological studies (e.g., Florindo et al., 2009): leisure, 
household, transportation, and occupational. However, non-leisure physical activities have a greater obligatory component, and their motivations are thus mostly extrinsic (e.g., to clean house because it is dirty, and not because it is an enjoyable activity). Leisure time, on the other hand, may have increased its relative importance during the documented history, partially because of cultural factors that emerged to promote PA in a structured and conscious way, such as hygiene, therapy, war preparation, bodymind integration, art, etc., until the Industrial Revolution, when specific modalities were created and promoted for leisure time (Nogueira \& Moreno, 2011). Regarding other PA domains (household, occupational, and displacement), it is possible that they have suffered considerable decline, at least in a substantial proportion of the population. This decline can be associated with technological advances starting with agriculture and later with Industrial Revolution. Caldwell (2016) suggests that human energy expenditure changed significantly from Industrial Revolution, since machines for food production decreased the need to waste energy for resource acquisition in a substantial proportion of the world population. Also, the author notes that over the last 10,000 years, several technologies have been created and were responsible for important shifts in levels of PA to fulfill several basic needs.

Mainly in richer and more developed populations, all of these innovations can be understood as mismatch, because since their dissemination, the mean energetic demands for individuals to attain survival and reproductive goals decreased significantly. This favored the overactivation of a human drive/predisposition to store energy for difficult times and avoid unnecessary expenditure, aiming to save energy in order to allocate in growth, maintenance, and reproduction (Caldwell, 2016). So, in the same way as food started to be consumed in amounts higher than needed for survival (e.g., in expensive restaurants, Baumeister, 2016), PA in a great part of worldwide population reduced its direct link to survival, thus assuming different and less often practiced manifestations (i.e., leisure time PA types). As with food, some types of PA became restricted to some elite populations (e.g., golf and 5-stars restaurants).

Baumeister (2016) points to the difficulty of creating a link between primary/general motivations (surely shared with other animals, such as motivation to fulfill immediate physiological needs, such as to eat, or to drink) and others more varied and complex, that do not appear to have direct associations with survival, such as to eat at an expansive restaurant. Similarly, nowadays PA, in general (except in societies 
without contact with technologies, very poor areas or destructed by war) are not directly linked to survival as in past times, since they are not needed to ensure food in the same magnitude as in ancestral times. Following this reasoning, it becomes clearer why some motivations to do PA (such as fitness/health) don't seem enough to promote adherence, while other motivations (e.g., interest/enjoyment and competence) do promote adherence. Doing PA because of health benefits probably was not a predominant preoccupation among our ancestors or in small-scale societies, since these people did not need to consciously think about benefits of something they were obliged to do for survival.

Also, Baumeister (2016) discusses the difficulty to erase some motivations, because they were linked to basic requisites to survival and reproduction during a long period of time. For example, motivation to eat at an expensive restaurant, although not adaptive in the past, may contain evolutionary important components, such as social (e.g., to show status or to attract sexual partners). So, although the current mismatch may be a weakening factor for motivations to do PA (since they are not as needed as in the past to accomplish several basic needs), an important proportion of people still do practice PA regularly. They are motivated both extrinsically and intrinsically, according to type of PA, which is in coherence with evolutionary predispositions to be physically active.

To explain why some people are regularly engaged in physical activities, it is important to remember the wide range of explanations (and their combination) derived from Tinbergen's (1963) four questions. For example, there is evidence supporting that talent and success in sports are directly linked to some genetic polymorphisms (Dias, Pereira, Negrão \& Krieger, 2007). This alone could induce an erroneous conclusion that some people may be more prone to be physically active only because of their genotype.

An important aspect is internalization throughout development, which occurs when enjoyment, satisfaction and positive affective responses are attained, since they help to find better meaning in life (Matias, 2019). In addition, twin studies indicate that PA is significantly influenced by both genetic and non-shared environmental (outside of family) factors (Aaltonen et al., 2015). Interestingly, previous authors who addressed motivations for PA from the evolutionary perspective (e.g., Apostolou \& Lambrianou, 
2017, Deaner et al., 2015) focused on discussing almost entirely on sex differences in sports, thus neglecting activity type differences.

Thus, it is necessary to highlight ontogenetic pathways in practicing PA. Based on the twin method of behavioral genetics, it is known that each twin has his/her unique environment and also a shared environment with the co-twin. Discordant pairs (i.e., pairs of twins differing in the studied characteristic) of monozygotic twins, even when exposed to similar opportunities, experience them differently, possibly generating unique neural pathways related to intrinsic and extrinsic motivations (for evidence regarding a twin pair discordant over 30 years in PA, see Aaltonen et al., 2012). Thus, although monozygotic twins share $100 \%$ of their genes, one cotwin can develop a physically active lifestyle, while the other not.

Another possibility is that even children twin already come to physical education classes with a well-established individuality, and their need for differentiation also may contribute to some differences between them. In general, both genetic and environmental factors are important in the development of physically in/active lifestyle.

Importantly, higher intrinsic motivations and adherence can be expected for types of PA that are relatively similar to ancestral PA. For example, play is present in most species, including non-human primates (Resende, Izar \& Ottoni, 2004; Behncke, 2018), and was most probably very present in our early hominid ancestors (as suggested by studies among hunter-gatherers, such as Brazilian Parakanã- see Gosso et al., 2005). Also, play is a very present component in many sports, having aspects responsible for generating enjoyment, such as repetitiveness and loss of control (Špinka, 2019). Due to play's intrinsic predominance, it makes sense why sports are more related to intrinsic motives than exercises.

In ancestral times, exercises were rather practiced in extreme situations, frequently obligatory, such as need to run away from predators, as would be expected according to the self-protection stage of the pyramid of needs (Kenrick et al., 2010). Regarding the fact that body/movement practices also surpassed exercises in social motivation (Chapter One), an important point is that several body/movement practices (e.g., dances) were an integral part of social events, such as ancestral rituals, which were (and continue to be) central for the social cohesion of the community (e.g., Fortes, 1936). 
However, although exercises were shown to have more extrinsic motives, and are less linked to adherence (Frederick \& Ryan, 1993; Ryan et al., 1997), a great proportion of people adhere to PA and increases their well-being and self-esteem through them. The issue does not reside in the one specific PA or type of PA, but in the underlying individual motives and attitudes towards them (Matias, 2019). For example, several important and more enjoyable, but lighter (and thus with less fitness results) PA can be alternated with/merged with more vigorous exercises (such as running), aiming to have the best combination of intrinsic and extrinsic motives. Thus, a good way of promoting exercises may be as a part of a comprehensive health program, together with one sport or body/movement practice.

Regarding social motives, an important reason for doing PA is meeting new people, which are among the main motivators of elite athletes to leave their hometown (Sanches \& Rubio, 2009). Meeting new people may also be an important aspect regarding some body/movement practices, such as dances (Vergeer, 2018; Maraz et al., 2015), also in non-heterosexual samples (Harman \& Wong, 2020). Affiliation and belongingness are among the most important motives in the pyramid of needs (Kenrick et al., 2010). The potential of some exercises to retain participants may be associated with social motives. For example, it is very common to form groups to practice exercises, such as running, bicycling, functional training, calisthenics, etc. The professional can also help by fostering the sense of belonging and group cohesion in the participants (Matias, 2019).

It is worth to note that in our questionnaire the instruction was to state the most practiced PA, as in Frederick and Ryan (1993), and not the most liked or preferred PA. Accordingly, Keer (1997) emphasizes possible barriers interposed between preference and actual participation, such as social rules, interpersonal relationships, demographic and climatic factors, and also socioeconomic factors. This strengthens the adopted procedure by us, which avoids unrealistic approaches, such as to measure motivations for Golf of an individual who practices this sport only one time per year, but would report this because it is his/her most favorite PA. However, we can't neglect the evolutionary importance of desired PA, so future studies focusing on this subject are highly welcome.

\section{Differences between male and female in motivation and practice of PA}


Complementing the discussion in Chapter 1, we found greater interest/enjoyment motives in females (in accordance with a recent publication, Larsen et al., 2021), but no differences in appearance or social motives. Also, we supported previous research related to greater prevalence of males in self-reported PA as a leisure time activity (e g., Salles-Costa et al., 2003, Costa et al., 2012, Malta et al., 2006). However, females reported more body/movement practices than men as the most frequent PA, whereas males were more prevalent in sports, also in accordance with previous research (e.g., Bélanger et al., 2015).

Although Apostolou (2015) found strong results confirming his predictions regarding sex differences in motivation for PA (e.g., greater appearance motives for females), he pointed out that due to several benefits of PA, it is plausible that both sexes value and attempt to involve in PA practice. Thus, despite possible differences in motives and functions, PA practice is valuable for all individuals.

The most important challenge seems to be how to find ways to promote a better fit for each individual's or group's peculiarities. Despite this, virtually all research on motivation for PA was directed to leisure time activities, and studies focusing on other domains would be welcome, since the prevalence clearly differs between the sexes in relation to specific PA domains. For example, although in general being less physically active, females are more active than males in the domain of household activities (Costa et al., 2012) and childcare, which is coherent with human ethological reports related to Hunter and gatherer societies' routines (see, for example, Wood \& Eagly, 2002, for evidence that women focused more on gathering and later also agricultural activities, while men engaged more in hunting activities).

These differences in prevalence of self-reported practice of PA are linked to modern sports practice and spectatorship, which in our sample were more practiced by men, thus supporting hypotheses such as "allying with coalitions" and "spectator lek", see Introduction (Apostolou \& Lambrianou, 2017, Deaner et al., 2015). More males than females practiced sports in our sample- in individual sports, there was a higher number of males, even the total sample being almost $2 / 3$ of females.

Regarding motivational aspects, predictions relating Allying with Coalitions and Spectator Lek hypotheses to sex differences suggest that warfare generally imposed greater costs, but also greater benefits to men than to women (Gat, 2006, Smith, 2007, 
as cited in Deaner, Balish \& Lombardo, 2015). However, although women reported practicing less sports than men, in our sample the social motives regarding PA did not differ between men and women, as would be expected according to the Allying with Coalitions hypothesis. A possible explanation may be related with Tend-and-Befriend effect, which is presented as a typical female response to seek protection from danger, which includes nurturing and investing in social networks (Taylor et al., 2000). According to the Tend-and-Befriend effect, women are socializing among themselves as well as men (Taylor et al., 2000), and this tendency might be recently increasing in the sociocultural context where the study was conducted.

In addition, among group living organisms, the group is an important aspect increasing survival and reproduction, thus leading toward a predominant drive to foster connections with others, instead of being in social isolation (Leary, 2001; Cacioppo et al., 2011). Thus, in many cases, formation and/or maintenance of socializing groups can increase commitment, maintenance, and enjoyment of the PA. Similarly, practicing PA in a social group may work as a team-building increasing cooperation among the individuals.

We further tested the hypothesis of no sex difference in competence motivation. Regarding development of skills hypothesis (i.e., that PA can be done as preparation or training for future activities and contexts, Deaner et al., 2015, Apostolou \& Lambrianou, 2017), competence motivation subscale in our research is an equivalent measure of self-reported development of skills, and in support of this hypothesis, we did not find any sex differences. Such result is not surprising, since a better trained individual is more prone to find better results regarding his/her life challenges, independently of being more directed to sports, exercises, or body/movement practices. According to Kenrick et al. (2010), mastery motives contribute to improve self-esteem, self-confidence and prestige, thus being a way to increase status. If selfefficacy is attained with PA practice, there will also be increase in beliefs and attitudes towards a more active lifestyle (Matias, 2019).

Further, we tested the hypothesis that PA can be performed as a signaling system with a function similar to courtship rituals of other animals, i.e., a courtship display hypothesis (De Block \& Dewitte, 2009) for PA, our results support a counterpoint to Deaner (2015) and Apostolou \& Lambrianou (2017) general predictions (i.e., less female motives for participating in all sports) when taking into account women 
participation and motivation. This is supported by female's greater involvement in more artistic and ornamental PA, which can also be equivalent as courtship display (i.e., competitive) contexts, a fact that should not be overlooked. In general, females are more prone than men to artisticality (Varella, Valentova \& Fernandez, 2015). In our study, a great proportion of more artistic activities were classified as body/movement practices, a category far more represented by women.

In our study, the noncompetitive PA (exercises and body/movement practices) can be viewed as having a similar courtship display function as sports, although probably more indirect. For example, some dances are performed at festivals with prizes and winners, which seems to fit this hypothesis. Even exercises such as bodybuilding, although performed generally in closed environments (but also in parks, beaches etc.), are activities that hold great potential to modify appearance, and they can be considered as preparation to the courtship rituals, since they can be of some help in impression formation.

Similarly, dating apps, such as Tinder and Happn, place a very high emphasis on appearance (Cunha, 2018), which can be better valued with long-term practice of different PA, because of their potential to modify appearance, thus impacting intrasexual competition and mate attraction. The absence of differences between men and women in appearance motives for PA in our study may reflect high pressures on appearance for both sexes, especially nowadays when life is governed by social media and first impressions.

The above outlined discussion can also be related to the hypothesis of socialization. Despite in some cultures women pay greater attention to appearance), it is worth to note that men also receive appearance pressures, because humans have, at least in comparison to other apes, lower sexual dimorphism and higher paternal care (Hooper \& Miller, 2008, Varella, Valentova \& Fernandez, 2015).

A large research in 50 societies found overall more male than female participation in sports, with sex differences greater in patriarchal than nonpatriarchal societies (Deaner \& Smith, 2013). Further, the lack of sex differences regarding motivations in our sample can be given by a lower gender inequality among our participants (mainly students of the University of São Paulo) than in the rest of Brazilian society, since the Brazilian public university environment has recently been hosting several gender equalizing/empowering campaigns and policies. Possibly, lower adherence to 
traditional gender roles in our sample can explain lack of sex differences. Also, our data might have been affected by the Brazilian political scenario possible impact from the political scenario when our data was collected (in 2016). In accordance, a recent study with similar design has found greater appearance motives in Norwegian men (Larsen et al., 2021).

These recent results can represent a mismatch in comparison to the prevalent scenario in human (and also many other mammals and primates) evolutionary history, which was strongly patriarchal (Smuts, 1995). Because of this, similar values attributed to appearance and also a more similar ornamentation through PA in both sexes could be expected in modern humans, and in particular among a more self-reflected, equalitarian and open-minded university sample. Despite our results, misogyny and other forms of prejudice are still structural in Brazil, and affect several fields, including PA practice (Schultz, 2021).

Future studies can improve analysis of contextual moment by collecting data in atypical situations, including their impact in each sex. For example, the COVID-19 pandemic, which in some places was accompanied with several obligatory restrictions, such as lockdown. Even with technological advances, confinement and isolation restricted people's options for doing PA (Castañeda-Babarro, Arbillaga-Etxarri, Gutiérrez-Santamaría \& Coca, 2020). Some individuals had to stop doing their regular PA, while others kept practicing in hidden facilities. Others, instead, used the opportunity to start or temporarily change their habitual PA for others available at internet (such as YouTube and Instagram).

A study focusing on motivational aspects for doing PA in this specific period and comparing with previous studies offers important insights, because of the considerable routine shift. For example, during COVID-19 pandemia, most workers and students stayed more time than before at home. Although several kept working and/or studying online, for a great part there was an increase in free time (Purwanto et al., 2020), because individuals did not waste time in car or public transport, and also because of restricted leisure opportunities, such as going to parties, parks, or cinemas.

Besides pandemics or political/economic crisis, the current society can be considered as sick because, among other factors, there is a poor connection of human beings with the nature, since our routines are influenced by values such as productivism (Resende, 2018), especially the impacts of excessive competitiveness. 
Since lack of time is considered one of the main barriers to do PA, one study exploring motives for PA practice during abnormal circumstances would be interesting: could boredom from repetitive routine plus increase in free time be a possible motive for increasing or maintaining PA levels? I believe such type of study could give important practical applications, such as thinking about a policy in which work routines were reduced (without lowering in payment), more people could be employed, and free time for PA to those already working would increase. Despite initially resulting in greater costs to employees, the health benefits would compensate this throughout time, since costs with diseases treatment would be lower, as recurrent problems such as disease-related retirement or medical licenses. Also, better health probably would reflect in better productivity, thus compensating the cons of reducing work journey with the same income. Having more free time would increase people's chances to practice $\mathrm{PA}$, thus contributing to fullness, since we live through our body, sensations, explorations and perceptions, that are our channel of communication with the world (Resende, 2018).

Another important discussion regards the limitation accounted by sex differences. It can be thought as only one layer in a universe of possible variables regarding human sexuality. We did not ask about gender, and such intrasexual variations have important influences regarding PA behavior (e.g., see Cardoso \& Saccomori, 2012). In our study, motivational subscales in which we did not find sex differences could have been different when taking into account variables such as cognitive gender or sexual orientation.

We collected, but not yet analysed data regarding sexual orientation. Another one, gender identity, we did not collect in our questionnaires. For example, Cardoso and Sacomori (2012) compared physically active and sedentary, taking into account sexual orientation and self-rated masculinity-femininity. They identified an association between gender identity and PA orientation, with more masculine women preferring sport (Cardoso \& Sacomori, 2012).

\section{CLASSIFICATION OF PHYSICAL ACTIVITIES}

Having opportunities to choose favors autonomy (Reeve, 2018). We showed that motives are different according to PA type or classification system employed. In Chapter One, we showed that adding a new category labeled Body/Movement 
practices represented a promising possibility, since it showed important differences from Exercises or Sports, which have well established differences among themselves. In Chapter Two, we showed that different classification criteria (such as Energy Expenditure or Motor Orientation) tend to converge when doing analyses according to different subscales of motives for doing PA (such as Interest/Enjoyment or Appearance). Also, some PA (such as Walking) consistently differed from most others according to the motivational subscale analysed.

Our results regarding PA type similarities and differences are important because if people have a big range of possible choices, there is a greater chance for them to find some PA that matches their initial aspirations. And also, in the future, they can experiment new PA which can fill some important blanks in their life (C.L. Lee, personal communication, 2018). For example, an amateur thin tennis player may not like strength training, but can start practicing it and internalize its benefits to performance, health and appearance, thus reserving some space in their routine for this originally non-preferred activity.

The main contribution of our first chapter was the classification of PA into Sports, Exercises, and Body/Movement Practices, emphasizing some important questions that have been mostly neglected in previous scientific research. For example, the Brazilian Federal Government adopted in its National Policy of Health Promotion (2014) the term "Body Practices" as a synonym of the broad concept of "Physical Activity". However, as stated in Chapter One, motivations clearly differ according to type of PA, and, in this sense, it is very important to highlight Body/Movement Practice as a specific type of PA, because of its high levels of intrinsic motivation (which are more related to adherence than extrinsic motives predominant in Exercises, as shown by Ryan et al., 1997). Thus, not considering distinctions of Body Practice in comparison to a broader term like PA can lead to an underestimation of motivational peculiarities according to different categories of PA.

In the same line, Carvalho (2006) has initially proposed the use of label "body practices" as representing a new understanding aimed to improve the health-related public policies, instead of a mere re-labeling of already existing terms. In line, according to C.L. Lee (personal communication, 2018), the concept of body/movement practices highlights important aspects, such as an emphasis on individuality and alternatives to more extenuating/too rigorous exercises. 
The classification proposed in Chapter One into four types of PA (Individual Sport, Collective Sport, Exercise, Body Practice) although far from perfect, contributes to a more detailed discussion of PA types and highlights some important issues. For example, a terminological consensus and the use of more operational definitions, at least within the academic field, probably would facilitate practical implications and also communication with other fields. The current terminological segregation between disciplines (epidemiology using the term "physical activity", Brazilian collective health with "body practices", physiology using "exercise", and training mainly focusing on "sport") does not contribute to advancing the knowledge, and it makes the communication difficult.

Further, using several terms without a clear delimitation favors dissemination of misunderstandings, such as the common-sense confusion of sports with physical activity or games. Terminological confusions are present even in the public policy, such as the denomination "Ministry/Secretary of Sports", which is responsible for promotion of all types of PA, not only sports. Another risk of having confusions regarding theoretical frameworks is the formulation of inadequate predictions and poor experimental designs (Bovet, 2020).

The field of physical education/sports science needs to establish agreements able to provide a better conceptual understanding (Gonzalez \& Fensterseifer, 2014). One of the present work's contributions is a greater philosophical discussion about Physical Education's study areas, and a greater clarification about its own subjects. Both contributions can also be important tools to promote a greater interdisciplinary dialogue with other professions, which is crucial to better apply health promotion strategies. It is fundamental that other professionals are aware of relations between motives and PA, to avoid precipitated and/or mistaken counselling (e.g., to recommend exercises or body practices to a person whose main motivations for practice are linked to sociability).

Our proposed classification system (sports, exercises, body/movement practices) contributed to shed light on more subtle division of PA. Still, a more detailed approach could have been adopted, since our classification probably contains some exceptions. To address that, we did another analysis, more data-driven, presented in Chapter 2. Although exploratory, we evaluate the two complementary chapters as 
important steps to propose a scientific discussion toward new classification systems that might be able to support health promotion.

In addition to the already presented limitations, a more qualitative possibility could have an even more comprehensive approach, before applying the battery of questionnaires. For example, Barreira (2018), after a phenomenological reduction, presented subcategories specifically for martial arts: a) Fight, b) Duel, c) Quarrel, and d) Play. Our predominantly quantitative data made it difficult to proceed with such expansion in meanings. Open questions have a great potential, since through them the participant can explain details about their difficulties and personal barriers that can be addressed through personalization. For example, many people perceive gym's environment as hostile, but most PA professionals do not take this into consideration (Matias, 2019). Having each person's preferences evaluated, the professional could provide a more adequate intervention to their clients/patients/students.

Also, more complementary questions could help improve the categorization system (e.g., to ask the participant to indicate the level of participation, such as recreational, competitive, amateur, as a trainer, etc). PA such as dance or swimming can be classified in different categories according to the context in which they are practiced, or the individual's attitude toward the activity. Another obvious limitation is that the greatest proportion of our sample belongs to university, thus hampering external validation.

Future studies could test several classification systems in the same data set, comparing the results and limitations of each one (F. L. Cardoso, 2019, personal communication). Based on the results, even a new and more comprehensive classification could be proposed.

A possible direction for future studies may be to develop classifications of PA based on previous systems, however with a broader spectrum of application. Development of more consistent categories of PA would allow interventions to provide more varied experiences, thus increasing chances for individuals to find more desirable or enjoyable PA. This has an important implication for practice: in Brazil, most schools fail to provide a great range of PA to students, offering almost exclusively the "Fantastic Four": Soccer, Volleyball, Basketball and Handball, even with hundreds of other PA and games available to offer. Our recent historical and cultural background also helps this scenario, since the open TV programs of sports cover almost exclusively football. 
Despite the limitations, our studies supported the proposal of four general types of PA- Individual Sport, Collective/Team Sport, Exercise and Body Practice, which showed to be an interesting categorization, although future studies can expand the spectrum of classification. For example, in Individual Sports, racquet sports and martial arts were grouped together, despite their great differences (e.g., in terms of physical contact). Another aspect not considered was the difference in energy expenditure within the categories: for example, in Exercises, walking and running, although both aerobic, can differ drastically regarding energy expenditure.

Chapter 2 highlights the need for more studies in order to rethink some aspects regarding classification of $\mathrm{PA}$, taking into account psychological variables, such as motivational factors. Having more open datasets available to compare, future authors may propose a classification system capable to integrate the best aspects from the existing classification systems.

With more data available, even automatized programs and apps can be developed, in which the individuals can answer questions regarding motives, thus having suggestions of PA as outputs. Another option could be an app that group PA according to each motivational criterion, e.g., people could look for Interest/Enjoyment, and receive suggestions of PA based on average means based on previous research.

\section{INSTRUMENTS AND PROCEDURES}

Regarding instruments, the findings of our studies also can help implementation of more personalized interventions. Strategies regarding promotion of PA are failing in part because there is a lack of attention toward psychological and social dimensions of PA (Matias, 2019).

By identifying individual differences (in personality, motivation, sociodemographic variables, and other factors) related with different types of PA, interventions can be more efficient to promote greater benefits in comparison to traditional interventions. Such older interventions use almost exclusively neuromotor and physiological measures, such as heart rate, balance, $\mathrm{VO}_{2}$, etc., but rarely use inventories regarding motives or personality. On the contrary, motives or personality are almost exclusively used for basic (non-applied) research purposes. Thus, we suggest the use of psychometrical measures as part of the assessment and evaluation protocols at gyms, schools, clubs, etc. 
Although comprehensive, the Motivation for Physical Activity Measure- Revised (Ryan et al., 1997) used in this study does not contemplate all subscales of motivations which would be relevant for our study, such as competitiveness and stress control. Future studies could use similar but more recent questionnaires. For example, the Physical Activity and Leisure Motivation Scales (PALMS), used by Molanorouzi et al. (2015), seems to be a good alternative. The PALMS contains more subscales (e.g., psychological condition and competition/ego) and only has a few more items than MPAM-R. Other questionnaires are also good options, such as Exercise Motivations Inventory (EMI), that also has more subscales than MPAM-R, including stress control and competitiveness (Markland \& Hardy, 1993).

Despite the limitations, we asked participants to answer MPAM-R regarding their most practiced PA, without specifying a domain, such as leisure (exceptions for walking and bicycling, present in the Wendel-Vos et al., 2003 "SQUASH" questionnaire, which is spliced by domains). This was important, since one person may do their primary PA in non-leisure domains, such as work (e.g., physical educators or professional athletes).

One may consider other measures, such as affective and hedonic measures, since traditional approaches regarding PA focus mainly on cognitive aspects, despite the importance of emotions and affective responses to PA maintenance (Matias, 2019).

Self-report measures, however, have some limitations, since they are not a direct measure, such as behavior recording or neurophysiological markers (Reeve, 2018). According to Bateson (1990), "understanding is significantly improved when the process involved in the development and integration of behavior are studied directly". An important part of motivation is unconscious. It is difficult to access these aspects through questionnaires, and ideally should be measured through processes that are not under conscious control.

Finally, some relevant data from our study are missing, since we have not had enough time to analyse all collected data. For example, almost $90 \%$ of the physically active individuals practiced PA for more than 6 months. These participants may differ significantly in their psychological profile from their counterparts that just started doing PA. This comparison will be explored in more detail in future publications. 


\section{SAMPLE AND FUTURE DIRECTIONS}

If developmental environment matters, differences are expected in each specific sample. Research in several species indicate developmental changes and prioritization of motivational systems as keyed to ecological inputs and pressures (Kenrick et al., 2010). So, differences of some of our results compared to samples from other countries, and even other Brazilian cities, may be accountable to such specific environmental differences.

An important aspect of our study was the criterion of inclusion: any person over 18 , physically active or not, could participate. This allowed participation of a broad sample, since participants of different physical activities and also sedentary participants contributed. Also, the proportion of sedentary and physically active participants was nearly $1: 1$. A possible biased sampling would recruit a far greater proportion of physically active participants. A large sample, such as ours, can still provide further analyses and also important implications to public health, such as more robust possibilities toward more personalized interventions according to each person's profile of personality, motivation, previous history regarding PA, etc.

Although some important data from sedentary participants were collected (such as personality, sociosexuality and sociodemographic data), others were not (e.g. motivations for PA). Thus, future studies could ask sedentary participants to indicate if in ideal conditions they would like to practice some PA, and if yes, which one, and for which motives. Next, sedentary participants could answer about barriers to PA participation (e.g., diseases or lack of free time), and also their motivations, with an instruction to indicate which motives seem to be more likely to initiate the activity reported as interesting. Also, we did not ask the non-active participants if they had practiced any PA in the past, which one and for how long. Motives for abandoning the PA would be of a great interest for future studies, since the interplay and prioritization among motives, threats, and opportunities are topics that need more empirical investigation (Kenrick et al., 2010). Regarding the above suggestions, we conducted a pilot study in 2019, however with only a small sample size not enabling to provide a valid analysis.

In addition, we believe our results will be more complete when we finish the analyses of our data. Limitations in time, personal and situational constraints forced to a reduction of goals in comparison to our initial research projects. Personality and 
individual differences, for example, are considered as important activators of motivational systems (e.g., the same opportunity or constraint is likely to be processed differently by different persons, thus influencing one's response). Two individuals can have completely different attitudes toward the same PA, since they have developed different values throughout their lives and these aspects should not be ignored. In addition, much research is still needed to clarify the ways in which individual differences interact with proximate motivational cues (Kenrick et al., 2010).

Another aspect to be explored is the importance of a teacher, since it is a key figure regarding motivation (Serrano et al., 2017). Having a model is an important source of self-efficacy (Bandura, 1977), so it is relevant to improve the PA professional's general condition, including monetary (paying better incomes for the services provided), logistic (a journey flexible enough to enable the professional take care of themselves doing some PA, instead of only watching the students), and also by providing better formation (including courses regarding motivation either in undergraduate as graduate course levels).

Instead of creating dependence in students, teachers/coaches might promote PA as a way to develop autonomy (Matias, 2019). For example, a stroke patient can recover lost movements after participating in programs of $\mathrm{PA}$, or elders can return to go alone in supermarkets after strength training (before the training, they had not sufficient muscular resistance to carry the bags). According to Grandino (2020), investing in an education system emphasizing affective and horizontal relations is a key to develop individuals with more autonomy. Regarding the self-determination theory, these aspects are crucial to successful interventions, because of the connection between autonomy and perception of competence (Ryan \& Deci, 2000).

Sedentarism has been a recurring public health concern during the past decades. However, recent technological advances, such as computers, videogames and smartphones that are considered as part of the problem, may be in reality part of the solution. As an example, we can cite the dissemination of electronic active games, that despite having their costs (e.g., money, electricity, eyes damage), can be used as possible sources of inspiration. Their use can be a cheaper way (e.g., in comparison to paying to experiment several physical activities, because the Brazilian's government restricted investments in public health) to develop positive impressions regarding PA, 
as electronic games basically promote fun and challenge (Cardoso, 2018), that are pillars of intrinsic motivations.

After liking one virtual PA, the individual could be directed to a specific program of such activity in real life context, also adding the health benefits to the already psychological gains associated with the videogame's intrinsic motivation. Successful interventions should foster autonomy, competence, and relatedness (Ryan \& Deci, $2000 b)$, since the quantity and quality of intrinsic motivation are directly related to the degree to which these needs are fulfilled (Weinberg \& Gould, 2018). In PA, it can be achieved through attitudes, such as sharing decisions with the client/patient/student, moderate levels of challenges and giving incentives to group formation and maintenance, such as social events outside of the PA sphere (Matias, 2019).

Further, it may be possible to show through PA how it is possible to overcome challenges. For example, despite extreme limitations during the COVID-19 pandemic, it is possible to use alternative ways to stay physically active, even without formal spaces, equipment, etc (Hammami, Harrabi, Mohr \& Krustrup, 2020). Such experience can be used as an example of how PA can transfer learning (in this case, to not give up and behavioral flexibility) to different contexts of life.

Since successful interventions to promote some PA during adolescence are associated with higher levels of PA during adulthood (Bélanger et al., 2015), another important future direction may be to compare persons of different ages regarding their motivation to do PA, and monitoring their developmental history. For example, individuals with more positive experiences with PA during childhood and adolescence might continue more active later into adulthood (i.e., a tracking effect, as reviewed by Azevedo Junior, 2011), and they might have more intrinsic motives. The same could be though about the sedentary: did they have, on average, fewer positive experiences during early development? Which barriers predominated?

\section{ADDITIONAL LIMITATIONS AND POTENTIALITIES ${ }^{8}$}

To deeper address the topics of the present research, future studies are encouraged to focus more on one of the aims of Ethology (Tinbergen, 1963), such as development/ontogeny or adaptive functions.

\footnotetext{
${ }^{8}$ Section added after the Doctoral defense (29/11/2021) suggestions from Prof. Dr. Patrícia Izar, Prof. Dr. Sandro Caramaschi, Prof. Dr. Marcelo Costa, Prof. Dr. Michele Schultz, and Prof. Dr. Fernando Cardoso.
} 
Future studies also need to be more careful when approaching sex differences, to avoid sexist biases. A very important point includes a possible bias in the scientific thinking associated with current developmental history and culture, which has a patriarchal tradition (Schultz, 2021; Smuts, 1995), possibly impacting several contexts, including scientists' hypotheses formulation presented in published papers in several published journals. Authors of future studies are encouraged to discuss their findings positioning themselves against or in support of the theories/authors they cited. Also, future researchers are expected to show concern or position themselves regarding hypothesis without enough theoretical and/or current support, or to provide alternative interpretations to findings from previous studies (e.g., greater appearance motives for physical activities in women).

Although less WEIRD than several North American or European samples, our sample is predominantly composed by a university population, which in 2016 (when data was collected) had for example, on average, greater familiar incomes and scholarship in comparison to most of the Brazilian population and regions ${ }^{9}$. Taking this into account, the previously formulated hypotheses may not have a precise fit with our sample. Also, external validation from our findings need to be analysed with caution. In addition, our sampling was through Snowball method, a convenience sampling, and thus have additional limitations and reduced explanative power compared to more representative randomized samplings. Also, more attention should be given to include analysis of important variables, such as socioeconomic status (e.g., not having enough money is an important barrier towards involvement in several PA). Despite our sample being composed of several PA, an additional and important limitation refers to the predominance of institutionalized/merchandized PA in a sample mostly of university students. Further studies could include also other cultures with different traditions regarding PA, such as Tarahumara and other contemporary hunter-gatherers. For example, Caldwell (2016) reviews several studies comparing energy expenditure from hunter gatherer societies, however, a possible filter according to the different PA practiced in each society would provide additional scientific improvements regarding potentials of different ways of being physically active. Thus, exploring more

\footnotetext{
${ }^{9}$ Affirmative measures, such as ethnical and public schools reserves are more recent at USP, and are supposed to result in a more democratic access to university for socially disadvantaged people, thus lowering the historical and structural social inequalities/injustices. See: https://jornal.usp.br/institucional/em-2021-usp-tem-mais-de-50-de-alunos-ingressantes-vindos-deescolas-publicas/
} 
manifestations of PA can shed light into new and more universal/broader categorizations of PA.

Our design was cross-sectional, thus having a limited explanative power. For example, the Fitness/Health motive can also be seemed as a barrier, since a person may be doing less PA because of a self-perception of lower health after developing a low self-perception of health associated with a recent increase in injuries frequency. In the same line, caution is needed when approaching extrinsic and intrinsic motives for doing PA. They should not be seen as dichotomic separated entities, but rather as belonging to an interplaying continuum, and all persons have all motives, although in different intensities. In addition, they may act simultaneously (e.g., a person is doing PA predominantly for appearance, an extrinsic motive, but can simultaneously experience feelings of satisfaction, enjoyment, competence, or other intrinsic motives).

Future studies should also address other variables capable to influence motivation. An important aspect not yet considered in our analysis is relationship status, which can reflect differences in resources oscillation as well. Future studies are welcome to take into account different life periods of an individual (e.g., a specific study focusing on comparing PA behavior of couples recently divorced/separated before and after their relationship termination). Also, additional analyses can be performed to improve understanding, such as multivariate non-linear statistics and medians/interquartile range. Topics such as sexual orientation, masculinity-femininity and cognitive gender also need to receive more attention, because they can have an explanative power even stronger than biological sex (Cardoso, 2021) ${ }^{10}$.

The present research combines originality with some explorations, and its results can be useful for innovating and improving public policies/technologies regarding health promotion through PAs practice.

We can group the main direct contributions of this research as follow: 1improvements regarding understanding of intrinsic and extrinsic motives applied to PA; 2- The persistence of similar patterns in distribution regarding motivational subscales even using completely different criteria to classify PA; 3- Differences regarding motivation and other individual differences in PA participation.

\section{FINAL CONSIDERATIONS}

10 Doctoral dissertation argument, 2021, november, 29. 
The present study, exploring individual differences in motives for practice of different types of physical activities and other related variables, through self-reported questionnaires, found consistent differences according to physical activity types, using 2 different analyses: either without major categories (Chapter 2), or by pre-categorizing them into sports, exercises and body/movement practices (Chapter 1). Also, relevant sex and age differences were found regarding motive's subscales of interest/enjoyment, appearance and fitness/health, or other variables, such as personality, sociossexuality and self-evaluations (Chapter 3 ).

This research contributed to advance understanding and discussion regarding classification systems of PA, focusing on its psychological mechanisms. The proposal of physical activity splitting into categories of Individual Sports, Collective Sports, Exercises and Body/Movement Practices showed to be consistent and also coherent, based on psychometric and motivational oriented analysis. We further identified possibilities to propose even more detailed classifications, including the measure of motives as an organizational criterion for PA classifications. Some PA consistently presented similar motivational scores when taking into account each subscale: interest/enjoyment, competence, social, appearance, and fitness/health. The subscales can help to develop applications regarding personalized health promotion programs of PA.

Another important contribution is that our results can help to construct new guidelines for orientation of community and training of health professionals. More informed individuals about different types of PA and their motivations are expected to better understand how PA work, which may facilitate their selection of specific PA. Better understanding of variations in personality, motives and sociodemographic factors and its associations with different types of PA can help to propose interventions more matched to each person's needs and aspirations. Although more research is needed, focused interventions are expected to lead to better maintenance of PA behavior than standard interventions that consider all individuals as completely equal. The field already takes individual differences into account regarding physiological and biomechanical variables (e.g., variations in intensity regarding person's blood pressure, heart rate, joint limitation in range of motion, etc.), but the same does not 
seem to be happening to the same extent regarding psychological variables. Why the body is being more valued than the mind regarding PA?

Possibly, more personalized interventions can either help to adopt specific type of PA that better fits the individual, and/or to improve maintenance. For example, it might be efficient to suggest PA that matches each person's answers in the initial stages of involvement in PA, while in the long-term suggesting PA that may be dissonant a little bit from the person's initial scores, aiming to provide new challenges and more learning about the universe of PA, as self-knowledge.

Also, more evolutionary based research on PA is needed, exploring additional variables than in our study. 


\section{REFERENCES}

Aaltonen, S., Latvala, A., Rose, R. J., Pulkkinen, L., Kujala, U. M., Kaprio, J., \& Silventoinen, K. (2015). Motor development and physical activity: a longitudinal discordant twin-pair study. Medicine and science in sports and exercise, 47(10), 2111.

Aaltonen, S., Leskinen, T., Morris, T., Alen, M., Kaprio, J., Llukkonen, J., \& Kujala, U. M. (2012). Motives for and Barriers to Physical Activity In Twin Pairs Discordant for Leisure Time Physical Activity for 30 Years. International Journal of Sports Medicine, 33, 157-163.

Aaltonen, S., Kujala, U. M., \& Kaprio, J. (2014). Factors behind Leisure-Time Physical Activity Behavior Based on Finnish Twin Studies: The Role of Genetic and Environmental Influences and the Role of Motives. BioMed Research International, 2014, p. 1-8.

Ades, C. (2009). Um olhar Evolucionista para a Psicologia. In: Otta, E., Yamamoto, M. Psicologia Evolucionista. Rio de Janeiro: Guanabara Koogan.

Ades, C. (1980/2018). Motivação animal: Da equilibração clássica à perspectiva ecológica. In: Izar, P., Gomide, P. I. C. Para além da dicotomia inato-aprendido: Contribuições de César Ades à Psicologia Brasileira. Ribeirão Preto: SBP, 95102.

Ades, C. (1984/2018). Sobre a motivação: Notas à margem de um capítulo sobre motivação. In: Izar, P., Gomide, P. I. C. Para além da dicotomia inato-aprendido: Contribuições de César Ades à Psicologia Brasileira. Ribeirão Preto: SBP, 8393.

Alcock, J. (2011). Comportamento animal: uma abordagem evolutiva (9 ${ }^{\mathrm{a}}$ ed.). Porto Alegre: Artmed.

Alves, F., \& Carvalho, Y. (2010). Práticas corporais e grande saúde: um encontro possível. Movimento (ESEF/UFRGS), 16(4), 229-244.

Apostolou, M. (2015). The Athlete and the Spectator Inside the Man: A Cross-Cultural Investigation of the Evolutionary Origins of Athletic Behavior. Cross-Cultural Research, 49(2), 151-173.

Apostolou, M., \& Lambrianou, R. (2017). What Motivates People to Do and Watch Sports? Exploring the Effect of Sex, Age, Partner Status, and Parenthood. Evolutionary Psychological Science, 1-14.

Apostolou, M., \& Shialos, M. (2017). Why Men Hunt and Women Gather for Recreation? An Evolutionary Perspective. Evolutionary Psychological Science, 1-9. 
Azevedo Junior, M. R. (2011). Tracking da Atividade Física ao Longo da Vida. In: Florindo, A. A. Hallal, P. C. Epidemiologia da Atividade Física. São Paulo: Atheneu.

Balbinotti, M., \& Barbosa, J. (2009).Aspectos motivacionais do tenista: prazer versus competitividade. In: Balbinotti, C. O ensino do tênis: novas perspectivas de aprendizagem. Porto Alegre: Artmed.

Bandura, A. (1977). Self-efficacy: Toward a unifying theory of behavioral change. Psychological Review, 84(2), 191-215.

Barbanti, V. (2003). Dicionário de educação física e esporte. (2ª ed.). Manole.

Barbosa, M. L. L. (2006). Propriedades métricas do inventário de motivação à prática regular de atividade física (IMPRAF-126) (Master Thesis). Universidade Federal do Rio Grande do Sul.

Barreira, C. R. A. (2018). Essência da Luta e Artes Marciais. In: III Congresso da Associação Latina de Filosofia do Esporte.

Barroso, A. L. R., \& Darido, S. C. (2019). Compreensão e avaliação de um modelo de classificação do esporte na educação física escolar: visão de professores. Conexões, 17, e019011.

Bateson, P. (1991). Are there principles of behavioural development? In P. Bateson (Ed.), The development and integration of behaviour: Essays in honour of Robert Hinde. Cambridge University Press.

Bateson, P. (1991). Levels and processes. In: Bateson, P. (Ed.) The development and integration of behaviour: Essays in honour of Robert Hinde. Cambridge University Press.

Batia, A. (2007). Relationships among personality, self-determination and exercise behavior (Doctoral Dissertation), University of Florida.

Baumeister, R. (2016). Toward a general theory of motivation: Problems, challenges, opportunities, and the big picture. Motivation and Emotion, 1-10.

Behncke, I. (2018). From play in wild bonobos to festivals in both Neolithic and contemporary humans. In: Annals of the XXIV Biennial Conference on Human Ethology. International Society for Human Ethology (81), Santiago, CL.

Bélanger, M., Sabiston, C. M., Barnett, T. A., O'Loughlin, E., Ward, S., Contreras, G., \& O'Loughlin, J. (2015). Number of years of participation in some, but not all, types of physical activity during adolescence predicts level of physical activity in adulthood: Results from a 13-year study. International Journal of Behavioral Nutrition and Physical Activity, 12(1), 1-8. 
Bovet, J. (2020). Evolutionary Theories and Men's Preferences for Women's Waist-toHip Ratio: Which Hypotheses Remain? A Systematic Review. Frontiers in Psychology 10: 1221.

Brasil (2010). Ministério da Saúde. Secretaria de Vigilância em Saúde. Política Nacional de Promoção da Saúde. 3rd ed. Brasília: Ministério da Saúde.

Buss, D. (2009). How can evolutionary psychology successfully explain personality and individual differences? Perspectives on Psychological Science, 4(4), 359366.

Bussab, V., \& Ribeiro, F. (1998). Biologicamente Cultural. In: Rodrigues, M. \& Freitas, M. (1998). Psicologia: reflexões (im)pertinentes. São Paulo: Casa do Psicólogo.

Cacioppo, J. T., Hawkley, L. C., Norman, G. J., \& Berntson, G. G. (2011). Social isolation. Annals of the New York Academy of Sciences, 1231(1), 17-22.

Caldwell, A. E. (2016). Human physical fitness and activity: an evolutionary and life history perspective. Springer.

Cardoso, F. L. (2018). Apropriação das novas tecnologias digitais aplicadas a psicologia do exercício e do esporte: uma experiência de pesquisadores não Programadores. Presentation at XVII Congresso Brasileiro e X Congresso Internacional de Psicologia do Esporte: Psicologia e a Busca da Excelência esportiva. Curitiba.

Cardoso, F. L., Medeiros, T. E., Da Silva, W. R., Ferrari, E. P., \& de Melo, G. F. (2020). A vivência de práticas físicas/motoras/esportivas de homens e mulheres para propor o construto orientação esportiva. Revista Brasileira de Educação Física e Esporte, 34(3), 395-404.

Cardoso, F. L., \& Sacomori, C. (2012). Identidade de gênero/sexo de atletas e sedentários. Revista Brasileira de Ciências do Esporte, 34(4), 925-941.

Cardoso, F. L., Silveira, R. A., Zequinão, M. A., Martins, C., \& Souza, C. A. (2010). Autopercepção corporal e preferências motoras de praticantes de dança. Movimento, 16(1), 97-112.

Carvalho, Y. M. (2006). Promoção da saúde, práticas corporais e atenção básica. Revista Brasileira Saúde da Família, 33-45.

Carvalho, Y. M., \& Manoel, E. D. J. (2015). A survey of body practices and primary health care in a district of São Paulo, Brazil. Motriz: Revista de Educação Física, 21(1), 75-83.

Castañeda-Babarro, A., Arbillaga-Etxarri, A., Gutiérrez-Santamaría, B., \& Coca, A. (2020). Physical activity change during COVID-19 confinement. International journal of environmental research and public health, 17(18), 6878. 
Coolican, H. (2014). Research methods and statistics in psychology. New York: Psychology Press.

Costa, E. F., Salvador, E. P., Guimarães, V. V., \& Florindo, A. A. Atividade física em diferentes domínios e sua relação com a escolaridade em adultos do distrito de Ermelino Matarazzo, Zona Leste de São Paulo, SP. Revista Brasileira de Atividade Física e Saúde. 2012;15(3):151-6.

Crawford, C., \& Krebs, D. (2008). Foundations of evolutionary psychology. 2nd ed. Psychology Press.

Cunha, A. R. M. D. (2018). Estudo qualitativo sobre as experiências de um grupo de utilizadores do Tinder (Master thesis). Porto: Universidade Fernando Pessoa.

De Block, A., \& Dewitte, S. (2009). Darwinism and the cultural evolution of sports. Perspectives in Biology and Medicine, 52(1), 1-16.

De Rose Jr, D, \& Silva T. (2006). Modalidades esportivas coletivas. Rio de Janeiro: Guanabara Koogan.

Deaner, R. O., Balish, S. M., \& Lombardo, M. P. (2015). Sex differences in sports interest and motivation: An evolutionary perspective. Evolutionary Behavioral Sciences, 10(2), 73.

Deaner, R. O., \& Smith, B. A. (2013). Sex differences in sports across 50 societies. Cross-Cultural Research, 47(3), 268-309.

Dias, R. G., Pereira, A. C., Negrão, C. E., \& Krieger, J. E. (2007). Polimorfismos genéticos determinantes da performance física em atletas de elite. Revista Brasileira de Medicina do Esporte, 13(3), 209-216.

Domenico, S., \& Ryan, R. M. (2017). The emerging Neuroscience of Intrinsic Motivation: A New Frontier in Self-Determination Research. Frontiers in Human Neuroscience, 11.

Duranso, C. W. (2019). Walk for well-being: The main effects of walking on approach motivation. Motivation and Emotion, 43(1), 93-102.

Durstine J. L., Gordon B., Wang Z., \& Luo X. (2013). Chronic disease and the link to physical activity. Journal of Sport Health Sciences., 2(1), 3-11.

Enoka, R. M. (2008). Neuromechanics of human movement. Champaign, Human Kinetics.

Farias Júnior, J. C. (2011). (In) atividade física e comportamento sedentário: estamos caminhando para uma mudança de paradigma? Revista Brasileira de Atividade Física \& Saúde, 16(4), 279-280. 
Faurie, C., Pontier, D., \& Raymond, M. (2004). Student athletes claim to have more sexual partners than other students. Evolution and Human Behavior, 25(1), 18.

Ferreira R. (2011). Causas próximas e causas distais na compreensão do comportamento animal. In M.E. Yamamoto, G.L. Volpato, Comportamento Animal (pp. 65-78) (2nd ed.). Natal, RN: EDUFRN.

FitzGibbon, C. D., \& Fanshawe, J. H. (1988). Stotting in Thomson's gazelles: an honest signal of condition. Behavioral Ecology and Sociobiology, 23(2), 69-74.

Florindo, A. A. (2011) Atividade física e doenças crônicas. In: Florindo, A. A. Hallal, P. C. Epidemiologia da Atividade Física. São Paulo: Atheneu.

Florindo, A. A., Guimarães, V. V., Cesar, C. L. G., de Azevedo Barros, M. B., Alves, M. C. G. P., \& Goldbaum, M. (2009). Epidemiology of leisure, transportation, occupational, and household physical activity: prevalence and associated factors. Journal of Physical Activity and Health, 6(5), 625-632.

Fortes, M. (1936). Ritual festivals and social cohesion in the hinterland of the Gold Coast. American Anthropologist, 38(4), 590-604.

Franks, B., Higgins, E. T., \& Champagne, F. A. (2014). A Theoretically Based Model of Rat Personality with implications for Welfare. Plos One, 9(4), 1-9.

Frederick, C., \& Ryan, R. M. (1993). Differences in motivation for sport and exercise and their relations with participation and mental health. Journal of Sport Behavior, 16(3), 124-146.

Freire, P. (1996). Pedagogia da autonomia. São Paulo: Paz e Terra

Gentile, B., Miller, J., Hoffman, B., Reidy, D., Zeichner, A., \& Campbell, W. (2013). A test of two brief measures of grandiose narcissism: The Narcissistic Personality Inventory-13 and the Narcissistic Personality Inventory-16. Psychological Assessment, 25(4), 1120-1136.

Gonçalves, M. P., \& Alchieri, J. C. (2010). Motivação à prática de atividades físicas: um estudo com praticantes não-atletas. Psico USF, 15(1), 125-134.

Gonzalez, F. J. (2004). Sistema de classificação de esportes com base nos critérios: cooperação, interação com o adversário, ambiente, desempenho comparado e objetivos táticos da ação. Lecturas: Educación física y deportes, (71), 3.

Gonzalez, F. J., Fensterseifer, P. E. (2014). Preface. In: Dicionário Crírico de Educação Física (3rd ed.). Ijuí: Unijuí.

Gosling, S. D. (2001). From mice to men: what can we learn about personality from animal research? Psychological Bulletin, 127(1), 45. 
Gosling, S. D., \& John, O. P. (1999). Personality dimensions in nonhuman animals: A cross-species review. Current directions in psychological science, 8(3), 69-75.

Gosso, Y., Otta, E., Morais, M. L. S., Ribeiro, F. J. J., \& Bussab, V. S. R. (2005). Play in Hunther-Gatherer Society. In: Pellegrini, A. D., Smith, P. K. The Nature of Play: Great Apes and Humans. New York/London: Guilford Press (213-253).

Grandino, P. J. (2020). Formar-se professor, formar-se educador: uma leitura psicanalítica de relatos autobiográficos. Curitiba, Appris.

Guerriero, I. C. Z., Schmidt, M. L. S., \& Zicker, F. (2008). Ética nas pesquisas em ciências humanas e sociais na saúde. São Paulo: Aderaldo \& Rothschild.

Hammami, A., Harrabi, B., Mohr, M., \& Krustrup, P. (2020). Physical activity and coronavirus disease 2019 (COVID-19): specific recommendations for homebased physical training. Managing Sport and Leisure, 1-6.

Harman, V., \& Wong, Y. N. (2020). Same-sex Pairings on Strictly Come Dancing: LGBTQ+ Identity and Leisure Participation in Ballroom Dancing. In: Positive Sociology of Leisure. Palgrave Macmillan, Cham.

Heckhausen, J. E., \& Heckhausen, H. E. (2018). Motivation and action. Cambridge University Press.

Hinde, R. (1991). Commentary 2. In: Bateson, P. (Ed.) The development and integration of behaviour: Essays in honour of Robert Hinde. Cambridge University Press.

Hoffman, S. (2013). Introduction to kinesiology: studying physical activity. (4⿳亠丷⿵冂丶 ed.) Human Kinetics.

Hooper, P. L., \& Miller, G. F. (2008). Mutual mate choice can drive costly signaling even under perfect monogamy. Adaptive Behavior, 16(1), 53-70.

Howle, T. C., Jackson, B., Conroy, D. E., \& Dimmock, J. A. (2015). Winning friends and influencing people: Self-presentation motives in physical activity settings. International Review of Sport and Exercise Psychology, 8(1), 44-70.

Kavanagh, P. S., \& Scrutton, H. E. (2015). Self-Esteem. In: Zeigler-Hill, V., Welling, L. L., \& Shackelford, T. K. (Eds.). Evolutionary perspectives on social psychology. Springer.

Kennedy, B. K., Berger, S. L., Brunet, A., Campisi, J., Cuervo, A. M., Epel, E. S., ... \& Rando, T. A. (2014). Geroscience: linking aging to chronic disease. Cell, 159(4), 709-713.

Kenrick, D. T., Griskevicius, V., Neuberg, S. L., \& Schaller, M. (2010). Renovating the pyramid of needs: Contemporary extensions built upon ancient foundations. Perspectives on psychological science, 5(3), 292-314. 
Kerr, J. H. (1997). Motivation And Emotion In Sport. Taylor \& Francis.

Kilpatrick, M., Hebert, E., \& Bartholomew, J. (2005). College students' motivation for physical activity: differentiating men's and women's motives for sport participation and exercise. Journal of American College Health, 54(2), 87-94.

Lane, A. (2008). Sport and Exercise Psychology: Topics in Applied Psychology. London: Hodder Education

Larsen, S., Mozdoorzoy, T., Kristiansen, E., Falch, H. N., Aune, T. K., van den Tillar, R. (2021). A Comparison of Motives by Gender and Age Categories for Training at Norwegian Fitness Centers. Sports, 9 (113),

Lazzarotti Filho, A., Silva, A. M., Antunes, P. D. C., Da Silva, A. P. S., \& Leite, J. O. (2010). O termo práticas corporais na literatura científica brasileira e sua repercussão no campo da Educação Física. Movimento, 16(1), 11-29.

Leary, M. R. (2001). Toward a conceptualization of interpersonal rejection. Interpersonal rejection, 3-20.

Leary, M. R., Tambor, E. S., Terdal, S. K., \& Downs, D. L. (1995). Self-esteem as an interpersonal monitor: the sociometer hypothesis. Journal of personality and social psychology, 68(3), 518.

Lee, K., \& Ashton, M. C. (2004). Psychometric properties of the HEXACO personality inventory. Multivariate behavioral research, 39(2), 329-358.

Lee-Manoel, C. (2002). O Corpo em movimento gerando auto-conhecimento. In: Corpo, Prazer e Movimento. Serviço Social do Comércio.

Lent, R. (2010). Cem Bilhões de Neurônios? Conceitos fundamentais de neurociência. ( $2^{\mathrm{a}}$ ed.) São Paulo: Atheneu.

Lieberman, D. E. (2020). Exercised: Why something We never evolved to do is healthy and rewarding. New York, NY: Knopf Doubleday Publishing Group, 2021.

Harlow, H. (1958). The nature of love. American psychologist, 13(12), 673-685.

Izar, P. (2009). Ambiente de Adaptação Evolutiva. In Otta E, Yamamoto, ME. Psicologia Evolucionista (pp. 22-32). São Paulo: Guanabara Koogan.

Malta, D. C., Moura, E. C., Castro, A. M., Cruz, D. K. A., Morais Neto, O. L., \& Monteiro, C. A. Padrão de atividade física em adultos brasileiros: resultados de um inquérito por entrevistas telefônicas, 2006. Epidemiologia e Serviços de Saúde. 2009 Mar;18(1):7-16.

Maraz, A., Király, O., Urbán, R., Griffiths, M. D., \& Demetrovics, Z. (2015). Why do you dance? Development of the Dance Motivation Inventory (DMI). PloS one, 10(3), e0122866. 
Markland, D., \& Hardy, L. (1993). The Exercise Motivations Inventory: Preliminary development and validity of a measure of individuals' reasons for participation in regular physical exercise. Personality and Individual Differences, 15(3), 289296.

Marshall, T., Lefringhausen, K., \& Ferenczi, N. (2015). The Big Five, self-esteem, and narcissism as predictors of the topics people write about in Facebook status updates. Personality and Individual Differences, 85, 35-40.

Maslow, A. (1943). A theory of human motivation. Psychological review, 50(4), 370396.

Matias, T. (2019). Motivação, atividade física e mudança de comportamento: teoria e prática. Curitiba: Appris.

McCrae, R. R., \& John, O. P. (1992). An introduction to the five-factor model and its applications. Journal of personality, 60(2), 175-215.

Meira Jr, C. M., Meneguelli, K. S., Leopoldo, M. P., \& Florindo, A. A. (2020). Anxiety and Leisure-Domain Physical Activity Frequency, Duration, and Intensity During Covid-19 Pandemic. Frontiers in Psychology, 11, 3758.

Meira Jr., C. M., De Rose Jr., D., \& Massa, M. (2020). Iniciação aos esportes coletivos. São Paulo: Edições EACH.

Molanorouzi, K., Khoo, S., \& Morris, T. (2015). Motives for adult participation in physical activity: type of activity, age, and gender. BMC Public Health, 15(1), 66.

Moran, A. (2004). Sport and exercise psychology: A critical introduction. London: Routledge.

Natividade, J., \& Hutz, C.. (2015). Escala Reduzida de Descritores dos Cinco Grandes Fatores de Personalidade: Prós e Contras. Psico, 46(1), 79-89.

Nogueira J. A. D., \& Moreno, R. (2011). Educação Física e Saúde. In Universidade de Brasília. Educação Física a distância: módulo 7 (pp. 133-210) (2nd ed.). Brasília, DF: UnB.

O'Brien, D. T., \& Gallup, A. C. (2011). Using Tinbergen's four questions (plus one) to facilitate evolution education for human-oriented disciplines. Evolution: Education and Outreach, 4(1), 107-113.

Panksepp, J. Affective neuroscience: the foundations of human and animal emotions. New York, Oxford.

Penke, L., \& Asendorpf, J. (2008). Beyond global sociosexual orientations: A more differentiated look at sociosexuality and its effects on courtship and romantic relationships. Journal of Personality and Social Psychology, 95(5), 1113-1135. 
Prochaska, J. O. (2008). Decision making in the transtheoretical model of behavior change. Medical decision making, 28(6), 845-849.

Prochaska, J. O., \& Diclemente, C. C. (1983). Stages and processes of self-change of smoking: toward an integrative model of change. Journal of consulting and clinical Psychology, 51(3), 390-395.

Purwanto, A., Asbari, M., Fahlevi, M., Mufid, A., Agistiawati, E., Cahyono, Y., \& Suryani, P. (2020). Impact of work from home (WFH) on Indonesian teachers performance during the Covid-19 pandemic: An exploratory study. International Journal of Advanced Science and Technology, 29(5).

Reeve, J. (2018). Understanding motivation and emotion. $7^{\text {th }}$ ed. John Wiley \& Sons.

Resende, B. (2018). O corpo, o lúdico, e o bem-viver. Psicologia USP, 29(3), 323-324.

Resende, B.D., Izar, P., \& Ottoni, E. B. (2004). Social Play and Spatial Tolerance in Tufted Capuchin Monkeys (Cebus apella). Revista de Etologia, 6(1), 55-61.

Rhodes, R., \& Smith, E. (2006). Personality correlates of physical activity: a review and meta-analysis. Brazilian Journal of Sports Medicine, 40, 958-965.

Rosa, J. P., de Souza, A. A., de Lima, G. H., Rodrigues, D. F., de Aquino Lemos, V., da Silva Alves, E., ... \& de Mello, M. T. (2015). Motivational and evolutionary aspects of a physical exercise training program: a longitudinal study. Frontiers in psychology, 6, 648.

Ryan, R. M., \& Deci, E. L. (2000a). Intrinsic and Extrinsic Motivations: Classic Definitions and New Directions. Contemporary Educational Psychology, 25, 5467.

Ryan, R. M., \& Deci, E. L. (2000b). Self-determination theory and the facilitation of intrinsic motivation, social development, and well-being. American psychologist, 55(1), 68.

Ryan, R., Frederick, C., Lepes, D., Rubio, N., \& Sheldon, K. (1997). Intrinsic motivation and exercise adherence. International Journal of Sport Psychology, 28, 335354.

Salles-Costa R., Heilborn, M. L., Werneck, G. L., Faerstein, E., Lopes, C. S. (2003). Gênero e prática de atividade física de lazer. Cadernos de Saúde Publica.;19:S325-33.

Sanches, S. M., Rubio, K. The Search for Excellence: Motivations, Difficulties and the Adaptation Process of Athletes from Distinct Regions of Brazil. Book of Abstracts of World Congress of Sociology of Sport. Utrecht, 2009.

Schmitt, D. (2005). Sociosexuality from Argentina to Zimbabwe: a 48-nation study of sex, culture, and strategies of human mating. The Behavioral and Brain Sciences, 28(2), 247-275. 
Schmitt, D. P., \& Shackelford, T. K. (2008). Big Five traits related to short-term mating: From personality to promiscuity across 46 nations. Evolutionary Psychology, 6(2), 246-282.

Schultz, M. (2021). Machismo: toxina que degrada o meio esportivo. Revista Brasileira De Educação Física E Esporte, 35(Especial), 71-76.

Serrano, J. S., Solana, A. A., Catalán, Á. A., \& González, L. G. (2017). El clima motivacional del docente de Educación Física:: ¿ Puede afectar a las calificaciones del alumnado?. Retos: nuevas tendencias en educación física, deporte y recreación, (31), 98-102.

Spinka, M. (2019). The unity and differentiation on mammalian play. Plenary presented at the XXXVII Encontro Annual de Etologia. São Paulo: Sociedade Brasileira de Etologia.

Streb, A. R., Matias, T. S., Leonel, L. D. S., Tozetto, W. R., Vieira, C. G., \& Del Duca, G. F. (2019). Association between physical inactivity in leisure, work, commuting, and household domains and nutritional status in adults in the capital cities of Brazil. Revista de Nutrição, 32.

Swami, V., Diwell, R., \& McCreary, D. (2014). Sexuality and the drive for muscularity: Evidence of associations among British men. Body image,11(4), 543-546.

Tavakol, M. \& Dennick, R. (2011). Making sense of Cronbach's alpha. International jounal of of medical education, 2, 53.

Taylor, S. E., Klein, L. C., Lewis, B. P., Gruenewald, T. L., Gurung, R. A. R., \& Updegraff, J. A. (2000). Biobehavioral responses to stress in females: Tendand-befriend, not fight-or-flight. Psychological Review, 107(3), 411-429.

Teixeira, F., Medeiros, P., Cardoso, A., Sperandio, F., \& Cardoso, F. (2015). Um panorama acerca da produção científica nacional sobre educação física e sexualidade. Revista Arquivos de Ciências da Saúde, 22(1), 59-63.

Timmermans, E., \& De Caluwé, E. (2017). To Tinder or not to Tinder, that's the question: An individual differences perspective to Tinder use and motives. Personality and Individual Differences, 110, 74-79.

Tinbergen, N. (1963). On aims and methods of Ethology. Zeitschrift Für Tierpsychologie, 20(4), 410-43.

Dörnyei, Z. \& Ushioda, E. (2011). Teaching and researching: Motivation. Pearson Education.

Valentova, J. V., Bártová, K., Štěrbová, Z., \& Varella, M. A. C. (2017). Influence of sexual orientation, population, homogamy, and imprinting-like effect on preferences and choices for female buttock size, breast size and shape, and WHR. Personality and Individual Differences, 104, 313-319. 
Valentova, J. V., \& Varella, M. A. C. (2016). Further Steps Toward a Truly Integrative Theory of Sexuality. Archives of sexual behavior, 45(3), 517-520.

Valentova, J. V., Štěrbová, Z., Bártová, K., \& Varella, M. A. C. (2016). Personality of ideal and actual romantic partners among heterosexual and non-heterosexual men and women: A cross-cultural study. Personality and Individual Differences, 101, 160-166.

Vancampfort, D., Hallgren, M., Firth, J., Rosenbaum, S., Schuch, F. B., Mugisha, J., ... \& Stubbs, B. (2018). Physical activity and suicidal ideation: A systematic review and meta-analysis. Journal of affective disorders, 225, 438-448.

Varella, M. A. C. Mal-entendidos sobre a Psicologia Evolucionista. In: Yamamoto, M. E., Valentova, J. V (orgs). Manual da Psicologia Evolucionista. Natal: Edufrn.

Varella, M. A., Valentova, J. V., \& Fernández, A. M. (2015). Evolution of artistic and aesthetic propensities through female competitive ornamentation. In Fisher, M., L. The Oxford Handbook of Women and Competition.

Vergeer, I. (2018) Participation motives for a holistic dance-movement practice, International Journal of Sport and Exercise Psychology, 16:2, 95-111

Von Frisch, K. (1974). Decoding the language of the bee. Science, 185(4152), 663668.

Weinberg, R. S., \& Gould, D. (2015). Foundations of Sport and Exercise Psychology (6th ed.). Champaign: Human Kinetics.

Weinberg, R. S., \& Gould, D. (2018). Foundations of Sport and Exercise Psychology (7th ed.). Champaign: Human Kinetics.

Wendel-Vos, G., Schuit, A., Saris, W., \& Kromhout, D. (2003). Reproducibility and relative validity of the short questionnaire to assess health-enhancing physical activity. Journal of clinical epidemiology, 56(12), 1163-1169.

Winegard, B., \& Deaner, R. O. (2010). The evolutionary significance of Red Sox Nation: Sport fandom as a byproduct of coalitional psychology. Evolutionary Psychology, 8(3), 432-446.

Wilson, K., \& Dishman, R. (2015). Personality and physical activity: A systematic review and meta-analysis. Personality and Individual Differences,72, 230-242.

Wlodkowski, R. J. (2008). Enhancing adult motivation to learn: A comprehensive guide for teaching all adults ( $3^{\text {rd }}$ ed.). John Wiley \& Sons.

Wood W., Eagly A. H. (2002). A cross-cultural analysis of the behavior of women and men: implications for the origins of sex differences. Psychological Bulletin. Sep;128(5):699-727. 
Yamamoto, M. (2009). Introdução: Aspectos Históricos. In: Otta, E., \& Yamamoto, M. Psicologia Evolucionista. Rio de Janeiro: Guanabara Koogan.

Yavari, Y. (2014). Narcissism and Its Relations With Beliefs About Body Appearance and Personal Characteristics Among Elite Body Builders. International Journal of Sport Studies; 4(4), 394-399. 


\section{APPENDIX 1- INFORMED CONSENT TERM}

\section{INFORMAÇÕES PARA O PARTICIPANTE}

Você está sendo convidado(a) a participar de um estudo. Antes de tomar sua decisão, é importante que você entenda o porquê desta pesquisa e o que envolverá. Por favor, reserve algum tempo para ler as seguintes informações atentamente e sinta-se à vontade para entrar em contato conosco se quiser mais informações ou se tiver alguma dúvida. É necessário enfatizar que você não é obrigado(a) a aceitar este convite e deve participar apenas se quiser.

\section{Objetivos do estudo}

O objetivo deste estudo é explorar relações entre aspectos da personalidade com motivações para prática de atividades físicas. Esta pesquisa faz parte do Trabalho de Conclusão de Curso de autoria de Rafael Ming Chi Santos Hsu (Bacharelando em Educação Física e Saúde da Universidade de São Paulo), sob orientação da Prof. ${ }^{a}$ Dr. ${ }^{\text {a }}$ Jaroslava Varella Valentova (Docente do instituto de Psicologia da Universidade de São Paulo),

\section{Por que eu deveria participar?}

Sua participação é muito importante, vai nos ajudar a entender melhor, por exemplo, por que pessoas tendem a dar preferência por determinado tipo de atividade e não outro, além de proporcionar ao próprio participante a possibilidade de se conhecer melhor, ao responder os questionários de personalidade. É importante destacar também que você pode participar mesmo se no momento não estiver praticando alguma atividade física com regularidade. Sua participação será muito importante para nós! Agradecemos também se puder ajudar-nos a divulgar para todos os seus amigos e contatos!

\section{Descrição e riscos do estudo}

Caso aceite participar do estudo ao aceitar este Termo de Consentimento Livre e Esclarecido, você será solicitado(a) a responder alguns questionários. Todo o processo deve levar em média 25 minutos para ser concluído, mas caso você não consiga responder tudo na hora, é possível continuar em outro momento, através do mesmo aparelho (computador, celular ou tablet) e link pois a pesquisa é salva automaticamente.

Completada a sua participação, e caso queira obter mais informações sobre o projeto, ou receber um relatório com os principais resultados que forem encontrados, favor entrar em contato com o pesquisador responsável através do email: rafa.mcsh@gmail.com

Pediremos que você forneça alguns de seus dados sociodemográficos, além de responder a alguns questionários.

Quanto aos riscos envolvidos com a participação na pesquisa, é possível que haja algum desconforto com algumas das questões, que podem despertar sentimentos ambíguos. 


\section{Sigilo e Divulgação de Informações}

Todas as suas respostas serão armazenadas de forma anônima e segura. Os resultados serão analisados quantitativamente de forma global e os resultados gerais divulgados de forma coletiva em forma de apresentação em congressos e/ou artigos científicos.

Você também pode interromper sua participação a qualquer momento e seus dados não serão utilizados durante as análises.

Caso tenha dúvidas, preocupações após sua participação, ou queira receber uma cópia deste Termo de Consentimento, entre em contato com Rafael Ming Chi Santos Hsu (rafael.hsu@usp.br) ou Professora Dr. a Jaroslava Varella Valentova (jaroslava@usp.br). Se tiver algum desconforto em decorrência da participação nesta pesquisa,você pode entrar em contato com serviços de ajuda psicológica, tais como a Clínica Psicológica do instituto de Psicologia da USP (E-mail: clinica@usp.br, Telefone: (11) 3091-8248 / 3091-8223)

\section{Não existem respostas "certas" ou "erradas". Também pedimos que responda da forma mais sincera, espontânea e honesta possível.}

A participação neste estudo é completamente voluntária e você está livre para desistir a qualquer momento.

Para esclarecimentos com relação às dúvidas éticas do projeto, pode-se também entrar em contato com o Comitê de Ética em Pesquisa com Seres Humanos do Instituto de Psicologia da Universidade de São Paulo, localizado na Av. Professor Mello Moraes, 1721 - Bloco G, $2^{\circ}$ andar, sala 27 CEP 05508-030 - Cidade Universitária - São Paulo/SP E-mail: ceph.ip@usp.br - Telefone: (11) 3091-4182

\section{Seu consentimento}

Eu declaro estar informado(a) das condições de participação na pesquisa "Relações entre Aspectos da Personalidade com a Motivação para Prática de Atividades Físicas" e ter livre interesse em participar. Declaro também estar informado de todas as condições para participação. Eu reconheço que minha participação é anônima e as minhas informações fornecidas serão estritamente confidenciais e usadas apenas para fim de pesquisa científica.

O Aceito participar

O Não aceito participar 


\section{APPENDIX 2- SOCIODEMOGRAPHIC QUESTIONNAIRE}

Sexo

O Masculino

Feminino

O Outro

(Escala) De 1 (exclusivamente heterossexual) a, 7 (exclusivamente homossexual), qual a sua orientação sexual?

Idade (anos) : menos de 18, 18 a 80 (opções individuais entre este intervalo disponíveis), mais de 80

\section{Escolaridade}

- Ensino fundamental incompleto

- Ensino fundamental completo

- Ensino médio incompleto

- Ensino médio completo

Ensino superior incompleto

- Ensino superior completo

- Ensino superior completo- Especialização

- Ensino superior completo- Mestrado

- Ensino superior completo- Doutorado

Renda familiar mensal (soma de todas as pessoas que moram com você)

O Até 1 salário mínimo

O Entre 1 e 3 salários mínimos

O Entre 3 e 5 salários mínimos

O Entre 5 e 10 salários mínimos

○ Acima de 10 salários mínimos

Peso (kg):menos de 45, 45 a 125 (opções individuais entre este intervalo disponíveis), mais de 125

Altura (cm): abaixo de 130 , 130 a 200 (opções individuais com intervalos de $5 \mathrm{~cm}$ disponíveis), acima de 200

(Escala) De 1 (nem um pouco religioso) a, 7 (extremamente religioso), o quão religioso você se considera? 
Qual a sua religião?

O Católico

O Protestante/Evangélico

Espírita

Outra (qual?)

O Nenhuma

\section{Etnia}

O Negra

O Oriental

O Branca

O Parda

O Indígena

Outra (qual?)

(Escala) De 1 (péssima) a 7 (excelente), como você avalia sua saúde?

(Escala) De 1 (péssima) a 7 (excelente), como você avalia sua atratividade?

Estado civil atual

O Casado(a)

O Solteiro(a)

O Viúvo(a)

O Divorciado(a)/Separado(a)

O Outro tipo de relacionamento sério

Você pratica alguma atividade física regularmente?

O Sim

O Não

Qual atividade física (esporte, exercício ou prática corporal) você mais pratica, e há quanto tempo? (Favor informar apenas 1 atividade- Exemplo: Tênis, há 5 anos). 


\section{APPENDIX 3- TRANSLATED AND ADAPTED SHORT QUESTIONNAIRE TO ASSESS HEALTH-ENHANCING PHYSICAL ACTIVITY (SQUASH)- WENDEL VOS ET AL. (2003)}

Para as perguntas abaixo, pense em uma semana típica dos últimos meses, e, a partir disso, selecione as alternativas que melhor indiquem quantos dias por semana fez as atividade físicas dos itens, quanto tempo (minutos e horas por dia) em média gastou e o quão intensa considerou a prática.

Para cada questão, favor responder seguindo o exemplo abaixo:

TÊNIS

Dias (POR SEMANA): 4

Tempo médio POR DIA (horas e minutos): 2 horas e 30 minutos

Esforço (leve/moderado/intenso): moderado

Lembre-se: não existem respostas "certas" ou "erradas". Também pedimos que responda da forma mais sincera, espontânea e honesta possível.

a) ATIVIDADES DE DESLOCAMENTO

Caminhando do (a) /para o trabalho ou escola:_dias por semana, tempo médio por dia (_ horas__ minutos), Esforço (lento/moderado/rápido)

Pedalando do (a)/para o trabalho ou escola:_dias por semana, tempo médio por dia horas_minutos), Esforço (lento/moderado/rápido)

b) ATIVIDADES NO TEMPO DE LAZER

Caminhada:_dias por semana, tempo médio por dia (_horas _ minutos), Esforço (lento/moderado/rápido)

Pedalando:_dias por semana, tempo médio por dia (_horas _ minutos), Esforço (lento/moderado/rápido)

Jardinagem:_dias por semana, tempo médio por dia (__ horas__minutos), Esforço (leve/moderado/intenso)

Trabalhos isolados:_dias por semana, tempo médio por dia (_ horas _ minutos), Esforço (leve/moderado/intenso)

Esportes/Exercícios/Práticas Corporais: (exemplos: tênis, exercícios em academia, yoga, natação)

$1 \_$_ dias por semana, tempo médio por dia (_horas _ minutos), Esforço (leve/moderado/intenso)

$2 \ldots$ _ dias por semana, tempo médio por dia (_horas _ minutos), Esforço (leve/moderado/intenso) 
3 (leve/moderado/intenso)

horas _ minutos), Esforço

$4 \_$_ dias por semana, tempo médio por dia (__ horas_ _minutos), Esforço (leve/moderado/intenso)

c) ATIVIDADES DOMÉSTICAS

Atividades domésticas leves (cozinhar, lavar pratos, passar roupa, cuidar de crianças):_dias por semana, tempo médio por dia (_horas __ minutos),

Atividades domésticas intensas (esfregar o chão, caminhar com sacolas de compra pesadas):_dias por semana, tempo médio por dia (_horas_minutos),

d) ATIVIDADES NO TRABALHO

Atividades leves (sentado ou em pé, com alguma caminhada, por exemplo, trabalho em escritório):_dias por semana, tempo médio por dia (_ horas _ minutos),

Atividades intensas (com frequência levanta objetos pesados no trabalho):_dias por semana, tempo médio por dia (_ horas _ minutos), 


\section{APPENDIX 4- NARCISSISTIC PERSONALITY (13 ITEMS) BY GENTILLE ET AL. (2013)}

Para cada um dos pares de características abaixo, com relação à sua personalidade, selecione a opção com a qual você MAIS CONCORDE. Lembre-se: não existem respostas "certas" ou "erradas". Também pedimos que responda da forma mais sincera, espontânea e honesta possível.

1.

O A. Eu acho que é fácil manipular as pessoas.

O B. Eu não gosto quando percebo que estou manipulando as pessoas.

2.

A. Quando as pessoas me elogiam, fico envergonhado (a).

B. Eu sei que sou uma boa pessoa porque todos me dizem isso.

3.

A. Eu gosto de mandar nas outras pessoas.

O B. Eu não me importo em seguir ordens.

4.

O A. Eu insisto em receber o respeito que mereço.

O B. Eu geralmente recebo o respeito que mereço.

5.

O A. Eu gosto de mostrar meu corpo.

O B. Eu particularmente não gosto de mostrar meu corpo.

6.

A A. Eu tenho uma forte vontade de ter poder.

O B. Ter poder sobre os outros não me interessa.

7 .

O A. Meu corpo não é nada especial.

O B. Eu gosto de olhar para o meu corpo.

8.

O A. Ser autoritário não significa muito para mim.

O B. As pessoas parecem sempre reconhecer minha autoridade.

9.

O A. Eu nunca me dou por satisfeito até conseguir tudo o que mereço.

O B. Eu me satisfaço à medida que as coisas vêm. 
10.

O A. Eu tento não me exibir.

O B. Eu normalmente me exibo quando tenho a oportunidade.

11.

A. Sou um líder nato

O B. Liderança é uma qualidade que demora muito para se desenvolver.

12.

A.Gosto de me olhar no espelho

O B. Não costumo ter interesse em ficar me olhando no espelho. 


\section{APPENDIX 5- TRANSLATED VERSION OF MOTIVATION FOR PHYSICAL ACTIVITY MEASURE- REVISED, BY RYAN ET AL. (1997)}

Considerando sua Atividade Física Principal (a que mais pratica), para cada uma das seguintes afirmações, selecione a opção que for mais verdadeira para você. Lembre-se: não existem respostas "certas" ou "erradas". Também pedimos que responda da forma mais sincera, espontânea e honesta possível, mesmo para questões que parecerem semelhantes a anterior.

\begin{tabular}{|c|c|c|c|c|c|c|c|}
\hline & $\begin{array}{l}\text { 1. Nada } \\
\text { verdadeiro } \\
\text { para mim }\end{array}$ & 2 & 3 & 4 & 5 & 6 & $\begin{array}{l}\text { 7. Muito } \\
\text { verdadeiro } \\
\text { para mim }\end{array}$ \\
\hline Faço porque quero estar em boa forma física & O & O & O & O & O & O & O \\
\hline Faço porque é divertido & O & O & $\mathrm{O}$ & $\mathrm{O}$ & O & O & O \\
\hline $\begin{array}{l}\text { Faço porque gosto de me engajar em atividades } \\
\text { que me desafiam fisicamente }\end{array}$ & O & O & O & O & O & $\mathrm{O}$ & $\mathrm{O}$ \\
\hline Faço porque quero obter novas habilidades & O & O & O & $\mathrm{O}$ & O & O & O \\
\hline $\begin{array}{l}\text { Faço porque quero perder ou manter o peso e } \\
\text { então parecer melhor }\end{array}$ & O & O & O & O & $\mathrm{O}$ & O & O \\
\hline Faço porque quero estar com meus amigos & $\mathrm{O}$ & $\mathrm{O}$ & O & O & O & O & $\mathrm{O}$ \\
\hline Faço porque gosto de praticar essa atividade & O & O & O & O & O & O & $\mathrm{O}$ \\
\hline $\begin{array}{l}\text { Faço porque quero melhorar minhas habilidades } \\
\text { atuais }\end{array}$ & O & O & O & $\mathrm{O}$ & O & O & O \\
\hline Faço porque gosto do desafio & O & O & O & $\mathrm{O}$ & O & O & O \\
\hline $\begin{array}{l}\text { Faço porque quero definir meus músculos e } \\
\text { parecer melhor }\end{array}$ & $\mathrm{O}$ & $\mathrm{O}$ & O & O & O & O & $\mathrm{O}$ \\
\hline Faço porque me faz feliz & O & O & $\mathrm{O}$ & O & O & O & $\mathrm{O}$ \\
\hline $\begin{array}{l}\text { Faço porque quero manter meu nível atual de } \\
\text { habilidade }\end{array}$ & $\mathrm{O}$ & O & O & O & O & $\mathrm{O}$ & O \\
\hline Faço porque quero ter mais energia & O & O & O & O & O & O & O \\
\hline $\begin{array}{l}\text { Faço porque gosto de atividades que desafiam } \\
\text { fisicamente }\end{array}$ & O & O & O & $\mathrm{O}$ & O & O & O \\
\hline $\begin{array}{l}\text { Faço porque gosto de estar com outras pessoas } \\
\text { que se interessam por essa atividade }\end{array}$ & $\mathrm{O}$ & O & O & $\mathrm{O}$ & O & O & $\mathrm{O}$ \\
\hline $\begin{array}{l}\text { Faço porque quero melhorar minha aptidão } \\
\text { cardiovascular }\end{array}$ & O & O & O & O & O & $\mathrm{O}$ & O \\
\hline Faço porque quero melhorar minha aparência & O & O & O & O & O & O & O \\
\hline Faço porque acho que é interessante & O & O & $\mathrm{O}$ & O & O & O & O \\
\hline $\begin{array}{l}\text { Faço porque quero melhorar minha forma física } \\
\text { para viver uma vida saudável }\end{array}$ & O & $\mathrm{O}$ & O & $\mathrm{O}$ & O & $\mathrm{O}$ & O \\
\hline Faço porque quero ser atraente para os outros & O & O & O & $\mathrm{O}$ & O & O & O \\
\hline Faço porque quero conhecer novas pessoas & $\mathrm{O}$ & O & O & $\mathrm{O}$ & O & $\mathrm{O}$ & $\mathrm{O}$ \\
\hline Faço porque curto essa atividade & O & $\mathrm{O}$ & $\mathrm{O}$ & $\mathrm{O}$ & O & $\mathrm{O}$ & $\mathrm{O}$ \\
\hline $\begin{array}{l}\text { Faço porque quero manter minha saúde física e } \\
\text { bem estar }\end{array}$ & O & O & O & O & O & O & O \\
\hline Faço porque quero melhorar minha forma física & O & O & O & $\mathrm{O}$ & O & O & O \\
\hline $\begin{array}{l}\text { Faço porque quero me aperfeiçoar na minha } \\
\text { atividade }\end{array}$ & $\mathrm{O}$ & $\mathrm{O}$ & $\mathrm{O}$ & $\mathrm{O}$ & O & $\mathrm{O}$ & $\mathrm{O}$ \\
\hline Faço porque acho essa atividade estimulante & $\mathrm{O}$ & $\mathrm{O}$ & O & $\mathrm{O}$ & O & O & O \\
\hline $\begin{array}{l}\text { Faço porque me sentirei pouco atraente } \\
\text { fisicamente se não fizer }\end{array}$ & $\mathrm{O}$ & 0 & $\mathrm{O}$ & 0 & O & $\mathrm{O}$ & $\mathrm{O}$ \\
\hline Faço porque meus amigos querem que eu faça & O & O & O & O & O & O & O \\
\hline Faço porque gosto do entusiasmo de participar & O & $\mathrm{O}$ & $\mathrm{O}$ & $\mathrm{O}$ & O & O & $\mathrm{O}$ \\
\hline $\begin{array}{l}\text { Faço porque gosto de gastar o tempo com os } \\
\text { outros fazendo essa atividade }\end{array}$ & O & O & O & O & O & $\mathrm{O}$ & O \\
\hline
\end{tabular}




\section{APPENDIX 6- SOCIOSEXUAL ORIENTATION INVENTORY- TRANSLATED VERSION, BY PENKE AND ASENDORPF (2008)}

Para cada uma das afirmações abaixo, com relação à sua vida sexual, selecione na escala a opção que for mais válida para você. Lembre-se: não existem respostas "certas" ou "erradas". Também pedimos que responda da forma mais sincera, espontânea e honesta possível.

1 Com quantos parcerios(as) diferentes você teve relações sexuais nos últimos 12 meses?

○ 0

○ 1

○ 2

○ 3

○ 4

O $5-6$

O $7-9$

O $10-19$

○ 20 ou mais

2 Com quantos parceiros(as) diferentes você já teve relação sexual em apenas uma ocasião?

○ 0

○ 1

○ 2

○ 3

○ 4

O $5-6$

O $7-9$

O $10-19$

O 20 ou mais

3 Com quantos parceiros(as) diferentes você já teve relação sexual sem ter o interesse em se comprometer em um relacionamento de longo prazo com essa pessoa?

○ 0

○ 1

○ 2

○ 3

○ 4

O 5-6

O 7-9

O $10-19$

○ 20 ou mais 
Para cada uma das afirmações abaixo, indique de 1 (discordo completamente) a 9 (concordo completamente) o quanto são válidas para você

$4 \ldots$ Por mim está tudo bem em fazer sexo sem amor.

5 Eu Eu consigo me imaginar confortável e aproveitando sexo "casual" com diferentes parceiros (as).

6 ___ Eu prefiro não fazer sexo com alguém até eu estar certo(a) que nós vamos ter um relacionamento sério de longo prazo.

7 Com que frequência você fantasia em ter relações sexuais com alguém o(a) qual você não está(ava) comprometido(a) em uma relação amorosa?

O Nunca

O 1 vez por mês

O Algumas vezes por semana

O Muito raramente

O 1 vez a cada 2 semanas

O Quase todos os dias

O 1 vez a cada 2 ou 3 meses

O 1 vez por semana

O 1 vez por dia

8 No dia-a-dia, com que frequência você tem fantasias espontâneas sobre fazer sexo com alguém que você acabou de conhecer?

O Nunca

O 1 vez por mês

O Algumas vezes por semana

O Muito raramente

O 1 vez a cada 2 semanas

O Quase todos os dias

O 1 vez a cada 2 ou 3 meses

O 1 vez por semana

O 1 vez por dia 


\section{APPENDIX 7- BRAZILIAN VERSION OF ROSENBERG'S SELF- ESTEEM SCALE (SBICIGO, BANDEIRA \&DELL'AGLIO, 2010)}

Para cada uma das afirmações abaixo, com relação à sua personalidade, selecione na escala a opção que for mais válida para você: Lembre-se: não existem respostas "certas" ou "erradas". Também pedimos que responda da forma mais sincera, espontânea e honesta possível.

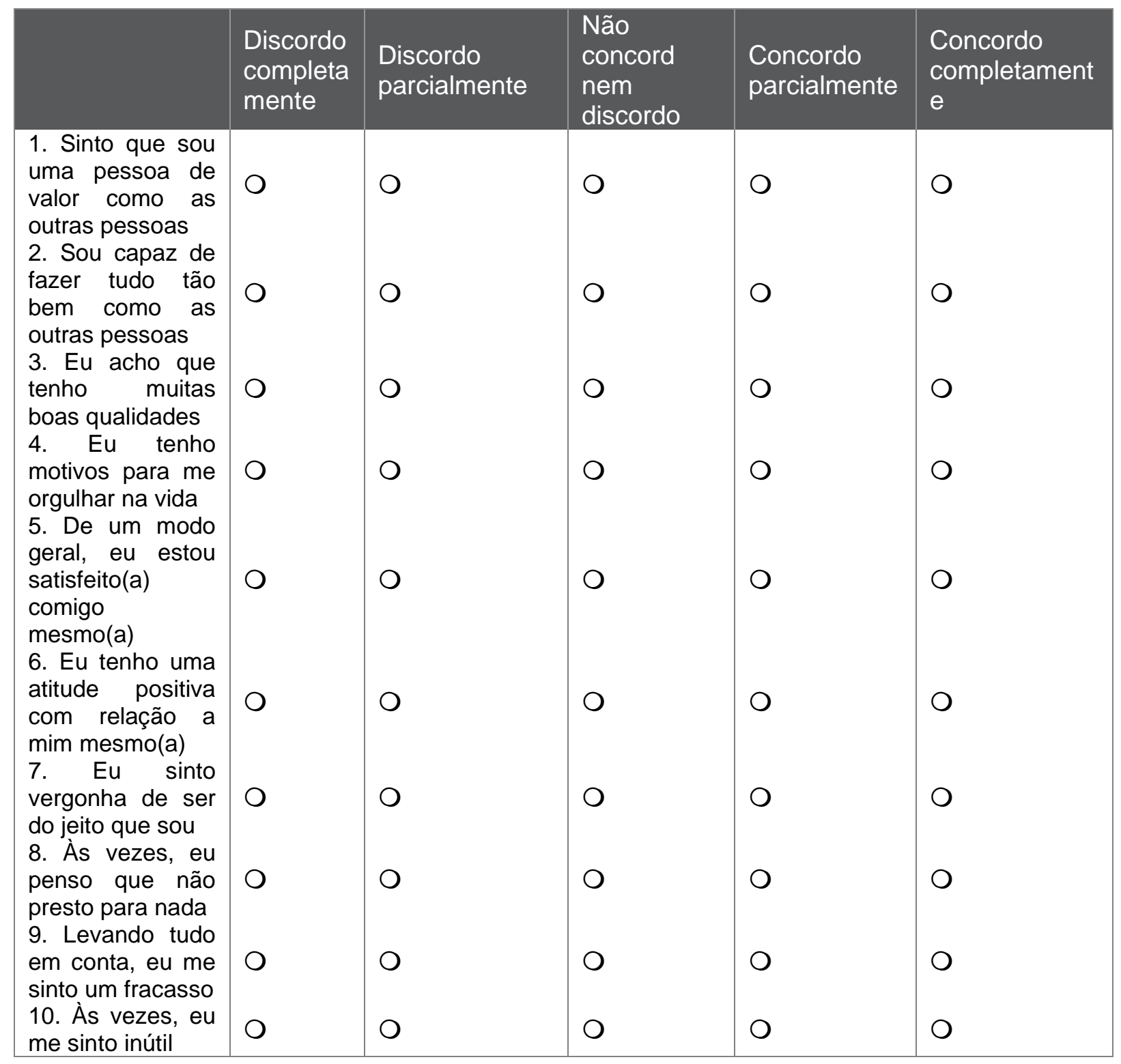




\section{APPENDIX 8- REDUCED SCALE OF PERSONALITY DESCRIPTORS (RED5) BY NATIVIDADE \& HULTZ (2015)}

Para cada uma das afirmações abaixo, com relação à sua personalidade, selecione na escala a opção que for mais válida para você: Lembre-se: não existem respostas "certas" ou "erradas". Também pedimos que responda da forma mais sincera, espontânea e honesta possível.

\begin{tabular}{|c|c|c|c|c|c|c|c|}
\hline & $\begin{array}{l}\text { 1. Discordo } \\
\text { completamente }\end{array}$ & 2 & 3 & $\begin{array}{l}\text { 4. Não concord nem } \\
\text { discordo }\end{array}$ & 5 & 6 & $\begin{array}{l}\text { 7. Concordo } \\
\text { completamente }\end{array}$ \\
\hline $\begin{array}{l}\text { 1. Sou uma pessoa que não } \\
\text { gosta de mudancas }\end{array}$ & O & 0 & O & O & O & O & O \\
\hline $\begin{array}{l}\text { 2. Sou uma pessoa } \\
\text { ansiosa }(0)\end{array}$ & O & 0 & O & 0 & O & 0 & 0 \\
\hline $\begin{array}{l}\text { 3. Sou uma pessoa pouco } \\
\text { amigável }\end{array}$ & O & 0 & O & O & O & O & $\mathrm{O}$ \\
\hline $\begin{array}{l}\text { 4. Sou uma pessoa } \\
\text { extrovertida(o) }\end{array}$ & $\mathrm{O}$ & O & $\mathrm{O}$ & O & O & O & O \\
\hline $\begin{array}{l}\text { 5. Sou uma pessoa } \\
\text { indisciplinada }(0)\end{array}$ & O & 0 & O & 0 & O & O & 0 \\
\hline $\begin{array}{l}\text { 6. Sou uma pessoa } \\
\text { simpática(o) }\end{array}$ & O & O & O & O & O & O & O \\
\hline $\begin{array}{l}\text { 7. Sou uma pessoa } \\
\text { convencional }\end{array}$ & $\mathrm{O}$ & O & O & $\mathrm{O}$ & O & O & $\mathrm{O}$ \\
\hline $\begin{array}{l}\text { 8. Sou uma pessoa } \\
\text { responsável }\end{array}$ & O & O & O & O & O & O & $\mathrm{O}$ \\
\hline $\begin{array}{l}\text { 9. Sou uma pessoa } \\
\text { tranquila(o) }\end{array}$ & o & 0 & 0 & 0 & 0 & O & 0 \\
\hline $\begin{array}{l}\text { 10. Sou uma pessoa } \\
\text { comunicativa(o) }\end{array}$ & O & O & 0 & O & 0 & O & O \\
\hline $\begin{array}{l}\text { 11. Sou uma pessoa } \\
\text { desorganizada(o) }\end{array}$ & 0 & 0 & 0 & 0 & O & 0 & 0 \\
\hline $\begin{array}{l}\text { 12. Sou uma pessoa que } \\
\text { tem curiosidade }\end{array}$ & O & 0 & 0 & 0 & 0 & 0 & 0 \\
\hline $\begin{array}{l}\text { 13. Sou uma pessoa } \\
\text { antipática(o) }\end{array}$ & O & O & $\mathrm{O}$ & O & O & O & $\mathrm{O}$ \\
\hline $\begin{array}{l}\text { 14. Sou uma pessoa } \\
\text { temperamental }\end{array}$ & O & O & O & O & O & O & O \\
\hline $\begin{array}{l}\text { 15. Sou uma pessoa } \\
\text { tímida(o) }\end{array}$ & 0 & 0 & 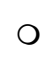 & 0 & 0 & 0 & 0 \\
\hline $\begin{array}{l}\text { 16. Sou uma pessoa } \\
\text { esforçada(o) }\end{array}$ & O & O & O & O & O & O & $\mathrm{O}$ \\
\hline $\begin{array}{l}\text { 17. Sou uma pessoa } \\
\text { emocionalmente estável }\end{array}$ & O & O & $\mathrm{O}$ & O & O & O & O \\
\hline $\begin{array}{l}\text { 18. Sou uma pessoa } \\
\text { amigável }\end{array}$ & O & O & 0 & O & O & 0 & O \\
\hline $\begin{array}{l}\text { 19. Sou uma pessoa } \\
\text { calada(o) }\end{array}$ & O & 0 & O & 0 & 0 & O & 0 \\
\hline $\begin{array}{lcc}20 . \quad \text { Sou uma } & \text { pessoa } \\
\text { aberta(o) } & \text { a } & \text { novas } \\
\text { experiências } & & \\
\end{array}$ & 0 & 0 & 0 & 0 & 0 & 0 & 0 \\
\hline
\end{tabular}

End message: Muito obrigado pela participação! Caso queira receber os resultados do estudo, favor entrar em contato com: rafael.hsu@usp.br 